\title{
Ecotoxicological aspects related to the presence of pharmaceuticals in the aquatic environment
}

Lúcia H.M.L.M. Santos, A.N. Araújo, Adriano Fachini, A. Pena, C. Delerue-Matos, M.C.B.S.M. Montenegro

\section{ABSTRACT}

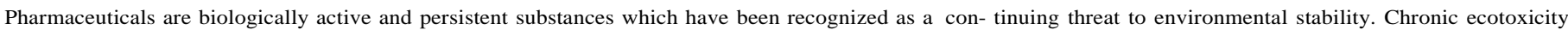

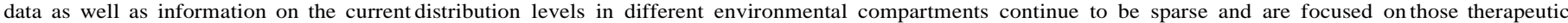

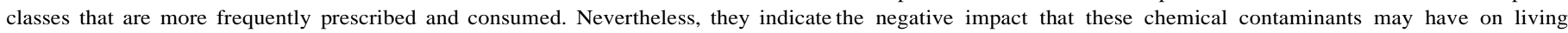

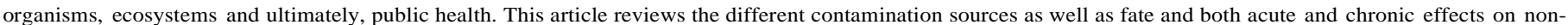
target organisms. An extensive review of existing data in the form of tables, encompassing many therapeutic classes is presented. 


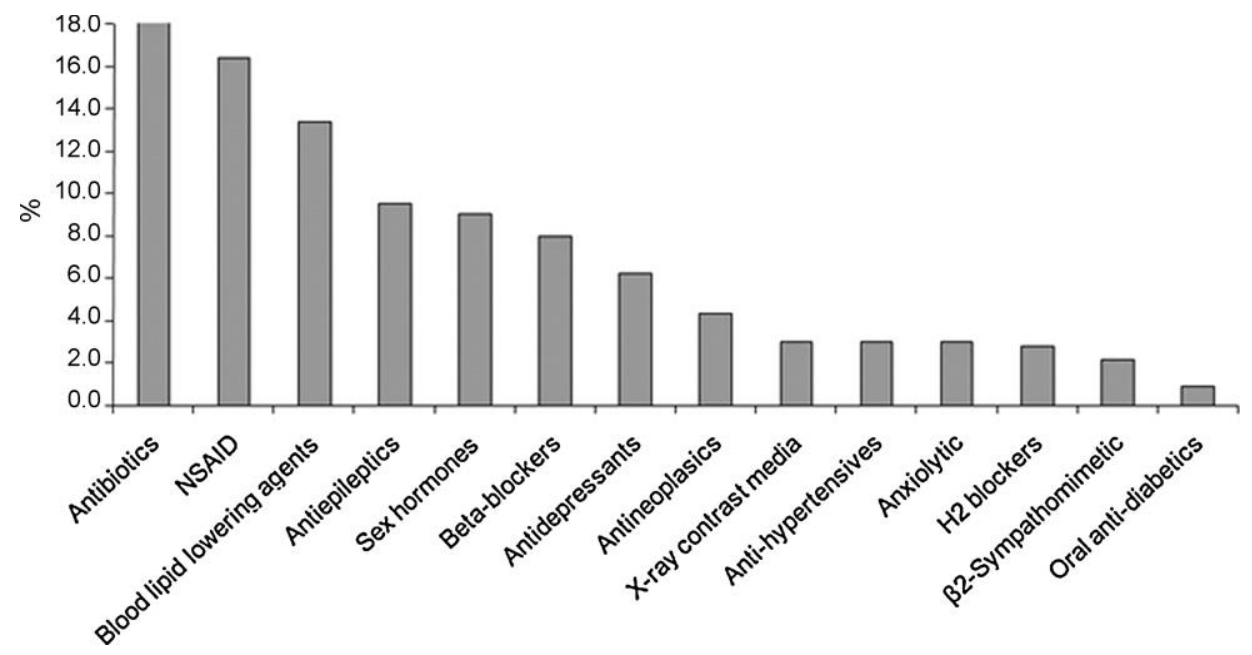

Fig. 1. Percentage of published studies on different therapeutic classes, expressed in relative percentage, described on 183 articles published between 1996 and 2009.

\section{Introduction}

The presence of medicines in the environment has become a recent research topic. Initially, the problem was highlighted in the US back in the 1970s [1,2] and almost a decade later in Eng- land (UK) [3-5]. Yet, it was only in the mid 90s with advances in analytical techniques that important knowledge on environmental contamination by those compounds grew. Powerful hyphenated chromatographic-detection techniques enabling detection limits within the $\mathrm{n} \mathrm{L}^{-1}$ to $\mu \mathrm{g} \mathrm{L}^{-1}$ range allowed researchers to quantify a large number of medicines components (i.e. drugs and excipients) in the environment, thus compelling the scientific community to consider this contamination type as a potential issue meriting con- cern [6-8]. In fact, tons of them are produced annually worldwide to be consumed by humans or animals $[9,10]$. They are conceived primarily to have particular physiological modes of action and fre- quently to resist to inactivation before exerting their intended therapeutic effect. However, these same properties are paradox-ically responsible either for bioaccumulation and toxic effects in aquatic and terrestrial ecosystems $[10,11]$. In a different way from some conventional pollutants (such as pesticides, detergents, fuels, among others), medicines are continuously delivered at low levels which might give rise to toxicity even without high persistence rates [11-13]. Wide dissemination at low concentrations mainly in the aquatic environment is evident today. Such concentrations have been detected in aquatic compartments such as influents [14-16] and effluents [17-19] from sewage treatment plants (STPs), surface waters (rivers, lakes, streams, estuaries, among others) [20-24], seawater [25], groundwater [26-28] and drinking water [29-32]. The scientific community is in broad agreement with the possibility that adverse effects may arise from the presence of pharmaceu- ticals not only for human health but also for aquatic organisms. Several, almost negligible effects have been shown to occur from continuous exposure during the life cycle of aquatic vertebrates and invertebrates to sub-therapeutic drug concentrations [33,34]. These effects slowly accumulate to manifest themselves into a final irreversible condition which is frequently only noticed sev- eral generations' later, affecting sustainability of aquatic organisms' populations [35].

This review presents an updated survey of the acquired knowl- edge regarding the sources, spreading conditions, occurrence and induced toxic effects on non-target organisms by drugs in the envi- ronment. Fig. 1 illustrates the clear predominance of studies on non-steroidal antiinflammatory drugs (NSAIDs), antibiotics and

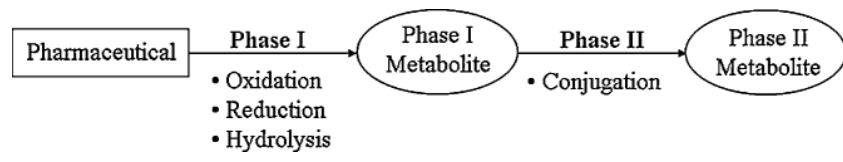

Fig. 2. Schematic representation of pharmaceutical biotransformation to increase their polarity (adapted from Reference [35]).

blood lipid lowering agents from the literature, drawn from human prescription and consumption. Most of the reported data concerns the occurrence of drugs of each therapeutic class in the aquatic environment and is included in the form of tables to facilitate easy comparison between regional sample sources and ecotoxicologi- cal data. Current EU and US legislation compels new medicines to undergo an environmental impact assessment and consequently, new evaluation methods for acute as well as chronic effects are being implemented. However, a significant lack of knowledge per- sists particularly concerning toxicological data from synergistic pharmaceuticals interactions.

\section{Sources of environmental contamination}

The most obvious pathway for environmental contamination of medicines is via the unaltered excretion in urine and faeces although other anthropogenic mechanisms should be assumed, namely:

a) Metabolism post-consumption; since many drugs are metabolised as the organism attempts to convert hydrophobic compounds into more easily excreted polar residues. Their bio- conversion into one or more metabolites can occur throughout Phase $\mathrm{I}^{1}$ and Phase $\mathrm{II}^{2}$ reactions as shown in Fig. 2 [36].

b) Diagnostic compounds; such as X-ray contrast media are directly discharged in their native forms.

c) Household Disposal; either topic formulations or unused medicines (out-of-date or unwanted) are discarded through the sink/toilet or via waste collection $[9,37,38]$, before being taken to

\footnotetext{
${ }^{1}$ Phase I reactions include oxidation, reduction and hydrolysis to modify the orig- inal molecule structure by introducing functional groups more receptive to phase II reactions.

2 Phase II reactions (or conjugation reactions) consist of the addition of endogenous groups (like glucuronic acid, sulphate, glutathione, etc.) to receptive functional groups present in the original molecule or in its metabolite derived from phase I.
} 


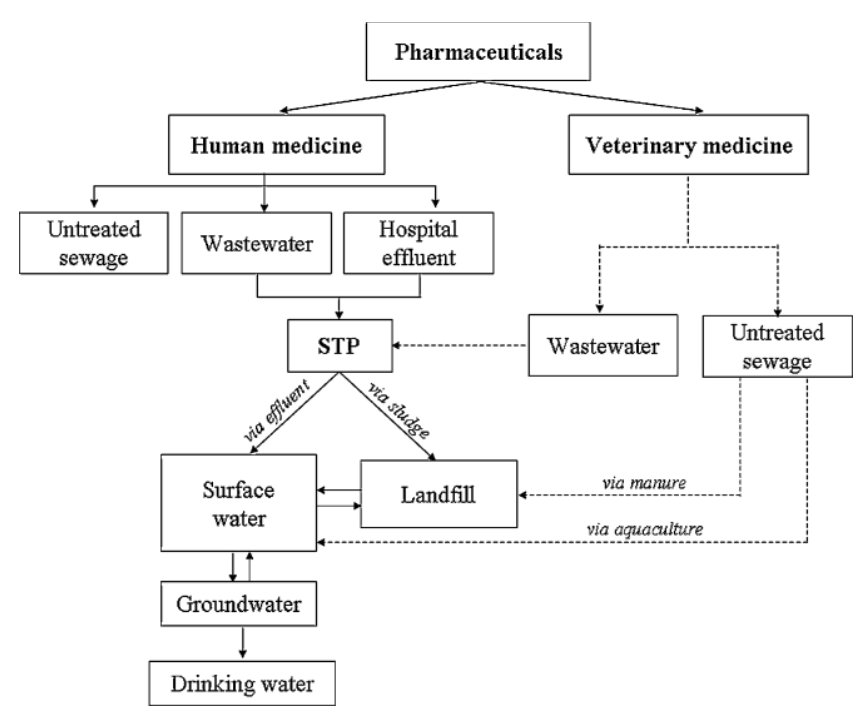

Fig. 3. Representative sources and fate of pharmaceuticals in the environment (adapted from Reference [6]).

landfill sites where they appear as terrestrial ecosystem contaminants. Alternatively, they may possibly leak into surrounding water compartments $[39,40]$.

d) Impacts due to anthropogenic activities; as, for instance, Sewage Treatment Plant (STP) sludge, which can carry non-suspected drugs and is frequently used as a fertilizer on agricultural land [41,42]; veterinary medicines, which are also excreted in urine and faeces by animals before being spread onto land via manure application as fertilisers. Apart from the potential for direct soil contamination, there is also the risk of run-off with heavy rain, thus potentially contaminating both the surround- ing surface and groundwater [42-44]. Other example of an anthropogenic activity is aquaculture, whose pharmaceuticals employed, as well as their metabolites and degradation prod- ucts, are directly discharged into surface waters $[45,46]$. Another important source of environmental contamination by pharma- ceuticals is the effluents of pharmaceutical production facilities [47-49].

At a higher level, existing geographical information on environmental contamination sources is sparse and limited. Countries and regions worldwide differ concerning the prevalence of diseases, waste treatment processes, cultural habits or economic constraints related to the pharmaceutical market [8]. Nevertheless, it seems that urban regions are major sources of contamination due to the proximity of hospitals and STP facilities. Additionally, the contri- bution of rural regions where agriculture, animal husbandry and aquaculture represent important ways of life should be considered as important.

\section{Environmental fate}

The fate and behaviour of medicines in the environment still requires further elucidation. As previously stated, drugs (used in human and/or in veterinary medicine) and their metabolites are spread into the environment in different ways, namely through STP effluents, heavy rain on agricultural land provokes (surface) water run-off, and occasionally, through untreated sewage (domes- tic wastes and flooding, among others) (Fig. 3). Some of them doreach surface waters (rivers, lakes and estuaries, among others) and eventually groundwaters $[11,35,39]$ after resisting the intended biological degradation. However, in surface waters they may be degraded through different processes such as photolysis whose efficiency depends on factors such as intensity of solar irradiation, latitude, season of the year and presence of photosensitizes (e.g. nitrates, humic acids) [50,51].

In the case of drugs that have low volatility and high polarity distribution is mainly made by aqueous transport or even via food chain dispersion [35,52]. Usually, wastewaters are conducted to STPs, which play a key role in the entrance of pharmaceuticals in the environment. However, in some regions or even countries these kinds of facilities may not exist and the environmental problem is still worse. The evaluation of removal efficiency in STPs (by com- paring influent and effluent contents) has been studied in detail, showing removal rates that can differ by up to $99 \%$ [22,53-55]. Depending both on the particular technology resorted to and the active substance properties they may undergo: (i) degradation (mineralization) to low molecular weight compounds (e.g. $\mathrm{CO}_{2}$ and water); (ii) entrapment by suspended solids; (iii) discharge of the parent compound through chemical cleavage of the respective con- jugate forms and (iv) conversion to a more hydrophilic, persistent form which will short-circuit the treatment process $[39,41,56,57]$. Thus, in hospitals use of specific antibiotics, antineoplasic or diag- nostic agents subsequently requires a sewage treatment process more embracing and directed to these kind of drugs, which are only used in hospitals [35,58], and that must be different to the more specific procedure adopted at STPs receiving industrial discharges from drug manufactures [47-49,59]. In both, the form and extension of the final contamination risk will also depend on geographical location of the STP facility. Low adsorption coefficients that make active substances remain in the aqueous phase, favour their mobility through the STP and into nearby surface waters [53]. Adsorption to suspended solids depending on both hydropho- bic and electrostatic interactions established between each will follow the same destiny $[11,41]$. On the other hand, hydropho- bic metabolites will be held on STP sludge, provoking terrestrial contamination, thus affecting microorganisms and invertebrates. Aerobic/anaerobic bioconversion occurring either during sewage sludge digestion or during activated sludge treatment seems to be the most efficient process to eliminate chemical contaminants from the aquatic environment. Usually, the best biodegradation results are obtained when activated sludge treatment is conducted through an increase in hydraulic retention time and the use of mature sludge [10]. However, one should be aware of the fact that if a particular pharmaceutical is not detected in a STP effluent, this does not imply that it has been fully removed. On some occasions, it may have been degraded and give rise to unsuspecting metabo- lites that will subsequently contaminate surface waters $[35,39,60]$. Notwithstanding that some drugs and their metabolites show a stable nature, nowadays is still difficult to establish a complete contamination pattern in final receiving surface waters, due to the water dilution, the treatment and discharging processes [54].

\section{Ecotoxicology}

Continuous consumption of drugs even at sub-therapeutic concentrations represents a potential threat to public health although one should bear in mind that it is still impossible to evaluate the effects of exposure on human health $[35,60,61]$. In turn, many non-target organisms (which possess human- and animal-alike metabolic pathways, similar receptors or biomolecules) are there- fore inadvertently exposed to active substances released into the environment $[10,35]$. A comprehensive manner to evaluate the toxicity effects on non-target organisms must include the devel- opment of specific tests embracing either acute effects (where mortality rates are often registered) or chronic effects (by means of exposure to different concentrations of a chemical compound over a prolonged period of time). In the latter, effects are measured 

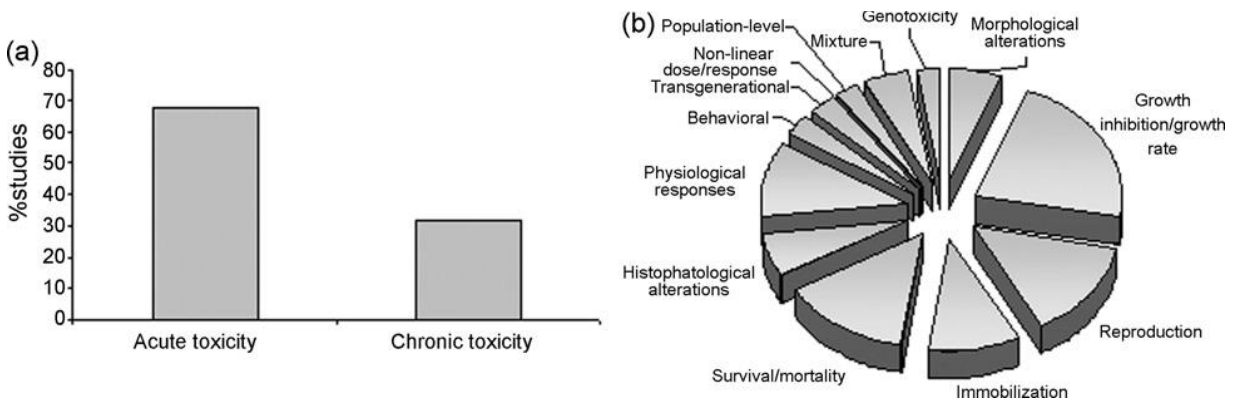

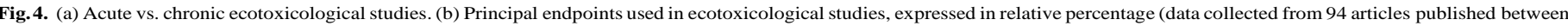
1996 and 2009).

through specific parameters such as growth index or reproduc- tion rates [52]. Unfortunately, studies on acute effects in organisms belonging to different trophic levels (i.e. algae, zooplankton and other invertebrates and fish) predominate relatively to chronic ones (Fig. 4). Acute toxicity data is only valuable when accidental discharge of the drugs occurs, since the environmental concen- trations usually reported for these compounds are low, typically in a factor of one thousand. Bioaccumulation and chronic toxicity tests are scarce [10,35] probably due to the complex experimental work involved. However, recent development of sensitive meth- ods for identification and quantification of drugs enabled to devise their distribution patterns in several environmental samples, thus highlighting the more relevant therapeutic classes in terms of envi- ronmental contamination (Fig. 5). These data is useful to set out the most appropriate active substances to be used in ecotoxicity tests. According to data present in literature, scientific community has mainly concerned their attention on therapeutic classes such as, non-steroidal anti-inflammatory drugs, blood lipid lowering agents, antibiotics and sex hormones. By those reasons, this review will focus in the drugs belonging to those therapeutic classes.

Within this context, some of the acute and chronic toxicity effects caused by drugs belonging to different therapeutic classes and mixtures of them in non-targets organisms deserve further analysis and are discussed in the following section. For a critical analysis of the ecotoxicological data present in the literature rel- atively to different drugs, we decide to group them according to their main pharmacological activity. Therefore, toxicity data will be related to the environmental concentrations found by several authors, to establish the severity of the situation.

\subsection{Non-steroidal anti-inflammatory drugs}

Non-steroidal anti-inflammatory drugs are weak acids acting by reversible or irreversible inhibition of one or both isoforms of the cyclooxygenase enzymes, COX-1 and COX-2, involved in the synthesis of different prostaglandins from arachidonic acid [62]. A cyclooxygenase enzyme similar to human COX-2 has been found in fish thereby making them a potential target for aquatic contamina- tion [63]. Prostaglandins also play an important role in the synthesis of bird eggshells and from inhibiting its synthesis, shell thinning has been observed [64]. Among the NSAID, diclofenac showed the most acute toxic nature with effects being observed at concentrations below $100 \mathrm{mg} \mathrm{L}^{-1}$ [65]. Chronic toxicity trials performed on rain- bow trout (Oncorhynchus mykiss) evidenced cytological changes in the liver, kidneys and gills after 28 days of exposure to just $1 \mu \mathrm{g} \mathrm{L}^{-1}$ of diclofenac. For a concentration of $5 \mu \mathrm{g} \mathrm{L}^{-1}$ renal lesions were evident as well as drug bioaccumulation in the liver, kid- neys, gills and muscle [66,67]. Brown trout (Salmo trutta f. fario) showed similar cytological damage and a reduction of haematocrit values after 21 days of exposure to $0.5 \mu \mathrm{g}$ $\mathrm{L}^{-1}$ of this active sub- stance [68]. Schmitt-Jansen et al. [69] evaluated both diclofenac phytotoxicity and its photochemical products on the unicellular chlorophyte Scenedesmus vacuolatus. Inhibition of algal reproduc- tion by the parent compound only occurred at a concentration of $23 \mathrm{mg} \mathrm{L}^{-1}$, hence indicating no specific toxicity. However, the threat significantly increased when metabolites were produced from $53 \mathrm{~h}$ of exposure to daylight. Diclofenac also inhibited the growth of marine phytoplankton Dunaliella tertiolecta for concentrations of $25 \mathrm{mg} \mathrm{L}^{-1}$ and above [70]. For this organism, $96 \mathrm{~h} \mathrm{EC}_{50}$ of

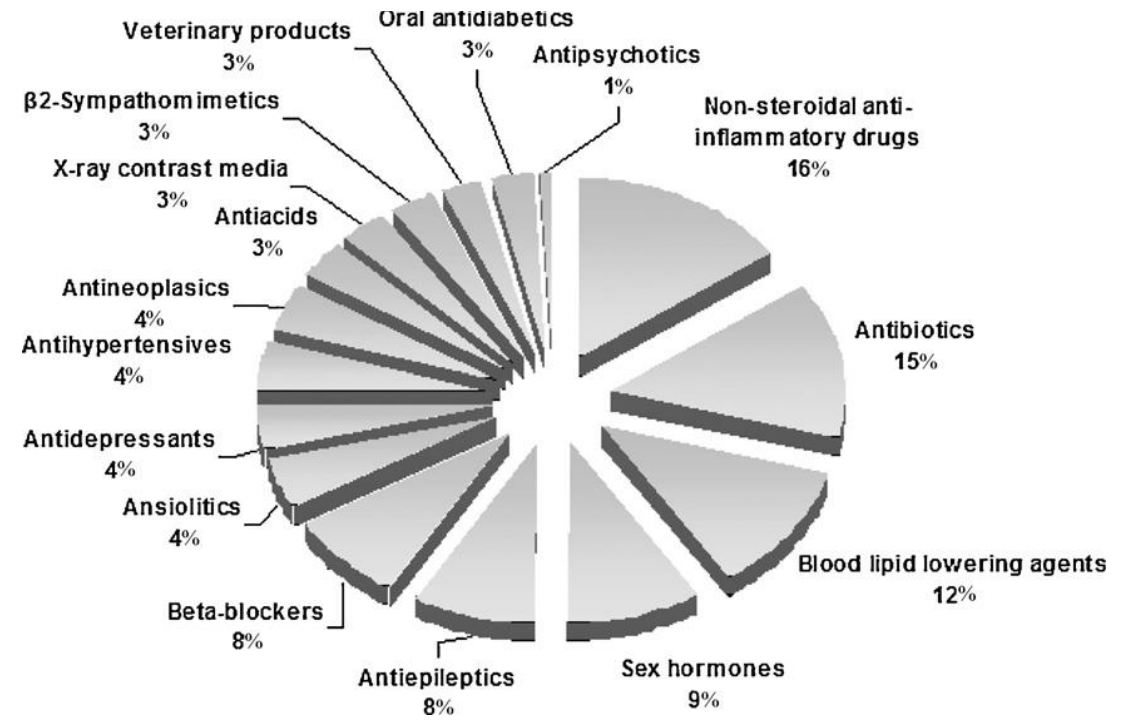

Fig. 5. Therapeutic classes detected in the environment, expressed in relative percentage. Data collected from 134 articles published between 1997 and 2009. 
Table 1

\begin{tabular}{|c|c|c|c|c|c|c|c|c|c|c|c|c|}
\hline Compound & CAS number & Sample & Country & $\begin{array}{l}\text { Analytical } \\
\text { procedure }\end{array}$ & $\operatorname{LOD}\left(\mathrm{ngL}^{-1}\right)$ & $\begin{array}{l}\text { Concentration } \\
\text { reported }\left(\mathrm{ngL}^{-1}\right)\end{array}$ & Ref. & Taxon & Species & $\begin{array}{l}\text { Toxicological } \\
\text { endpoint }\end{array}$ & $\begin{array}{l}\text { Ecotoxicity } \\
\text { data }\end{array}$ & Ref. \\
\hline Acetylsalicylic acid & $50-78-2$ & $\begin{array}{l}\text { Somes river } \\
\text { water }\end{array}$ & Romania & SPE-GC-MS & 30 (LOQ) & $<30-37.2( \pm 4.6)$ & [20] & Algae & D. subspicatus & $\begin{array}{l}\mathrm{EC}_{50} \text { (growth } \\
\text { inhibition) }\end{array}$ & $106.7 \mathrm{mg} \mathrm{L}^{-1}$ & [95] \\
\hline \multirow[t]{2}{*}{ Acetylsalicylic acid } & & STP influent & Japan & SPE-GC-MS & 10 (LOQ) & $470-19,400$ & [86] & Crustacean & D. magna & $\begin{array}{l}\mathrm{EC}_{50}(48 \mathrm{~h}) \\
\text { (immobilization) }\end{array}$ & $88.1 \mathrm{mgL}^{-1}$ & [95] \\
\hline & & STPeffluent & & & & $38.0-111$ & & & & & & \\
\hline \multirow[t]{3}{*}{ Salicylic acid } & 69-72-7 & STPeffluent & Canada & SPE-GC-MS/MS & 0.1 & $554.3-2178.2$ & {$[17]$} & Bacteria & V. fischeri & $\mathrm{EC}_{50}(30 \mathrm{~min})$ & $90 \mathrm{mgL}^{-1}$ & [83] \\
\hline & & River water & & & & $130.4-371.5$ & & & & & & \\
\hline & & Lake water & & & & 286.7 & & & & & & \\
\hline \multirow[t]{5}{*}{ Salicylic acid } & & STP influent & Canada & SPE-GC-MS & 10 & $2820-12,700$ & {$[18]$} & Algae & $\begin{array}{l}\text { Scenedesmus } \\
\text { subspicatus }\end{array}$ & $\mathrm{EC}_{50}(72 \mathrm{~h})$ & $>100 \mathrm{mg} \mathrm{L}^{-1}$ & [83] \\
\hline & & STPeffluent & & & & $10-320$ & & & & & & \\
\hline & & & & & & & & Crustacean & D. magna & $\begin{array}{l}\mathrm{EC}_{50}(24 \mathrm{~h}) \\
\text { (immobilization) }\end{array}$ & $118 \mathrm{mgL}^{-1}$ & [83] \\
\hline & & & & & & & & Ciliates & $\begin{array}{l}\text { Tetrahymena } \\
\text { pyriformis }\end{array}$ & $\begin{array}{l}\mathrm{EC}_{50}(48 \mathrm{~h}) \text { (growth } \\
\text { inhibition) }\end{array}$ & $>100 \mathrm{mg} \mathrm{L}^{-1}$ & [83] \\
\hline & & & & & & & & Fish & $\begin{array}{l}\text { B. rerio (zebra } \\
\text { fish) }\end{array}$ & $\mathrm{LC}_{50}(48 \mathrm{~h})$ & $37 \mathrm{mgL}^{-1}$ & [83] \\
\hline \multirow[t]{2}{*}{ Diclofenac } & $15307-79-6$ & STP influent & Spain & SPE-GC-MS & 100 & $200-3600$ & {$[14]$} & Crustacean & D. magna & $\begin{array}{l}\mathrm{EC}_{50}(48 \mathrm{~h}) \\
\text { (immobilization) }\end{array}$ & $68 \mathrm{mgL}^{-1}$ & [65] \\
\hline & & STPeffluent & & & & $140-2200$ & & & & & & \\
\hline \multirow[t]{2}{*}{ Diclofenac } & & STP influent & Switzerland & SPE-GC-MS & 6 & $1300-2900$ & {$[15]$} & Algae & D. subspicatus & $\begin{array}{l}\mathrm{EC}_{50} \text { (growth } \\
\text { inhibition) }\end{array}$ & $72 \mathrm{mgL}^{-1}$ & [65] \\
\hline & & STPeffluent & & & & $1300-2400$ & & & & & & \\
\hline Diclofenac & & STP effluent & Canada & SPE-GC-MS/MS & 1.0 & $32-448$ & [17] & Duckweed & L. minor & $\begin{array}{l}\mathrm{EC}_{50}(7 \mathrm{~d}) \text { (growth } \\
\text { inhibition) }\end{array}$ & $7.5 \mathrm{mgL}^{-1}$ & [65] \\
\hline \multirow[t]{2}{*}{ Diclofenac } & & STP influent & Canada & SPE-GC-MS & 10 & $50-2450$ & [18] & Fish & $\begin{array}{l}\text { Oncorhynchus } \\
\text { mykiss }\end{array}$ & $\begin{array}{l}\text { LOEC ( } 28 \text { days) } \\
\text { (histopathological } \\
\text { alterations) }\end{array}$ & $5 \mu \mathrm{gL}^{-1}$ & [66] \\
\hline & & STPeffluent & & & & $70-250$ & & & & & & \\
\hline \multirow[t]{2}{*}{ Diclofenac } & & STP influent & Greece & SPE-GC-MS & 1 & $12-560$ & [19] & Fish & $\begin{array}{l}\text { Oncorhynchus } \\
\text { mykiss }\end{array}$ & $\begin{array}{l}\text { LOEC ( } 28 \text { days) } \\
\text { (cytological } \\
\text { alterations) }\end{array}$ & $1 \mu \mathrm{gL}^{-1}$ & [67] \\
\hline & & STPeffluent & & & & $10-365$ & & & & & & \\
\hline \multirow[t]{3}{*}{ Diclofenac } & & STP influent & Sweden & SPE-GC-MS & $-\dot{t}$ & 160 & [21] & Fish & $\begin{array}{l}\text { Salmo trout } \mathrm{f} . \\
\text { fario }\end{array}$ & $\begin{array}{l}\text { NOEC ( } 21 \text { days) } \\
\text { (histopathological } \\
\text { alterations) }\end{array}$ & $0.5 \mu \mathrm{gL}^{-1}$ & [68] \\
\hline & & STPeffluent & & & & 120 & & & & & & \\
\hline & & $\begin{array}{l}\text { Höje river } \\
\text { water }\end{array}$ & & & & $10-120$ & & & & & & \\
\hline Diclofenac & & $\begin{array}{l}\text { Paraíba do } \\
\text { Sul river } \\
\text { water } \\
\text { Drinking } \\
\text { water }\end{array}$ & Brazil & SPE-GC-MS & 10 & $20-60$ & [22] & Algae & $\begin{array}{l}\text { Dunaliella } \\
\text { tertiolecta }\end{array}$ & $\begin{array}{l}\mathrm{EC}_{50}(96 \mathrm{~h}) \text { (growth } \\
\text { inhibition) }\end{array}$ & $185,690 \mu \mathrm{gL}^{-1}$ & [87] \\
\hline \multirow[t]{3}{*}{ Diclofenac } & & Groundwater & Germany & SPE-GC-MS & 29 & $\begin{array}{l}<10-50 \\
590\end{array}$ & {$[26]$} & Algae & D. subspicatus & $\begin{array}{l}\mathrm{EC}_{50} \text { (growth } \\
\text { inhibition) }\end{array}$ & $71.9 \mathrm{mgL}^{-1}$ & [95] \\
\hline & & & & & & & & Crustacean & D. magna & $\begin{array}{l}\mathrm{EC}_{50}(48 \mathrm{~h}) \\
\text { (immobilization) }\end{array}$ & $68.0 \mathrm{mg} \mathrm{L}^{-1}$ & [95] \\
\hline & & & & & & & & Bacteria & V. fischeri & $\mathrm{EC}_{50}(30 \mathrm{~min})$ & $11,454 \mu \mathrm{gL}^{-1}$ & [96] \\
\hline Diclofenac & & $\begin{array}{l}\text { Drinking } \\
\text { water }\end{array}$ & USA & SPE-LC-MS/MS & 0.25 & $<0.25$ & [32] & Algae & P. subcapitata & $\begin{array}{l}\text { NOEC (96h) (growth } \\
\text { inhibition) }\end{array}$ & $10,000 \mu \mathrm{g} \mathrm{L}^{-1}$ & [96] \\
\hline Diclofenac & & $\begin{array}{l}\text { Hospital } \\
\text { effluent }\end{array}$ & Taiwan & $\begin{array}{l}\text { SPE- } \\
\text { HPLC-MS/MS }\end{array}$ & 10 & 328 & [47] & & & $\begin{array}{l}\text { LOEC }(96 \mathrm{~h}) \text { (growth } \\
\text { inhibition) }\end{array}$ & $20,000 \mu \mathrm{g} \mathrm{L}^{-1}$ & [96] \\
\hline
\end{tabular}




\begin{tabular}{|c|c|c|c|c|c|c|c|c|c|c|c|c|}
\hline Compound & CAS number & Sample & Country & $\begin{array}{l}\text { Analytical } \\
\text { procedure }\end{array}$ & $\operatorname{LOD}\left(\mathrm{ngL}^{-1}\right)$ & $\begin{array}{l}\text { Concentration } \\
\text { reported }\left(\mathrm{ngL}^{-1}\right)\end{array}$ & Ref. & Taxon & Species & $\begin{array}{l}\text { Toxicological } \\
\text { endpoint }\end{array}$ & $\begin{array}{l}\text { Ecotoxicity } \\
\text { data }\end{array}$ & Ref. \\
\hline & & $\begin{array}{l}\text { Pharmaceutical } \\
\text { production } \\
\text { facility } \\
\text { effluent }\end{array}$ & & & & 53 & & & & & & \\
\hline \multirow[t]{2}{*}{ Diclofenac } & & STP influent & United Kingdom & $\begin{array}{l}\text { SPE- } \\
\text { HPLC-MS/MS }\end{array}$ & 20 & 901-1036 & [53] & Crustacean & D. magna & $\begin{array}{l}\mathrm{EC}_{50}(48 \mathrm{~h}) \\
\text { (immobilization) }\end{array}$ & $22,430 \mu \mathrm{g} \mathrm{L}^{-1}$ & [96] \\
\hline & & STPeffluent & & & & $261-598$ & & & & & & \\
\hline \multirow[t]{4}{*}{ Diclofenac } & & STP influent & Spain & $\begin{array}{l}\text { SPE- } \\
\text { HPLC-MS/MS }\end{array}$ & 7 & $21-148$ & [71] & & C. dubia & $\begin{array}{l}\mathrm{EC}_{50}(48 \mathrm{~h}) \\
\text { (immobilization) }\end{array}$ & $22,704 \mu \mathrm{gL}^{-1}$ & [96] \\
\hline & & STPeffluent & Belgium & & & $32-1420$ & & & & & & \\
\hline & & River water & Germany & & & $26-72$ & & & & & & \\
\hline & & $\begin{array}{l}\text { Drinking } \\
\text { water }\end{array}$ & Slovenia & & & $<7$ & & & & & & \\
\hline \multirow[t]{2}{*}{ Diclofenac } & & $\begin{array}{l}\text { Elber river } \\
\text { water Alster } \\
\text { lake water }\end{array}$ & Germany & SPE-GC-MS & $0.08(\mathrm{LOQ})$ & $42-67$ & [72] & & & $\begin{array}{l}\text { NOEC (7d) } \\
\text { (reproduction) }\end{array}$ & $1000 \mu \mathrm{g} \mathrm{L}^{-1}$ & [96] \\
\hline & & & & & & 26 & & & & & & \\
\hline Diclofenac & & $\begin{array}{l}\text { Hospital } \\
\text { effluent }\end{array}$ & Spain & $\begin{array}{l}\text { SPE- } \\
\text { HPLC-MS/MS }\end{array}$ & 30 & $60-1900$ & [73] & & & $\begin{array}{l}\text { LOEC (7d) } \\
\text { (reproduction) }\end{array}$ & $2000 \mu \mathrm{g} \mathrm{L}^{-1}$ & [96] \\
\hline Diclofenac & & STP influent & Taiwan & $\begin{array}{l}\text { SPE-HPLC- } \\
\text { MS/MS }\end{array}$ & $-t$ & $3-347$ & [87] & Fish & D. rerio & $\begin{array}{l}\text { NOEC (10d) } \\
\text { (survival) }\end{array}$ & $4000 \mu \mathrm{g} \mathrm{L}^{-1}$ & [96] \\
\hline Diclofenac & & $\begin{array}{l}\text { STPeffluent } \\
\text { Pearl Rivers } \\
\text { water }\end{array}$ & China & GC-NCI-MS & 1.1 & $\begin{array}{l}\text { 4-101 } \\
\text { ND-147 ( } \pm 5)\end{array}$ & {$[88]$} & & & LOEC(10d)(survival) & $8000 \mu \mathrm{g} \mathrm{L}^{-1}$ & [96] \\
\hline \multirow[t]{4}{*}{ Diclofenac } & & STP influent & Luxembourg & SPE-LC-MS/MS & 0.3 & $2-43$ & [89] & Fish & O. mykiss & $\begin{array}{l}\text { LOEC (21 d) (liver } \\
\text { cytopathology) }\end{array}$ & $1 \mu \mathrm{gL}^{-1}$ & [97] \\
\hline & & STP effluent & & & & $0.3-78$ & & & & & & \\
\hline & & $\begin{array}{l}\text { Alzette river } \\
\text { water }\end{array}$ & & & & $0.3-55$ & & & & & & \\
\hline & & $\begin{array}{l}\text { Mess river } \\
\text { water }\end{array}$ & & & & $0.3-19$ & & & & & & \\
\hline Diclofenac & & STPeffluent & South Korea & SPE-LC-MS/MS & 1.0 & $8.8-127$ & [90] & & & $\begin{array}{l}\text { LOEC ( } 21 \text { d) (kidney } \\
\text { cytopathology) }\end{array}$ & $1 \mu \mathrm{gL}^{-1}$ & [97] \\
\hline Diclofenac & & $\begin{array}{l}\text { Surface water } \\
\text { STPeffluent }\end{array}$ & Spain & $\begin{array}{l}\text { SPE-LC-QqLIT- } \\
\text { MS }\end{array}$ & $4(\mathrm{LOQ})$ & $\begin{array}{l}1.1-6.8 \\
890-1440\end{array}$ & [91] & & & $\begin{array}{l}\text { LOEC }(21 \mathrm{~d})(\text { gills } \\
\text { cytopathology) }\end{array}$ & $1 \mu \mathrm{gL}^{-1}$ & [97] \\
\hline \multirow[t]{2}{*}{ Diclofenac } & & STP effluent & United Kingdom & $\begin{array}{l}\text { SPE- } \\
\text { HPLC-MS/MS }\end{array}$ & 20 & $350-460$ & [94] & & & & & \\
\hline & & Surface water & & & & $<20-91$ & & & & & & \\
\hline Fenoprofen & $53746-45-5$ & $\begin{array}{l}\text { STP influent } \\
\text { STP effluent }\end{array}$ & Japan & SPE-GC-MS & $1(\mathrm{LOQ})$ & $\begin{array}{l}9.68-80.6 \\
1.59-9.22\end{array}$ & {$[86]$} & & & & & \\
\hline Ibuprofen & $15687-27-1$ & STP influent & Spain & SPE-GC-MS & 23 & $34,000-168,000$ & [14] & Crustacean & D. magna & $\begin{array}{l}\mathrm{EC}_{50}(48 \mathrm{~h}) \\
\text { (immobilization) }\end{array}$ & $108 \mathrm{mgL}^{-1}$ & [65] \\
\hline Ibuprofen & & $\begin{array}{l}\text { STP effluent } \\
\text { STP influent }\end{array}$ & Switzerland & SPE-GC-MS & 8 & $\begin{array}{l}240-28,000 \\
1750-4500\end{array}$ & [15] & Algae & D. subspicatus & $\begin{array}{l}\mathrm{EC}_{50} \text { (growth } \\
\text { inhibition) }\end{array}$ & $315 \mathrm{mgL}^{-1}$ & [65] \\
\hline Ibuprofen & & $\begin{array}{l}\text { STPeffluent } \\
\text { STPeffluent }\end{array}$ & Canada & SPE-GC-MS & 0.8 & $\begin{array}{l}100-1200 \\
2235.2-6718.3\end{array}$ & [17] & Duckweed & L. minor & $\begin{array}{l}\mathrm{EC}_{50}(7 \mathrm{~d}) \text { (growth } \\
\text { inhibition) }\end{array}$ & $22 \mathrm{mgL}^{-1}$ & [65] \\
\hline Ibuprofen & & STP influent & Canada & SPE-GC-MS & 10 & $4100-10,210$ & [18] & Crustacean & Daphnia magna & $\begin{array}{l}\mathrm{EC}_{50}(48 \mathrm{~h}) \\
\text { (immobilisation) }\end{array}$ & $10-100 \mathrm{mg} \mathrm{L}^{-1}$ & [75] \\
\hline Ibuprofen & & $\begin{array}{l}\text { STPeffluent } \\
\text { Somes river } \\
\text { water }\end{array}$ & Romania & SPE-GC-MS & 30 (LOQ) & $\begin{array}{l}110-2170 \\
<30-115.2\end{array}$ & {$[20]$} & & & $\begin{array}{l}\mathrm{EC}_{50}(14 \mathrm{~d}) \\
\text { (reproduction) }\end{array}$ & $13.4 \mathrm{mg} \mathrm{L}^{-1}$ & [75] \\
\hline
\end{tabular}




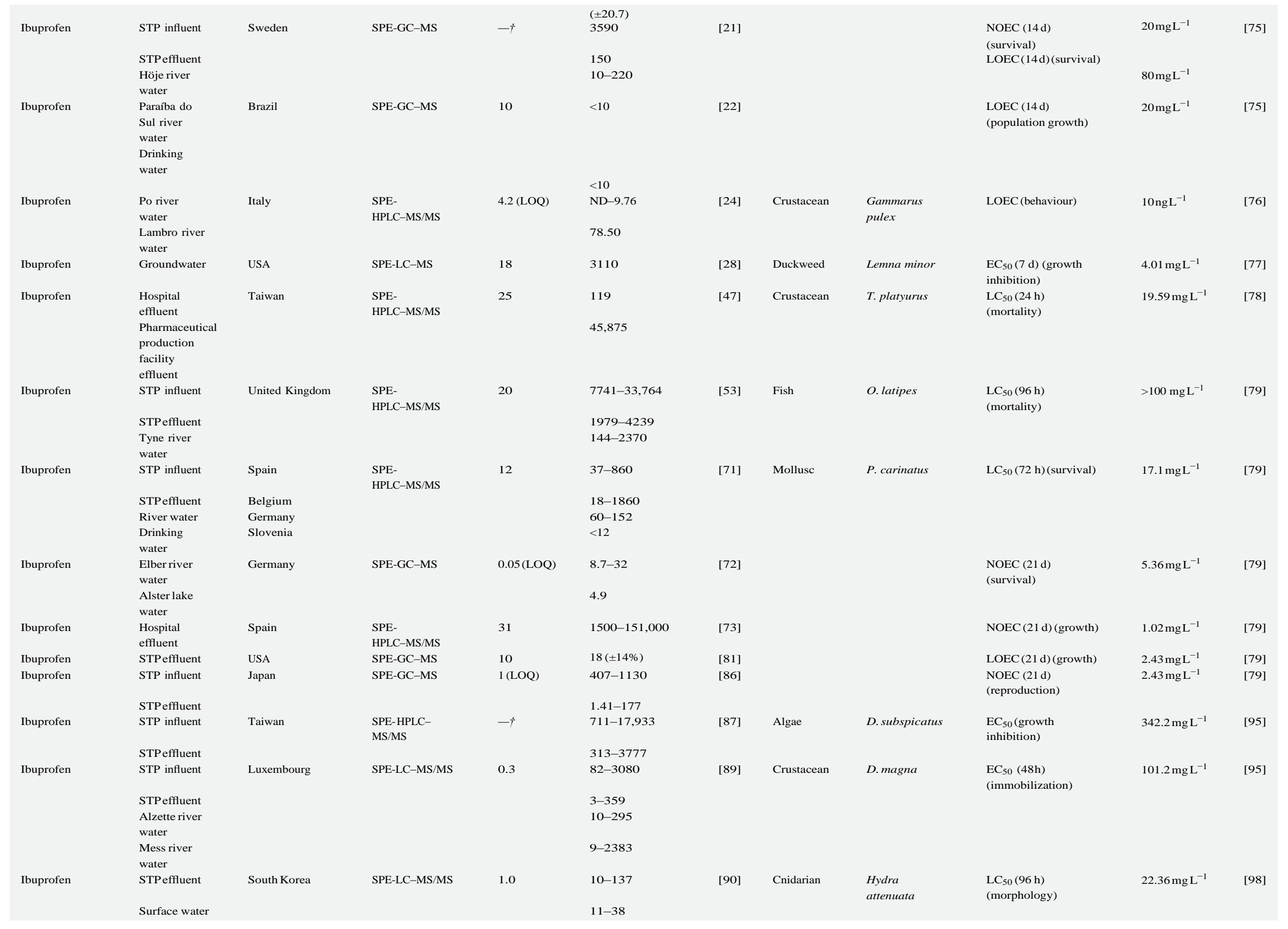




\begin{tabular}{|c|c|c|c|c|c|c|c|c|c|c|c|c|}
\hline Compound & CAS number & Sample & Country & $\begin{array}{l}\text { Analytical } \\
\text { procedure }\end{array}$ & $\operatorname{LOD}\left(\mathrm{ngL}^{-1}\right)$ & $\begin{array}{l}\text { Concentration } \\
\text { reported }\left(\mathrm{ngL}^{-1}\right)\end{array}$ & Ref. & Taxon & Species & $\begin{array}{l}\text { Toxicological } \\
\text { endpoint }\end{array}$ & $\begin{array}{l}\text { Ecotoxicity } \\
\text { data }\end{array}$ & Ref. \\
\hline & & $\begin{array}{l}\text { Drinking } \\
\text { water }\end{array}$ & & & & $<1.0$ & & & & & & \\
\hline Ibuprofen & & STPeffluent & Spain & $\begin{array}{l}\text { SPE-LC-QqLIT- } \\
\text { MS }\end{array}$ & 13 (LOQ) & $100-340$ & [91] & & & $\begin{array}{l}\mathrm{EC}_{50}(96 \mathrm{~h}) \\
\text { (morphology) }\end{array}$ & $1.65 \mathrm{mgL}^{-1}$ & [98] \\
\hline Ibuprofen & & $\begin{array}{l}\text { Mankyung } \\
\text { river water }\end{array}$ & South Korea & SPE-LC-MS/MS & 5 & $<5-414( \pm 13)$ & [92] & & & $\begin{array}{l}\text { LOEC }(96 \mathrm{~h}) \\
\text { (morphology) }\end{array}$ & $1 \mathrm{mgL}^{-1}$ & [98] \\
\hline \multirow[t]{3}{*}{ Ibuprofen } & & STP effluent & United Kingdom & $\begin{array}{l}\text { SPE- } \\
\text { HPLC-MS/MS }\end{array}$ & 20 & $1700-3800$ & [94] & & & $\begin{array}{l}\text { NOEC (96h) } \\
\text { (morphology) }\end{array}$ & $0.1 \mathrm{mgL}^{-1}$ & [98] \\
\hline & & Surface water & & & & $<20$ & & & & & & \\
\hline & & & & & & & & & & $\mathrm{EC}_{50}(96 \mathrm{~h}$ ) (feeding) & $3.85 \mathrm{mgL}^{-1}$ & [98] \\
\hline \multirow[t]{2}{*}{ Carboxy-ibuprofen* } & $-\dot{t}$ & STP influent & Sweden & SPE-GC-MS & -+ & 10,750 & {$[21]$} & & & & & \\
\hline & & $\begin{array}{l}\text { STP effluent } \\
\text { Höje river } \\
\text { water }\end{array}$ & & & & $\begin{array}{l}430 \\
230-680\end{array}$ & & & & & & \\
\hline \multirow[t]{2}{*}{ Carboxy-ibuprofen* } & & $\begin{array}{l}\text { Elber river } \\
\text { water }\end{array}$ & Germany & SPE-GC-MS & 0.21 & $11-32$ & [72] & & & & & \\
\hline & & $\begin{array}{l}\text { Alster lake } \\
\text { water }\end{array}$ & & & & 9.5 & & & & & & \\
\hline \multirow{2}{*}{ Hydroxy-ibuprofen* } & $-t$ & STP influent & Sweden & SPE-GC-MS & -+ & 990 & [21] & & & & & \\
\hline & & $\begin{array}{l}\text { STP effluent } \\
\text { Höje river } \\
\text { water }\end{array}$ & & & & $\begin{array}{l}50 \\
20-60\end{array}$ & & & & & & \\
\hline \multirow[t]{2}{*}{ Hydroxy-ibuprofen* } & & $\begin{array}{l}\text { Elber river } \\
\text { water }\end{array}$ & Germany & SPE-GC-MS & 0.38 & $32-101$ & {$[72]$} & & & & & \\
\hline & & $\begin{array}{l}\text { Alster lake } \\
\text { water }\end{array}$ & & & & 18 & & & & & & \\
\hline Indomethacin & 53-86-1 & $\begin{array}{l}\text { STP influent } \\
\text { STPeffluent }\end{array}$ & Canada & SPE-GC-MS & 10 & $30-430$ & {$[18]$} & & & & & \\
\hline Indomethacin & & STPeffluent & Spain & $\begin{array}{l}\text { SPE-LC-QqLIT- } \\
\text { MS }\end{array}$ & $8(\mathrm{LOQ})$ & $\begin{array}{l}40-490 \\
160-390\end{array}$ & [91] & Crustacean & T. platyurus & $\begin{array}{l}\mathrm{LC}_{50}(24 \mathrm{~h}) \\
\text { (mortality) }\end{array}$ & $16.14 \mathrm{mg} \mathrm{L}^{-1}$ & [78] \\
\hline Indomethacin & & $\begin{array}{l}\text { Mankyung } \\
\text { river water }\end{array}$ & South Korea & SPE-LC-MS/MS & 1 & $<1-33.5( \pm 8)$ & [92] & Fish & O. latipes & $\begin{array}{l}\mathrm{LC}_{50}(96 \mathrm{~h}) \\
\text { (mortality) }\end{array}$ & $81.92 \mathrm{mgL}^{-1}$ & [78] \\
\hline Ketoprofen & 22071-15-4 & STPeffluent & Canada & SPE-GC-MS/MS & 1.0 & $8-351$ & [17] & & & & & \\
\hline \multirow[t]{2}{*}{ Ketoprofen } & & STP influent & Canada & SPE-GC-MS & 10 & $60-150$ & [18] & & & & & \\
\hline & & STPeffluent & & & & $40-90$ & & & & & & \\
\hline \multirow{2}{*}{ Ketoprofen } & & $\begin{array}{l}\text { STP influent } \\
\text { STPeffluent }\end{array}$ & Sweden & SPE-GC-MS & -+ & 940 & [21] & & & & & \\
\hline & & $\begin{array}{l}\text { STPeffluent } \\
\text { Höje river } \\
\text { water }\end{array}$ & & & & $\begin{array}{l}330 \\
10-70\end{array}$ & & & & & & \\
\hline \multirow[t]{2}{*}{ Ketoprofen } & & $\begin{array}{l}\text { Hospital } \\
\text { effluent }\end{array}$ & Taiwan & $\begin{array}{l}\text { SPE- } \\
\text { HPLC-MS/MS }\end{array}$ & 10 & 9.6 & [47] & & & & & \\
\hline & & $\begin{array}{l}\text { Pharmaceutical } \\
\text { production } \\
\text { facility } \\
\text { effluent }\end{array}$ & & & & ND & & & & & & \\
\hline \multirow[t]{4}{*}{ Ketoprofen } & & STP influent & Spain & $\begin{array}{l}\text { SPE- } \\
\text { HPLC-MS/MS }\end{array}$ & 26 & 131 & {$[71]$} & & & & & \\
\hline & & STPeffluent & Belgium & & & $<26$ & & & & & & \\
\hline & & River water & Germany & & & $<26$ & & & & & & \\
\hline & & $\begin{array}{l}\text { Drinking } \\
\text { water }\end{array}$ & Slovenia & & & $<26$ & & & & & & \\
\hline Ketoprofen & & STPeffluent & USA & SPE-GC-MS & 9 & $23( \pm 6.8 \%)$ & {$[81]$} & & & & & \\
\hline Ketoprofen & & $\begin{array}{l}\text { STP influent } \\
\text { STP effluent }\end{array}$ & Japan & SPE-GC-MS & 0.3 (LOQ) & $\begin{array}{l}108-369 \\
68.1-219\end{array}$ & {$[86]$} & & & & & \\
\hline
\end{tabular}




\begin{tabular}{|c|c|c|c|c|c|c|c|c|c|c|c|c|}
\hline Ketorolac & 74103-06-3 & $\begin{array}{l}\text { Hospital } \\
\text { effluent }\end{array}$ & Spain & $\begin{array}{l}\text { SPE-HPLC- } \\
\text { MS/MS }\end{array}$ & 26 & $200-59,500$ & [73] & & & & & \\
\hline \multirow[t]{2}{*}{ Mefenamic acid } & $61-68-7$ & STP influent & United Kingdom & $\begin{array}{l}\text { SPE- } \\
\text { HPLC-MS/MS }\end{array}$ & 50 & $136-363$ & [53] & Crustacean & T. platyurus & $\begin{array}{l}\mathrm{LC}_{50}(24 \mathrm{~h}) \\
\text { (mortality) }\end{array}$ & $3.95 \mathrm{mg} \mathrm{L}^{-1}$ & [78] \\
\hline & & STPeffluent & & & & $290-396$ & & & & & & \\
\hline Mefenamic acid & & STP effluent & Japan & SPE-GC-MS & $1(\mathrm{LOQ})$ & $4.45-396$ & [86] & Fish & O. latipes & $\begin{array}{l}\mathrm{LC}_{50}(96 \mathrm{~h}) \\
\text { (mortality) }\end{array}$ & $8.04 \mathrm{mgL}^{-1}$ & [78] \\
\hline Mefenamic acid & & $\begin{array}{l}\text { Pearl Rivers } \\
\text { water }\end{array}$ & China & GC-NCI-MS & 2.2 & ND-22.4 $( \pm 3.1)$ & {$[88]$} & & & & & \\
\hline Mefenamic acid & & STP effluent & Spain & $\begin{array}{l}\text { SPE-LC-QqLIT- } \\
\text { MS }\end{array}$ & $3(\mathrm{LOQ})$ & $40-60$ & [91] & & & & & \\
\hline Mefenamic acid & & $\begin{array}{l}\text { Mankyung } \\
\text { river water }\end{array}$ & South Korea & SPE-LC-MS/MS & 10 & $<10-326( \pm 21)$ & [92] & & & & & \\
\hline \multirow[t]{2}{*}{ Mefenamic acid } & & STPeffluent & United Kingdom & $\begin{array}{l}\text { SPE- } \\
\text { HPLC-MS/MS }\end{array}$ & 50 & $720-1100$ & [94] & & & & & \\
\hline & & Surface water & & & & $<50-65$ & & & & & & \\
\hline Naproxen & $22204-53-1$ & STP effluent & Canada & SPE-GC-MS/MS & 0.5 & $271.4-7962.3$ & [17] & Crustacean & D. magna & $\begin{array}{l}\mathrm{EC}_{50}(48 \mathrm{~h}) \\
\text { (immobilization) }\end{array}$ & $174 \mathrm{mgL}^{-1}$ & [65] \\
\hline \multirow[t]{2}{*}{ Naproxen } & & STP influent & Canada & SPE-GC-MS & 10 & $1730-6030$ & [18] & Algae & D. subspicatus & $\begin{array}{l}\mathrm{EC}_{50} \text { (growth } \\
\text { inhibition) }\end{array}$ & $>320 \mathrm{mg} \mathrm{L}^{-1}$ & [65] \\
\hline & & STPeffluent & & & & $360-2540$ & & & & & & \\
\hline \multirow[t]{3}{*}{ Naproxen } & & STP influent & Sweden & SPE-GC-MS & $-t$ & 3650 & [21] & Duckweed & L. minor & $\begin{array}{l}\mathrm{EC}_{50}(7 \mathrm{~d}) \text { (growth } \\
\text { inhibition) }\end{array}$ & $24.2 \mathrm{mg} \mathrm{L}^{-1}$ & [65] \\
\hline & & STP effluent & & & & 250 & & & & & & \\
\hline & & $\begin{array}{l}\text { Höje river } \\
\text { water }\end{array}$ & & & & $90-250$ & & & & & & \\
\hline Naproxen & & $\begin{array}{l}\text { Paraíba do } \\
\text { Sul river } \\
\text { water } \\
\text { Drinking } \\
\text { water }\end{array}$ & Brazil & SPE-GC-MS & 10 & $<10-50$ & [22] & Rotifers & B. calyciflorus & $\mathrm{LC}_{50}(24 \mathrm{~h})$ & $62.48 \mathrm{mg} \mathrm{L}^{-1}$ & [80] \\
\hline Naproxen & & $\begin{array}{l}\text { Drinking } \\
\text { water }\end{array}$ & USA & SPE-LC-MS/MS & 0.5 & $\begin{array}{l}<10-30 \\
<0.5\end{array}$ & [32] & Rotifers & T. platyurus & $\mathrm{LC}_{50}(24 \mathrm{~h})$ & $84.09 \mathrm{mg} \mathrm{L}^{-1}$ & [80] \\
\hline \multirow[t]{2}{*}{ Naproxen } & & $\begin{array}{l}\text { Hospital } \\
\text { effluent }\end{array}$ & Taiwan & $\begin{array}{l}\text { SPE- } \\
\text { HPLC-MS/MS }\end{array}$ & 10 & 698 & [47] & Crustaceans & C. dubia & $\begin{array}{l}\mathrm{EC}_{50}(24 \mathrm{~h}) \\
\text { (immobilization) }\end{array}$ & $66.37 \mathrm{mg} \mathrm{L}^{-1}$ & [80] \\
\hline & & $\begin{array}{l}\text { Pharmaceutical } \\
\text { production } \\
\text { facility } \\
\text { effluent }\end{array}$ & & & & ND & & & & & & \\
\hline \multirow[t]{4}{*}{ Naproxen } & & STP influent & Spain & $\begin{array}{l}\text { SPE- } \\
\text { HPLC-MS/MS }\end{array}$ & 26 & $109-455$ & [71] & Algae & P. subcapitata & $\begin{array}{l}\mathrm{EC}_{50}(72 \mathrm{~h}) \text { (growth } \\
\text { inhibition) }\end{array}$ & $31.82 \mathrm{mg} \mathrm{L}^{-1}$ & [80] \\
\hline & & STPeffluent & Belgium & & & 625 & & & & & & \\
\hline & & River water & Germany & & & 70 & & & & & & \\
\hline & & $\begin{array}{l}\text { Drinking } \\
\text { water }\end{array}$ & Slovenia & & & $<26$ & & & & & & \\
\hline Naproxen & & STP effluent & USA & SPE-GC-MS & 9 & $31( \pm 5.5 \%)$ & [81] & Rotifers & B. calyciflorus & $\begin{array}{l}\mathrm{EC}_{50}(48 \mathrm{~h}) \text { (growth } \\
\text { inhibition) }\end{array}$ & $0.56 \mathrm{mgL}^{-1}$ & [80] \\
\hline Naproxen & & STP influent & Japan & SPE-GC-MS & $0.3(\mathrm{LOQ})$ & $38.0-230$ & [86] & Crustaceans & C. dubia & $\begin{array}{l}\mathrm{EC}_{50}(7 \mathrm{~d}) \text { (population } \\
\text { growth inhibition) }\end{array}$ & $0.33 \mathrm{mgL}^{-1}$ & [80] \\
\hline Naproxen & & $\begin{array}{l}\text { STPeffluent } \\
\text { Pearl Rivers } \\
\text { water }\end{array}$ & China & GC-NCI-MS & 1.3 & $\begin{array}{l}12.0-139 \\
\text { ND-118 }( \pm 10.1)\end{array}$ & {$[88]$} & Algae & D. subspicatus & $\begin{array}{l}\mathrm{EC}_{50} \text { (growth } \\
\text { inhibition) }\end{array}$ & $625.5 \mathrm{mgL}^{-1}$ & [95] \\
\hline \multirow[t]{3}{*}{ Naproxen } & & STP effluent & South Korea & SPE-LC-MS/MS & 1.0 & $20-483$ & [90] & Crustacean & D. magna & $\begin{array}{l}\mathrm{EC}_{50}(48 \mathrm{~h}) \\
\text { (immobilization) }\end{array}$ & $166.3 \mathrm{mg} \mathrm{L}^{-1}$ & [95] \\
\hline & & Surface water & & & & $1.8-18$ & & Cnidarian & $\begin{array}{l}\text { Hydra } \\
\text { attenuata }\end{array}$ & $\begin{array}{l}\mathrm{LC}_{50}(96 \mathrm{~h}) \\
\text { (morphology) }\end{array}$ & $22.36 \mathrm{mg} \mathrm{L}^{-1}$ & [98] \\
\hline & & & & & & & & & & $\begin{array}{l}\mathrm{EC}_{50}(96 \mathrm{~h}) \\
\text { (morphology) }\end{array}$ & $2.62 \mathrm{mg} \mathrm{L}^{-1}$ & [98] \\
\hline
\end{tabular}




\begin{tabular}{|c|c|c|c|c|c|c|c|c|c|c|c|c|}
\hline Compound & CAS number & Sample & Country & $\begin{array}{l}\text { Analytical } \\
\text { procedure }\end{array}$ & $\operatorname{LOD}\left(\mathrm{ngL}^{-1}\right)$ & $\begin{array}{l}\text { Concentration } \\
\text { reported }\left(\mathrm{ngL}^{-1}\right)\end{array}$ & Ref. & Taxon & Species & $\begin{array}{l}\text { Toxicological } \\
\text { endpoint }\end{array}$ & $\begin{array}{l}\text { Ecotoxicity } \\
\text { data }\end{array}$ & Ref. \\
\hline & & & & & & & & & & $\begin{array}{l}\text { LOEC }(96 \mathrm{~h}) \\
\text { (morphology) }\end{array}$ & $5 \mathrm{mgL}^{-1}$ & [98] \\
\hline & & & & & & & & & & $\begin{array}{l}\text { NOEC (96h) } \\
\text { (morphology) }\end{array}$ & $1 \mathrm{mgL}^{-1}$ & [98] \\
\hline & & & & & & & & & & $\mathrm{EC}_{50}(96 \mathrm{~h})$ (feeding) & $2.68 \mathrm{mgL}^{-1}$ & [98] \\
\hline Paracetamol & $103-90-2$ & $\begin{array}{l}\text { STP influent } \\
\text { STP effluent }\end{array}$ & Spain & SPE-GC-MS & 32 & $\begin{array}{l}29,000-246,000 \\
<32-4300\end{array}$ & [14] & Bacteria & V. fischeri & $\mathrm{EC}_{50}(15 \mathrm{~min})$ & $567.5 \mathrm{mgL}^{-1}$ & [82] \\
\hline Paracetamol & & Groundwater & USA & SPE-LC-MS & 9 & 380 & [28] & Crustacean & D. magna & $\begin{array}{l}\mathrm{EC}_{50}(48 \mathrm{~h}) \\
\text { (immobilization) }\end{array}$ & $30.1 \mathrm{mgL}^{-1}$ & [82] \\
\hline \multirow[t]{2}{*}{ Paracetamol } & & $\begin{array}{l}\text { Hospital } \\
\text { effluent }\end{array}$ & Taiwan & $\begin{array}{l}\text { SPE- } \\
\text { HPLC-MS/MS }\end{array}$ & 2 & 62,250 & [47] & & D. magna & $\begin{array}{l}\mathrm{EC}_{50}(96 \mathrm{~h}) \\
\text { (immobilization) }\end{array}$ & $26.6 \mathrm{mgL}^{-1}$ & [82] \\
\hline & & $\begin{array}{l}\text { Pharmaceutical } \\
\text { production } \\
\text { facility } \\
\text { effluent }\end{array}$ & & & & 124 & & & & & & \\
\hline \multirow[t]{2}{*}{ Paracetamol } & & STP influent & United Kingdom & $\begin{array}{l}\text { SPE- } \\
\text { HPLC-MS/MS }\end{array}$ & 20 & $5529-69,570$ & [53] & Fish & O. latipes & $\mathrm{LC}_{50}(48 \mathrm{~h})$ & $>160 \mathrm{mg} \mathrm{L}^{-1}$ & [82] \\
\hline & & STPeffluent & & & & $<20$ & & & & & & \\
\hline Paracetamol & & $\begin{array}{l}\text { Hospital } \\
\text { effluent }\end{array}$ & Spain & $\begin{array}{l}\text { SPE- } \\
\text { HPLC-MS/MS }\end{array}$ & 47 & $500-29,000$ & [73] & & O. latipes & $\mathrm{LC}_{50}(96 \mathrm{~h})$ & $>160 \mathrm{mg} \mathrm{L}^{-1}$ & [82] \\
\hline \multirow[t]{3}{*}{ Paracetamol } & & $\begin{array}{l}\text { Danube river } \\
\text { water }\end{array}$ & Serbia & SPE-LC-MS/MS & 0.50 & 78,170 & [84] & Bacteria & V. fischeri & $\mathrm{EC}_{50}(30 \mathrm{~min})$ & $650 \mathrm{mgL}^{-1}$ & [83] \\
\hline & & $\begin{array}{l}\text { Savariver } \\
\text { water }\end{array}$ & & & & 610 & & & & & & \\
\hline & & $\begin{array}{l}\text { Tamis river } \\
\text { water }\end{array}$ & & & & 310 & & & & & & \\
\hline \multirow[t]{2}{*}{ Paracetamol } & & STP effluent & South Korea & SPE-LC-MS/MS & 1.0 & $1.8-19$ & [90] & Algae & $\begin{array}{l}\text { Scenedesmus } \\
\text { subspicatus }\end{array}$ & $\mathrm{EC}_{50}(72 \mathrm{~h})$ & $134 \mathrm{mg} \mathrm{L}^{-1}$ & [83] \\
\hline & & Surface water & & & & $4.1-73$ & & & & & & \\
\hline \multirow[t]{2}{*}{ Paracetamol } & & $\begin{array}{l}\text { STP influent } \\
\text { STPeffluent }\end{array}$ & Korea & SPE-LC-MS & 5 & $\begin{array}{l}13,046-56,944 \\
<5-9\end{array}$ & [93] & Crustacean & D. magna & $\mathrm{EC}_{50}$ (immobilization) & $50 \mathrm{mgL}^{-1}$ & [83] \\
\hline & & $\begin{array}{l}\text { Han river } \\
\text { water }\end{array}$ & & & & $<5-127$ & & & & & & \\
\hline \multirow[t]{3}{*}{ Paracetamol } & & STP effluent & United Kingdom & $\begin{array}{l}\text { SPE- } \\
\text { HPLC-MS/MS }\end{array}$ & 50 & $<50$ & [94] & Ciliates & $\begin{array}{l}\text { Tetrahymena } \\
\text { pyriformis }\end{array}$ & $\begin{array}{l}\mathrm{EC}_{50}(48 \mathrm{~h}) \text { (growth } \\
\text { inhibition) }\end{array}$ & $112 \mathrm{mgL}^{-1}$ & [83] \\
\hline & & Surface water & & & & $<50$ & & & & & & \\
\hline & & & & & & & & Fish & $\begin{array}{l}\text { B. rerio (zebra } \\
\text { fish) }\end{array}$ & $\mathrm{LC}_{50}(48 \mathrm{~h})$ & $378 \mathrm{mgL}^{-1}$ & [83] \\
\hline
\end{tabular}

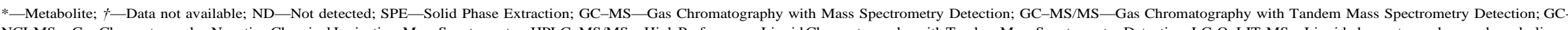

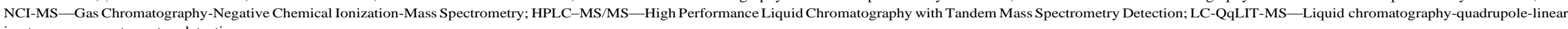
ion trap-mass spectrometry detection. 
$185.69 \mathrm{mg} \mathrm{L}^{-1}$ was found [70]. Diclofenac was detected in STP efflu- ents at maximum concentrations of 2.4 [15] and $1.42 \mu \mathrm{g} \mathrm{L}^{-1}$ [71] in Switzerland and Belgium respectively (Table 1) which highlighted that the effects cited are of sufficient magnitude to suspect chronic toxicity in aquatic organisms. Diclofenac has also been found in rivers [21,22,72], groundwater [26], hospital effluents [47,73] and drinking water $[22,32,71]$ but at concentrations in the order of $\mathrm{nL}^{-1}$.

Ibuprofen is another NSAID with documented chronic toxic- ity. Female Japanese medaka (the Japanese killifish, Oryzias latipes) exposed to different concentrations of the drug over six weeks, showed a sharp rise in liver weight together with enhanced egg production, yet with a reduction in the number of weekly spawning events [74]. Authors associated these phenomena with changes in the spawning process and vitellogenin production, a glycoprotein precursor in yolk formation. With the water flea Daphnia magna population growth rate was significantly reduced for concentra- tions ranging from 0 to $80 \mathrm{mg} \mathrm{L}^{-1}$ [75]. Reproduction was affected at all concentrations and completely inhibited at the highest phar- maceutical levels. An activity decrease of the freshwater amphipod Gammarus pulex was noticed when in contact with ibuprofen con- centrations of 1 and $10 \mathrm{ng} \mathrm{L}^{-1}$, the latter value corresponding to the LOEC $^{3}$ obtained for behaviour change [76]. Regarding aquatic pho- tosynthetic organisms, specific effects have been noticed. A 5-day exposure to concentrations in the $1-1000 \mu \mathrm{g} \mathrm{L}^{-1}$ range stimulated the growth of the cyanobacterium Synechocystis sp. while inhibiting that of the duckweed plant Lemna minor after 7 days [77]. Ibupro- fen has been detected in STP effluents at concentrations that can reach $28 \mu \mathrm{g} \mathrm{L}^{-1}$ [14] (Spain) (Table 1). Two metabolites of ibuprofen (carboxyl-ibuprofen and hydroxyl-ibuprofen) were also found in surface waters and in a Swedish STP (influent and effluent) [21,72]. Due to demonstrable chronic toxicity, this may represent a real threat to non-target organisms, even at those lower concentrations. Ibuprofen was also found in rivers [20-22,24,72] and drinking water [22] which may broaden the scope of the problem to public health. However, effects in humans caused by chronic exposure to this active substance still remain unknown.

The ecotoxicity of naproxen and its photoderivative products have also been envisaged. Acute toxicity tests performed on the rotifer Brachionus calyciflorus, the water flea Ceriodaphnia dubia and the fairy shrimp Thamnocephalus platyurus, showed that naproxen had $\mathrm{LC}_{50}{ }^{4}$ and $\mathrm{EC}_{50}{ }^{5}$ values within the $1-100 \mathrm{mg} \mathrm{L}^{-1}$ range, with the photolysis products being significantly more toxic [80]. Highly chronic toxic properties were equally noticed with algae being the less sensitive organisms. Yet again, degradation products were shown to be more toxic with $\mathrm{EC}_{50}$ values of 26 and $62 \mu \mathrm{g} \mathrm{L}^{-1}$ for

C. dubia, relative to growth inhibition. Naproxen had been found in STP effluents in a concentration range between $31 \mathrm{ng} \mathrm{L}^{-1}$ [81] and

$7.96 \mu \mathrm{g} \mathrm{L}^{-1}$ [17] and in surface waters [21,22,71], at concentration levels that can reach $250 \mathrm{ng} \mathrm{L}^{-1}$ [21]. This active substance was also detected in drinking water $[22,32,71]$.

The highly prescribed paracetamol (or acetaminophen) is a weak inhibitor of the cyclooxygenase enzyme, whose side effects are mainly associated with the formation of hepatotoxic metabo- lites, such as $N$ acetyl-p-benzoquinone imine (NAPQI) when the levels of liver glutathione are low [36]. Tests were carried out on algae, water fleas, fish embryos, luminescent bacteria and ciliates. The most sensitive species was shown to be $D$. magna for which $\mathrm{EC}_{50}$ values of 30.1 [82] or $50 \mathrm{mg} \mathrm{L}^{-1}$ [83] were reported. Some authors reported the presence of paracetamol in STP effluents at concen- trations below to $20 \mathrm{ng} \mathrm{L}^{-1}$ [53] to $4.3 \mu \mathrm{g} \mathrm{L}^{-1}$ [14], and in surface

\footnotetext{
${ }^{3}$ LOEC - Lowest Observed Effect Concentration.

${ }^{4} \mathrm{LC}_{50}$ - Half Maximal Lethal Concentration.

${ }^{5} \mathrm{EC}_{50}$ - Half Maximal Effective Concentration
}

waters, values can reach $78.17 \mu \mathrm{g} \mathrm{L}^{-1}$ [84] (Table 1), which are val- ues higher than the predicted no-effect concentration (PNEC) of $9.2 \mu \mathrm{g} \mathrm{L}^{-1}$ [85]. Hence, paracetamol might represent a threat for non-target organisms.

\subsection{Blood lipid lowering agents}

Modulating drugs for lipid metabolism are frequently prescribed in the developed world and aim to decrease the concentration of blood circulating cholesterol and triglycerides. Pharmaceuticals belonging to this therapeutic class can be divided into two main groups: statins and the group most frequently detected in the environment, fibrates [99]. Statins act by inhibiting the 3hydroxymethylglutaryl coenzyme A reductase (HMG-CoA), an enzyme involved in feedback control of cholesterol synthesis. In response, the number of LDL lipoprotein receptors at hepatocyte surfaces increases, thus lowering the circulating LDL cholesterol [100]. Toxicity data of statins on different organisms is very limited and restricted to the active substances simvastatin and atorvas- tatin. After an exposure of $96 \mathrm{~h}$ to simvastatin, larval and adult grass shrimp (Palaemonetes pugio) showed a $\mathrm{LC}_{50}$ of $1.18 \mathrm{mg} \mathrm{L}^{-1}$ and upper $10 \mathrm{mg} \mathrm{L}^{-1}$, respectively [101], while the harpacticoid copepod Nitocra spinipes had a 96-h $\mathrm{LC}_{50}$ of $0.81 \mathrm{mg} \mathrm{L}^{-1}$ [102]. Dahl et al. (2006) [102] also reported a significantly increase in development time and body length of the copepod for a range of concentrations between 0.16 and $1.6 \mu \mathrm{g} \mathrm{L}^{-1}$. On the other hand, simvastatin exhibited an $\mathrm{EC}_{50}$ of $22.8 \mathrm{mg} \mathrm{L}^{-1}$, after 96 $\mathrm{h}$, for the marine phytoplankton $D$. tertiolecta [70]. Relatively to atorvastatin, this active substance can affect the development of the duckweed Lemna gibba, showing a LOEC of $300 \mu \mathrm{g} \mathrm{L}^{-1}$ for parameters such as wet mass, frond number, chlorophyll- $a$ and carotenoids con- tent, for a time of exposure of 7 days [103]. Apart from statins had also the ability to suppress synthesis of the juvenile hormone in insects [104]. Statins were found in untreated sewage sam- ples (Table 2) at concentrations between 4 and $117 \mathrm{ng} \mathrm{L}^{-1}$ and in treated sewage samples at $1-59 \mathrm{ng} \mathrm{L}^{-1}[105,106]$. Additionally, they were also detected in surface water [105] and drinking water [32] at concentrations that can reach $1 \mathrm{ng} \mathrm{L}^{-1}$. In turn, fibrates act by activating specific transcription factors belonging to the nuclear hormone receptor super family, known as peroxisome proliferatoractivated receptors (PPARs) [107]. There are three types of PPARs related to different cellular events. PPAR- $a$ and PPAR- play key roles in catabolism and storage of fatty acids while PPAR-)' plays an important role in cellular differentiation [108]. Some authors have reported a proliferation of peroxisomes in rodent livers caused by fibrates [10]. Embryonic development of non-target organisms that share these receptors can be stopped by simply inhibiting cellular differentiation. Fibrates present in the micromolar con- centration range are sufficient to cause it in zebrafish (Danio rerio) [109,110] and amphibians [111]. Raldúa et al. [110] demonstrated that, when exposed to $0.5-1 \mathrm{mg} \mathrm{L}^{-1}$ of clofibrate, zebrafish larvae had a significantly shorter body length and their morphologic char- acteristics were also altered. Clofibrate-exposed zebrafish larvae had also lethargic behaviour. It was evidenced that gemfibrozil and bezafibrate significantly affect feeding, attachment and hydrant growth of the cnidarian Hydra attenuata [98]. According to Quinn et al. [98], gemfibrozil could be classified as toxic $\left(\mathrm{EC}_{50}\right.$ between 1 and $10 \mathrm{mg} \mathrm{L}^{-1}$ ) and bezafibrate as harmful for non-target organisms $\left(\mathrm{EC}_{50}\right.$ between 10 and $\left.100 \mathrm{mg} \mathrm{L}^{-1}\right)$. Toxic properties of gemfibrozil were also respectively investigated on the inhibition of the bac- terium Vibrio fischeri luminescence, growth inhibition of the alga Chlorella vulgaris and on the immobilization of the D. magna. In this study both the bacteria and the water flea were shown to be sensitive to gemfibrozil with the latter being the most sensitive, having an $\mathrm{EC}_{50}$ of $30 \mathrm{mg} \mathrm{L}^{-1}$ after $72 \mathrm{~h}[112]$. Proliferative inhibition 
Table 2

Examples of concentrations $\left(\mathrm{ng} \mathrm{L}^{-1}\right)$ of blood lipid lowering agents measured in different aquatic environments.

\begin{tabular}{|c|c|c|c|c|c|c|c|c|c|c|c|c|}
\hline Compound & CAS number & Sample & Country & $\begin{array}{l}\text { Analytical } \\
\text { procedure }\end{array}$ & $\operatorname{LOD}\left(\mathrm{ngL}^{-1}\right)$ & $\begin{array}{l}\text { Concentration } \\
\text { reported }\left(\mathrm{ngL}^{-1}\right)\end{array}$ & Ref. & Taxon & Species & $\begin{array}{l}\text { Toxicological } \\
\text { endpoint }\end{array}$ & $\begin{array}{l}\text { Ecotoxicity } \\
\text { data }\end{array}$ & Ref. \\
\hline \multicolumn{13}{|l|}{ Fibrates } \\
\hline \multirow[t]{2}{*}{ Bezafibrate } & 41859-67-0 & $\begin{array}{l}\text { Paraíba do } \\
\text { Sul river } \\
\text { water } \\
\text { Drinking } \\
\text { water }\end{array}$ & Brazil & SPE-GC-MS & 25 & $<25$ & [22] & Cnidarian & $\begin{array}{l}\text { Hydra } \\
\text { attenuata }\end{array}$ & $\begin{array}{l}\mathrm{LC}_{50}(96 \mathrm{~h}) \\
\text { (morphology) }\end{array}$ & $70.71 \mathrm{mg} \mathrm{L}^{-1}$ & [98] \\
\hline & & & & & & $<25$ & & & & & & \\
\hline \multirow[t]{2}{*}{ Bezafibrate } & & $\begin{array}{l}\text { Po river } \\
\text { water }\end{array}$ & Italy & $\begin{array}{l}\text { SPE- } \\
\text { HPLC-MS/MS }\end{array}$ & 0.3 & $0.79-2.75$ & [24] & & & $\begin{array}{l}\text { EC } 50(96 \mathrm{~h}) \\
\text { (morphology) }\end{array}$ & $25.85 \mathrm{mg} \mathrm{L}^{-1}$ & [98] \\
\hline & & $\begin{array}{l}\text { Lambro river } \\
\text { water }\end{array}$ & & & & 57.15 & & & & & & \\
\hline Bezafibrate & & STPeffluent & Spain & $\begin{array}{l}\text { SPE-LC-QqLIT- } \\
\text { MS }\end{array}$ & $3(\mathrm{LOQ})$ & $40-130$ & [91] & & & $\begin{array}{l}\text { LOEC (96h) } \\
\text { (morphology) }\end{array}$ & $1 \mathrm{mgL}^{-1}$ & [98] \\
\hline \multirow[t]{12}{*}{ Bezafibrate } & & STP effluent & Italy & $\begin{array}{l}\text { SPE- } \\
\text { HPLC-MS/MS }\end{array}$ & 0.1 (LOQ) & $0.3-117$ & [118] & & & $\begin{array}{l}\text { NOEC (96h) } \\
\text { (morphology) }\end{array}$ & $0.1 \mathrm{mgL}^{-1}$ & [98] \\
\hline & & & & & & & & & & $\mathrm{EC}_{50}(96 \mathrm{~h}$ ) (feeding) & $8.59 \mathrm{mgL}^{-1}$ & [98] \\
\hline & & & & & & & & Rotifer & B. calyciflorus & $\begin{array}{l}\mathrm{LC}_{50}(24 \mathrm{~h}) \\
\text { (mortality) }\end{array}$ & $60.91 \mathrm{mgL}^{-1}$ & [113] \\
\hline & & & & & & & & & & $\begin{array}{l}\mathrm{EC}_{50}(48 \mathrm{~h}) \\
\text { (population growth } \\
\text { inhibition) }\end{array}$ & $0.44 \mathrm{mgL}^{-1}$ & [113] \\
\hline & & & & & & & & & & NOEC (48h) & $0.156 \mathrm{mg} \mathrm{L}^{-1}$ & [113] \\
\hline & & & & & & & & & & LOEC (48h) & $0.3125 \mathrm{mgL}^{-1}$ & [113] \\
\hline & & & & & & & & Crustacean & T. platyurus & $\begin{array}{l}\mathrm{LC}_{50}(24 \mathrm{~h}) \\
\text { (mortality) }\end{array}$ & $39.69 \mathrm{mg} \mathrm{L}^{-1}$ & [113] \\
\hline & & & & & & & & & D. magna & $\begin{array}{l}\mathrm{EC}_{50}(24 \mathrm{~h}) \\
\text { (immobilization) }\end{array}$ & $100.08 \mathrm{mgL}^{-1}$ & [113] \\
\hline & & & & & & & & & C. dubia & $\begin{array}{l}\mathrm{EC}_{50}(48 \mathrm{~h}) \\
\text { (immobilization) }\end{array}$ & $75.79 \mathrm{mg} \mathrm{L}^{-1}$ & [113] \\
\hline & & & & & & & & & & $\begin{array}{l}\mathrm{EC}_{50}(7 \mathrm{~d}) \text { (population } \\
\text { growth inhibition) }\end{array}$ & $0.13 \mathrm{mg} \mathrm{L}^{-1}$ & [113] \\
\hline & & & & & & & & & & $\operatorname{NOEC}(7 \mathrm{~d})$ & $0.023 \mathrm{mg} \mathrm{L}^{-1}$ & [113] \\
\hline & & & & & & & & & & $\operatorname{LOEC}(7 \mathrm{~d})$ & $0.047 \mathrm{mg} \mathrm{L}^{-1}$ & [113] \\
\hline Clofibrate & $82115-62-6$ & & & & & & & Fish & D. rerio & $\begin{array}{l}\mathrm{LC}_{50}(96 \mathrm{~h}) \\
\text { (mortality) }\end{array}$ & $0.89 \mathrm{mg} \mathrm{L}^{-1}$ & [110] \\
\hline \multirow[t]{11}{*}{ Fenofibrate } & $49562-28-9$ & & & & & & & Rotifer & B. calyciforus & $\begin{array}{l}\mathrm{LC}_{50}(24 \mathrm{~h}) \\
\text { (mortality) }\end{array}$ & $64.97 \mathrm{mg} \mathrm{L}^{-1}$ & [113] \\
\hline & & & & & & & & & & $\begin{array}{l}\mathrm{EC}_{50}(48 \mathrm{~h}) \\
\text { (population growth } \\
\text { inhibition) }\end{array}$ & $1.44 \mathrm{mgL}^{-1}$ & [113] \\
\hline & & & & & & & & & & $\operatorname{NOEC}(48 \mathrm{~h})$ & $0.156 \mathrm{mg} \mathrm{L}^{-1}$ & [113] \\
\hline & & & & & & & & & & LOEC $(48 \mathrm{~h})$ & $0.3125 \mathrm{mgL}^{-1}$ & [113] \\
\hline & & & & & & & & Crustacean & D. magna & $\begin{array}{l}\mathrm{EC}_{50}(24 \mathrm{~h}) \\
\text { (immobilization) }\end{array}$ & $50.12 \mathrm{mg} \mathrm{L}^{-1}$ & [113] \\
\hline & & & & & & & & & C. dubia & $\begin{array}{l}\mathrm{EC}_{50}(7 \mathrm{~d}) \text { (population } \\
\text { growth inhibition) }\end{array}$ & $0.76 \mathrm{mg} \mathrm{L}^{-1}$ & [113] \\
\hline & & & & & & & & & & $\operatorname{NOEC}(7 \mathrm{~d})$ & $0.039 \mathrm{mg} \mathrm{L}^{-1}$ & [113] \\
\hline & & & & & & & & & & $\operatorname{LOEC}(7 \mathrm{~d})$ & $0.078 \mathrm{mg} \mathrm{L}^{-1}$ & [113] \\
\hline & & & & & & & & Algae & P. subcapitata & $\begin{array}{l}\mathrm{EC}_{50}(72 \mathrm{~h}) \text { (growth } \\
\text { inhibition) }\end{array}$ & $19.84 \mathrm{mg} \mathrm{L}^{-1}$ & [113] \\
\hline & & & & & & & & & & $\operatorname{NOEC}(72 \mathrm{~h})$ & $3.12 \mathrm{mgL}^{-1}$ & [113] \\
\hline & & & & & & & & & & LOEC (72h) & $6.25 \mathrm{mgL}^{-1}$ & [113] \\
\hline Clofibric acid* & 882-09-7 & STP influent & Greece & SPE-GC-MS & 1.8 & ND & [19] & Crustacean & D. magna & $\begin{array}{l}\mathrm{EC}_{50}(48 \mathrm{~h}) \\
\text { (immobilization) }\end{array}$ & $72 \mathrm{mgL}^{-1}$ & [65] \\
\hline
\end{tabular}




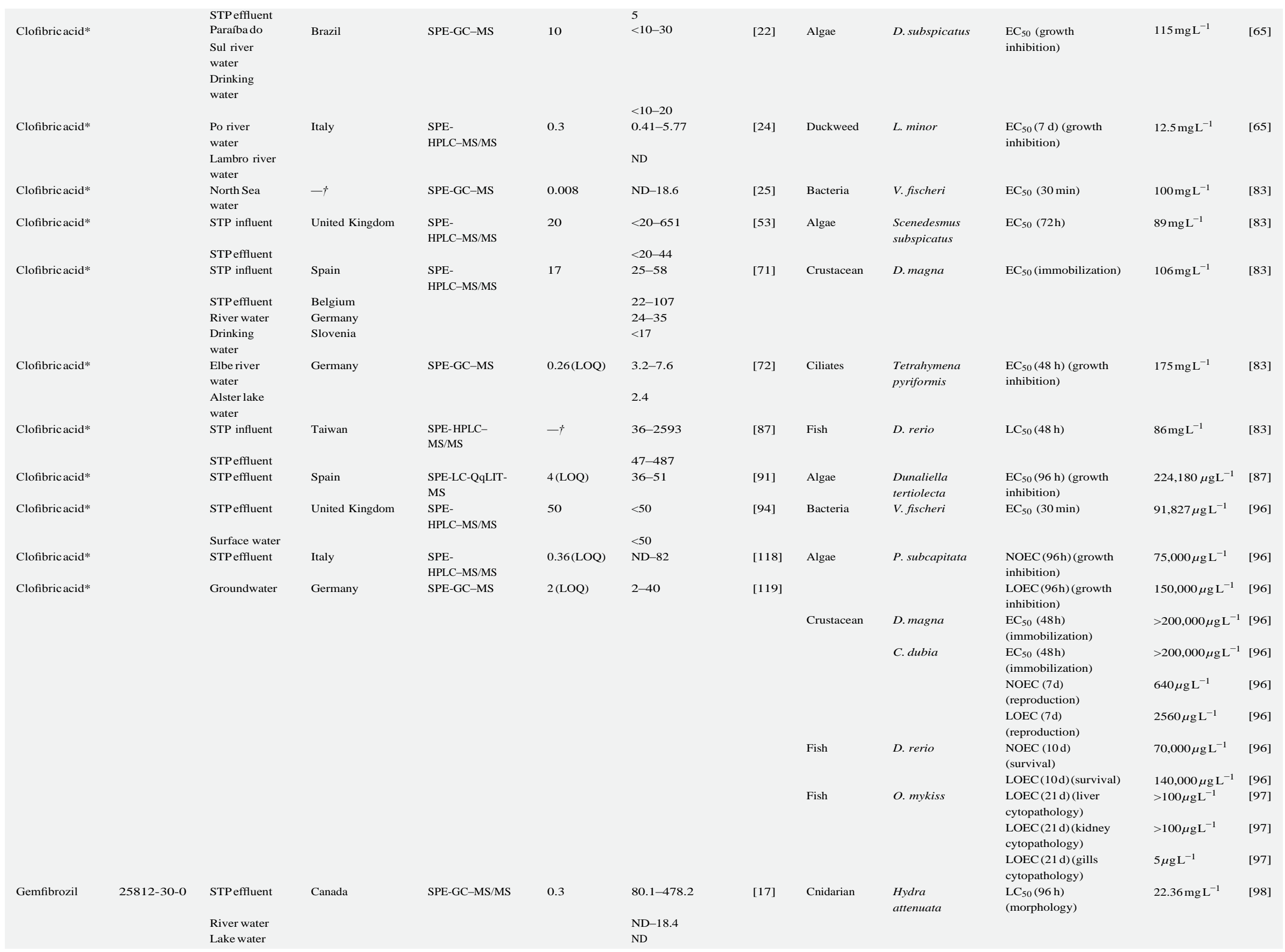




\begin{tabular}{|c|c|c|c|c|c|c|c|c|c|c|c|c|}
\hline Compound & CAS number & Sample & Country & $\begin{array}{l}\text { Analytical } \\
\text { procedure }\end{array}$ & $\operatorname{LOD}\left(\mathrm{ngL}^{-1}\right)$ & $\begin{array}{l}\text { Concentration } \\
\text { reported }\left(\mathrm{ngL}^{-1}\right)\end{array}$ & Ref. & Taxon & Species & $\begin{array}{l}\text { Toxicological } \\
\text { endpoint }\end{array}$ & $\begin{array}{l}\text { Ecotoxicity } \\
\text { data }\end{array}$ & Ref. \\
\hline \multirow[t]{2}{*}{ Gemfibrozil } & & STP influent & Canada & SPE-GC-MS & 10 & $120-36,530$ & [18] & & & $\begin{array}{l}\mathrm{EC}_{50}(96 \mathrm{~h}) \\
\text { (morphology) }\end{array}$ & $1.18 \mathrm{mg} \mathrm{L}^{-1}$ & [98] \\
\hline & & STPeffluent & & & & $80-2090$ & & & & & & \\
\hline \multirow[t]{3}{*}{ Gemfibrozil } & & STP influent & Sweden & SPE-GC-MS & $-t$ & 710 & [21] & & & $\begin{array}{l}\text { LOEC (96h) } \\
\text { (morphology) }\end{array}$ & $1 \mathrm{mgL}^{-1}$ & [98] \\
\hline & & STPeffluent & & & & 180 & & & & & & \\
\hline & & $\begin{array}{l}\text { Höje river } \\
\text { water }\end{array}$ & & & & $1-170$ & & & & & & \\
\hline Gemfibrozil & & $\begin{array}{l}\text { Drinking } \\
\text { water }\end{array}$ & USA & SPE-LC-MS/MS & 0.25 & 0.43 & [32] & & & $\begin{array}{l}\text { NOEC (96h) } \\
\text { (morphology) }\end{array}$ & $0.1 \mathrm{mgL}^{-1}$ & [98] \\
\hline \multirow[t]{2}{*}{ Gemfibrozil } & & $\begin{array}{l}\text { Hospital } \\
\text { effluent }\end{array}$ & Taiwan & $\begin{array}{l}\text { SPE- } \\
\text { HPLC-MS/MS }\end{array}$ & 1.0 & 760 & [47] & & & $\mathrm{EC}_{50}(96 \mathrm{~h})$ (feeding) & $1.76 \mathrm{mgL}^{-1}$ & [98] \\
\hline & & $\begin{array}{l}\text { Pharmaceutical } \\
\text { production } \\
\text { facility } \\
\text { effluent }\end{array}$ & & & & 1795 & & & & & & \\
\hline Gemfibrozil & & $\begin{array}{l}\text { Pearl rivers } \\
\text { water }\end{array}$ & China & SPE-GC-NCI-MS & 1.8 & $\mathrm{ND}-22.4( \pm 3.1)$ & [88] & Bacteria & V. fischeri & $\begin{array}{l}\mathrm{EC}_{50}(24 \mathrm{~h}) \\
\text { (bioluminescence) }\end{array}$ & $64.6 \mathrm{mg} \mathrm{L}^{-1}$ & [112] \\
\hline \multirow[t]{2}{*}{ Gemfibrozil } & & STPeffluent & South Korea & SPE-LC-MS/MS & 1.0 & $3.9-17$ & [90] & & & $\begin{array}{l}\mathrm{EC}_{50}(48 \mathrm{~h}) \\
\text { (bioluminescence) }\end{array}$ & $45.1 \mathrm{mg} \mathrm{L}^{-1}$ & [112] \\
\hline & & Surface water & & & & $1.8-9.1$ & & & & & & \\
\hline \multirow[t]{19}{*}{ Gemfibrozil } & & STPeffluent & Spain & $\begin{array}{l}\text { SPE-LC-QqLIT- } \\
\text { MS }\end{array}$ & $4(\mathrm{LOQ})$ & $470-3550$ & [91] & Algae & $\begin{array}{l}\text { Chlorella } \\
\text { vulgaris }\end{array}$ & $\mathrm{EC}_{50}(24 \mathrm{~h})($ growth) & $195 \mathrm{mgL}^{-1}$ & [112] \\
\hline & & & & & & & & & & $\mathrm{EC}_{50}(48 \mathrm{~h})$ (growth) & $161 \mathrm{mgL}^{-1}$ & [112] \\
\hline & & & & & & & & & & $\mathrm{EC}_{50}(72 \mathrm{~h})$ (growth) & $150 \mathrm{mgL}^{-1}$ & [112] \\
\hline & & & & & & & & Crustacean & D. magna & $\begin{array}{l}\mathrm{EC}_{50}(24 \mathrm{~h}) \\
\text { (immobilization) }\end{array}$ & $57.1 \mathrm{mgL}^{-1}$ & [112] \\
\hline & & & & & & & & & & $\begin{array}{l}\mathrm{EC}_{50}(48 \mathrm{~h}) \\
\text { (immobilization) }\end{array}$ & $42.6 \mathrm{mg} \mathrm{L}^{-1}$ & [112] \\
\hline & & & & & & & & & & $\begin{array}{l}\mathrm{EC}_{50}(72 \mathrm{~h}) \\
\text { (immobilization) }\end{array}$ & $30.0 \mathrm{mgL}^{-1}$ & [112] \\
\hline & & & & & & & & Bacteria & V. fischeri & $\begin{array}{l}\mathrm{EC}_{50}(30 \mathrm{~min}) \\
\text { (bioluminescence) }\end{array}$ & $85.74 \mathrm{mg} \mathrm{L}^{-1}$ & [113] \\
\hline & & & & & & & & Rotifer & B. calyciflorus & $\begin{array}{l}\mathrm{LC}_{50}(24 \mathrm{~h}) \\
\text { (mortality) }\end{array}$ & $77.30 \mathrm{mg} \mathrm{L}^{-1}$ & [113] \\
\hline & & & & & & & & & & $\begin{array}{l}\mathrm{EC}_{50}(48 \mathrm{~h}) \\
\text { (population growth } \\
\text { inhibition) }\end{array}$ & $0.44 \mathrm{mg} \mathrm{L}^{-1}$ & [113] \\
\hline & & & & & & & & & & $\operatorname{NOEC}(48 \mathrm{~h})$ & $0.156 \mathrm{mg} \mathrm{L}^{-1}$ & [113] \\
\hline & & & & & & & & & & $\operatorname{LOEC}(48 \mathrm{~h})$ & $0.312 \mathrm{mg} \mathrm{L}^{-1}$ & [113] \\
\hline & & & & & & & & Crustacean & T. platyurus & $\begin{array}{l}\mathrm{LC}_{50}(24 \mathrm{~h}) \\
\text { (mortality) }\end{array}$ & $161.05 \mathrm{mgL}^{-1}$ & [113] \\
\hline & & & & & & & & & D. magna & $\begin{array}{l}\mathrm{EC}_{50}(24 \mathrm{~h}) \\
\text { (immobilization) }\end{array}$ & $74.30 \mathrm{mg} \mathrm{L}^{-1}$ & [113] \\
\hline & & & & & & & & & C. dubia & $\begin{array}{l}\mathrm{EC}_{50}(7 \mathrm{~d}) \text { (population } \\
\text { growth inhibition) }\end{array}$ & $0.53 \mathrm{mgL}^{-1}$ & [113] \\
\hline & & & & & & & & & & $\operatorname{NOEC}(7 d)$ & $0.078 \mathrm{mg} \mathrm{L}^{-1}$ & [113] \\
\hline & & & & & & & & & & $\operatorname{LOEC}(7 d)$ & $0.156 \mathrm{mg} \mathrm{L}^{-1}$ & [113] \\
\hline & & & & & & & & Algae & P. subcapitata & $\begin{array}{l}\mathrm{EC}_{50}(72 \mathrm{~h}) \text { (growth } \\
\text { inhibition) }\end{array}$ & $15.19 \mathrm{mg} \mathrm{L}^{-1}$ & [113] \\
\hline & & & & & & & & & & $\operatorname{NOEC}(72 \mathrm{~h})$ & $3.125 \mathrm{mg} \mathrm{L}^{-1}$ & [113] \\
\hline & & & & & & & & & & $\operatorname{LOEC}(72 \mathrm{~h})$ & $6.25 \mathrm{mgL}^{-1}$ & [113] \\
\hline \multicolumn{13}{|l|}{ Statins } \\
\hline Atorvastatin & $134523-03-8$ & $\begin{array}{l}\text { Drinking } \\
\text { water }\end{array}$ & USA & SPE-LC-MS/MS & 0.25 & $<0.25$ & [32] & Duckweed & L. gibba & $\begin{array}{l}\text { LOEC }(7 \mathrm{~d}) \text { (growth } \\
\text { parameters) }\end{array}$ & $300 \mu \mathrm{gL}^{-1}$ & [103] \\
\hline
\end{tabular}




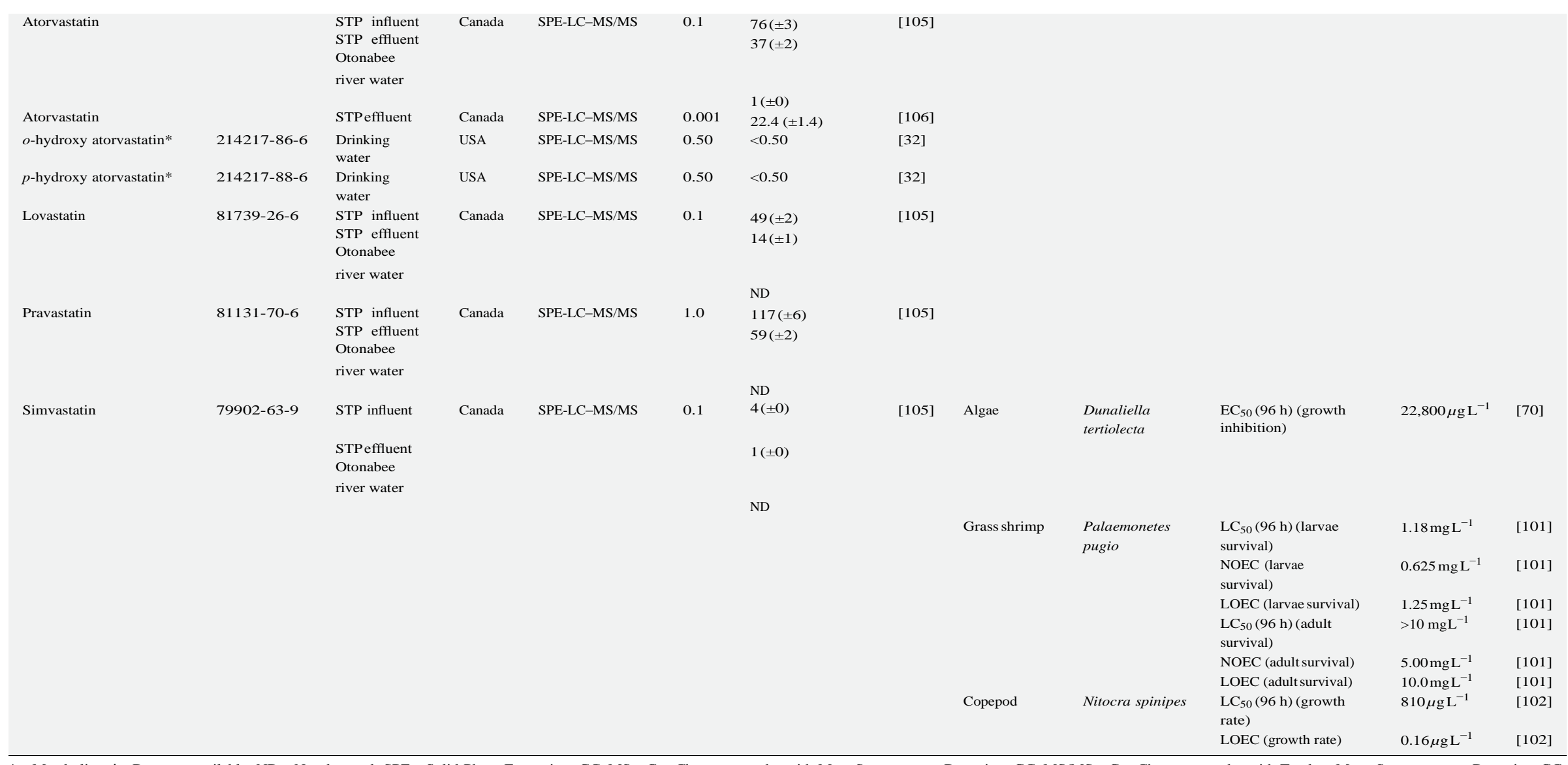

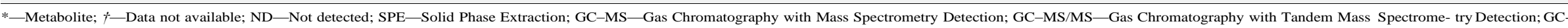

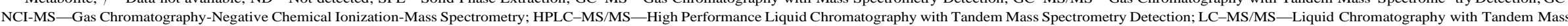
Spectrometry Detection. 
of C. vulgaris was only observed for concentrations up to $150 \mathrm{mg} \mathrm{L}^{-1}$ [112]. Isidori et al. [113] studied the acute and chronic toxicities caused by bezafibrate, fenofibrate and gemfibrozil and their photoproducts on non-target organisms, considering that they did not significantlyaffect the exposed organisms ( $\mathrm{LC}_{50}$ valuesranged from 39.69 to $161.05 \mathrm{mg} \mathrm{L}^{-1}$ ). When goldfish (Carassius auratus) were exposed to $1.5 \mu \mathrm{g} \mathrm{L}^{-1}$ of gemfibrozil for 14 days, a decrease of more than $50 \%$ in plasma testosterone levels was noticed [114], thereby proving that this pharmaceutical may also act as an endocrine dis- ruptor. As the main active metabolite of several fibrate compounds, clofibric acid is frequently used to assess toxicity due to its high degree of persistence in the environment. In acute toxicity tests on bacteria, ciliates, daphnids and fish embryos, Ferrari et al. [96] noticed low toxicity when at concentrations up to $14 \mathrm{mg} \mathrm{L}^{-1}$. These results are in agreement with the tests performed on three estuar-

ine species: algae D. tertiolecta, crustacean $P$. pugio and fish Fundulus heteroclitus [115]. For concentrations $\leq 1000 \mu \mathrm{g} \mathrm{L}^{-1}$, clofibric acid did not significantly affect cell density and growth rate of the first, neither did it affect the survival of the remainder. This is in agree-

ment with the $96-\mathrm{LC}_{50}$ of $224.18 \mathrm{mg} \mathrm{L}^{-1}$ found for D. tertiolecta [87]. On the contrary, exposure to concentrations above $10 \mu \mathrm{g} \mathrm{L}^{-1}$ and up to $100 \mu \mathrm{g} \mathrm{L}^{-1}$ increased the proportion of male offspring

produced by D. magna [116]. Rotifers have also shown to be sensitive and a $\mathrm{NOEC}^{6}$ value of $250 \mu \mathrm{g} \mathrm{L}^{-1}$ was deduced [96]. Fathead minnow fish (Pimephales promelas) showed alterations in reproductive function expressed by a reduction in sperm motility and plasma androgen concentration [117] while cytological changes in gills were noticed in rainbow trout exposed to $5 \mu \mathrm{g} \mathrm{L}^{-1}$ of this metabolite [97]. Fibrates (as bezafibrate and gemfibrozil) have been detected in several environmental samples (Table 2). Bezafibrate was found in STP effluents [91,118] and in the Paraíba do Sul river (Brazil) [22] as was gemfibrozil [17,18,21] and further iden- tified in surface waters $[17,21,88]$. Due to its greater persistence, clofibric acid has been found in STP influents [19,71] and effluents [19,53,71], surface water $[22,24,71]$, drinking water [71,119] and North Sea water [25]. All of these pharmaceuticals were shown to be present at concentration levels in the order of $\mathrm{ng} \mathrm{L}^{-1}$ or low

$\mu \mathrm{g} \mathrm{L}^{-1}$, which indicates that their exposure may represent a threat for non-targetorganisms.

\subsection{Antibiotics}

Antibiotics come within a therapeutic class where human health preservation and environmental disturbance are closely related. The major concern is associated with the development of resistance mechanisms by bacteria which can subsequently compromise public health by means of treatment effectiveness [52,108]. According
to Jones et al. [120], antibiotics could be classified as extremely

toxic to microorganisms $\left(\mathrm{EC}_{50}\right.$ below $\left.0.1 \mathrm{mg} \mathrm{L}^{-1}\right)$ and very toxic to algae ( $\mathrm{EC}_{50}$ between 0.1 and $1 \mathrm{mg} \mathrm{\textrm {L } ^ { - 1 }}$ ). Chronic toxicity tests performed on algae have shown high sensitivity to antibacte- rial agents as deduced from growth inhibition measurements [121,122]. Vertebrates (such as fish) put directly in contact with low levels of antimicrobials apparently did not yield observable effects [123,124]. Accordingly, a LC50 value above $100 \mathrm{mg} \mathrm{L}^{-1}$ for Japanese medaka concerning sulfonamides was reported [81]. However, one must bear in mind that algae constitute the basis of the food chain and a decrease in their population will directly affect the entire aquatic ecosystem equilibrium [123,125]. Exposure of D. magna to erythromycin, lincomycin, sulfamethoxazole or trimethoprim

in a concentration ranging from 1 to $100 \mu \mathrm{g} \mathrm{L}^{-1}$ did not affect the degree of survival, normorphology in adults or neonates, nor fecun-

\footnotetext{
${ }^{6}$ NOEC - Non-Observed Effect Concentration.
}

dity or sex ratio [116]. Similar results were obtained after chronic exposure to $10 \mu \mathrm{g} \mathrm{L}^{-1}$ of sulfamethoxazole [116]. Amoxicillin concentrations ranging from $50 \mathrm{ng} \mathrm{L}^{-1}$ to $50 \mathrm{mg} \mathrm{L}^{-1}$ were tested on four different algae without observable effects, unless for the blue-green algae Synechococcus leopolensis for which a NOEC of $0.78 \mu \mathrm{g} \mathrm{L}^{-1}$ was achieved [126]. Isidori et al. [124] tested erythromycin, oxytetracyclin, sulfamethoxazole, ofloxacin, lincomycin and clarithromycin on aquatic organisms belonging to different trophic levels (bacte- ria, algae, rotifers, crustaceans and fish). Results showed that acute toxicity level was in the order of $\mathrm{mg} \mathrm{L}^{-1}$ while chronic toxicity appeared at concentrations in the order of $\mu \mathrm{g} \mathrm{L}^{-1}$, mainly for algae. The antibiotics tested were shown to be less active against rotifers, crustaceans and fish where no effect was noticed even for con- centrations up to $1000 \mathrm{mg}$ $\mathrm{L}^{-1}$. After a $48 \mathrm{~h}$ exposure period of the microalga Scenedesmus obliquus to a concentration range of nor- floxacin between 0 and $60 \mathrm{mg}$ $\mathrm{L}^{-1}$ was noticed a growth inhibition $\left(\mathrm{EC}_{50}=38.49 \mathrm{mg} \mathrm{L}^{-1}\right)$ and a reduction in chlorophyll- $a$ concentra- tion [127].

Most antibiotics used in veterinary medicine are aimed at preventing and treating diseases in livestock production or aquaculture. Even considering their use at sub-therapeutically con- centrations, many studies suggest the development of bacterial resistance and further potential appearance of cross-resistance between different classes of antibiotics shared with humans $[43,58,120,128]$. Antibiotics used in livestock production are excreted in the urine and faeces of animals and often appear in manure. From here they can cause some problems in terres- trial ecosystems such as adverse effects on nitrifying bacteria [11] or growth inhibition of crop plants and weeds by bioaccu- mulation [129]. The presence of antibiotics in STP influents may also impair treatment processes that use bacteria and cause toxic effects in the downstream aquatic and/or terrestrial ecosystems at different trophic levels [11]. Bacterial cultures from sewage bioreactors receiving waters from a STP were tested for resis- tance against six antibiotics, showing that all were resistant to at least two of the antibiotics, whilst bacteria isolated from receiv- ing waters were only resistant to erythromycin and ampicillin [130]. Aquatic photosynthetic organisms can also be affected. A study performed both on the cyanobacterium Synechocystis sp. and the duckweed L. minor showed growth inhibition in the presence of 1$1000 \mu \mathrm{g} \mathrm{L}^{-1}$ erythromycin while another antibiotic, tetracycline, inhibited growth of the former when at concentra- tions between 10 and $100 \mu \mathrm{g} \mathrm{L}^{-1}$ while stimulating the latter [77]. Eguchi et al. [131] studied the influence of several antimi- crobial agents used as veterinary drugs in Japan on the growth of the green algae Selenastrum capricornutum and C. vulgaris by considering the growth inhibitory activity. Erithromycin showed

the strongest activity against $S$. capricornutum with an $\mathrm{EC}_{50}$ value of $37 \mu \mathrm{gL}^{-1}$ followed by dihydrostreptomycin $\left(\mathrm{EC}_{50}=110 \mu \mathrm{gL}^{-1}\right)$, oxytetracycline $\left(\mathrm{EC}_{50}=340 \mu \mathrm{g} \mathrm{L}^{-1}\right)$ and tylosin $\left(\mathrm{EC}_{50}=410 \mu \mathrm{g} \mathrm{L}^{-1}\right)$. Sulfonamides exhibited lower inhibitory activity with $\mathrm{EC}_{50}$ val- ues between 1.53 and $2.30 \mathrm{mg} \mathrm{L}^{-1}$. In contrast, ampicillin and cefalozin did not show any effect even at concentrations as high as $1000 \mathrm{mg} \mathrm{L}^{-1}$. The authors also showed the arousal of a synergis- tic inhibitory growth activity from the very common combination of sulfamethoxazole with trimethoprim in medicines, when com- pared to the respective individual activities. Yamashita et al. [132] evaluated the growth inhibition of the algae $P$. subcapitata by two antibiotics, levofloxacin and clarithromycin, showing that the last one had a more pronounced toxic effect with an $\mathrm{EC}_{50}$ of

$11 \mu \mathrm{gL}^{-}{ }^{1}$ and a LOEC and a NOEC of 6.3 and $3.1 \mu \mathrm{gL}{ }^{1}$, respec-

tively. Toxic effects of sulfachlorpyridazine and oxytetracycline were also tested on the aquatic plant $L$. minor, showing $\mathrm{EC}_{50}$ values of 2.33 and $4.92 \mathrm{mg} \mathrm{L}^{-1}$, respectively [133]. Assays on $D$. magna showed that following $48 \mathrm{~h}$ of exposure, oxolinic acid and tiamulin were the most toxic compounds, with $\mathrm{EC}_{50}$ values of 
Table 3

Examples of concentrations $\left(\mathrm{ng} \mathrm{L}^{-1}\right)$ of antibiotics measured in different aquatic environments.

\begin{tabular}{|c|c|c|c|c|c|c|c|c|c|c|c|c|}
\hline Compound & CAS number & Sample & Country & $\begin{array}{l}\text { Analytical } \\
\text { procedure }\end{array}$ & $\operatorname{LOD}\left(\mathrm{ngL}^{-1}\right)$ & $\begin{array}{l}\text { Concentration } \\
\text { reported }\left(\mathrm{ngL}^{-1}\right)\end{array}$ & Ref. & Taxon & Species & $\begin{array}{l}\text { Toxicological } \\
\text { endpoint }\end{array}$ & $\begin{array}{l}\text { Ecotoxicity } \\
\text { data }\end{array}$ & Ref. \\
\hline \multicolumn{13}{|c|}{ (Fluor)quinolones } \\
\hline Ciprofloxacin & 85721-33-1 & Surface water & USA & SPE-LC-MS & 20 & 20 & [23] & & & & & \\
\hline \multirow[t]{2}{*}{ Ciprofloxacin } & & $\begin{array}{l}\text { Po river } \\
\text { water }\end{array}$ & Italy & $\begin{array}{l}\text { SPE- } \\
\text { HPLC-MS/MS }\end{array}$ & 0.3 & ND-26.15 & [24] & & & & & \\
\hline & & $\begin{array}{l}\text { Lambro river } \\
\text { water }\end{array}$ & & & & 14.36 & & & & & & \\
\hline \multirow[t]{5}{*}{ Ciprofloxacin } & & STP influent & USA & $\begin{array}{l}\text { SPE- } \\
\text { HPLC-MS/MS }\end{array}$ & 20 & ND-1000 & {$[138]$} & & & & & \\
\hline & & STPeffluent & & & & $\mathrm{ND}$ & & & & & & \\
\hline & & Hospital & & & & ND-2000 & & & & & & \\
\hline & & effluent & & & & & & & & & & \\
\hline & & $\begin{array}{l}\text { Rio Grande } \\
\text { river water }\end{array}$ & & & & ND & & & & & & \\
\hline \multirow[t]{3}{*}{ Ciprofloxacin } & & STP influent & Portugal & SPE-LC-FD & 25 (LOQ) & $418.8-667.1$ & [139] & & & & & \\
\hline & & STPeffluent & & & & $100.8-309.2$ & & & & & & \\
\hline & & $\begin{array}{l}\text { Hospital } \\
\text { effluent }\end{array}$ & & & & $127.0-10,962.5$ & & & & & & \\
\hline \multirow[t]{2}{*}{ Ciprofloxacin } & & STP influent & USA & SPE-LC-MS & 50 & 150 & {$[140]$} & & & & & \\
\hline & & STPeffluent & & & & 60 & & & & & & \\
\hline Ciprofloxacin & & $\begin{array}{l}\text { STP influent } \\
\text { STP effluent }\end{array}$ & Sweden & SPE-LC-MS & $6(\mathrm{LOQ})$ & $\begin{array}{l}90-300 \\
<6-60\end{array}$ & [141] & & & & & \\
\hline Ciprofloxacin & & $\begin{array}{l}\text { Mondego } \\
\text { river water }\end{array}$ & Portugal & SPE-LC-FD & 25 & $79.6-119.2$ & {$[142]$} & & & & & \\
\hline \multirow[t]{3}{*}{ Enrofloxacin } & $93106-60-6$ & STP influent & Portugal & SPE-LC-FD & 50 (LOQ) & $121.8-447.1$ & [139] & Bacteria & V. fischeri & $\begin{array}{l}\mathrm{EC}_{50}(15 \mathrm{~min}) \\
\text { (luminescence) }\end{array}$ & $326.8 \mathrm{mgL}^{-1}$ & {$[13] 6$} \\
\hline & & STPeffluent & & & & $53.7-211.5$ & & & & & & \\
\hline & & $\begin{array}{l}\text { Hospital } \\
\text { effluent }\end{array}$ & & & & $<50$ & & & & & & \\
\hline \multirow[t]{2}{*}{ Enrofloxacin } & & STP influent & USA & SPE-LC-MS & 50 & 250 & {$[140]$} & Crustacean & D. magna & $\begin{array}{l}\mathrm{EC}_{50}(24 \mathrm{~h}) \\
\text { (immobilization) }\end{array}$ & $131.7 \mathrm{mgL}^{-1}$ & [136] \\
\hline & & STP effluent & & & & 270 & & & & & & \\
\hline \multirow[t]{5}{*}{ Enrofloxacin } & & $\begin{array}{l}\text { Mondego } \\
\text { river water }\end{array}$ & Portugal & SPE-LC-FD & 25 & $67.0-102.5$ & [142] & & & $\begin{array}{l}\mathrm{EC}_{50}(48 \mathrm{~h}) \\
\text { (immobilization) }\end{array}$ & $56.7 \mathrm{mgL}^{-1}$ & [136] \\
\hline & & & & & & & & & & $\begin{array}{l}\mathrm{EC}_{50}(21 \mathrm{~d}) \text { (adult } \\
\text { survival) }\end{array}$ & $11.47 \mathrm{mg} \mathrm{L}^{-1}$ & [136] \\
\hline & & & & & & & & & & $\begin{array}{l}\text { LOEC (21 d) } \\
\text { (reproduction) }\end{array}$ & $15 \mathrm{mgL}^{-1}$ & [136] \\
\hline & & & & & & & & & & $\begin{array}{l}\text { NOEC (21 d) } \\
\text { (reproduction) }\end{array}$ & $5 \mathrm{mgL}^{-1}$ & [136] \\
\hline & & & & & & & & & M. macrocopa & $\begin{array}{l}\mathrm{EC}_{50}(24 \mathrm{~h}) \\
\text { (immobilization) }\end{array}$ & $285.7 \mathrm{mg} \mathrm{L}^{-1}$ & [136] \\
\hline \multirow[t]{7}{*}{ Levofloxacin } & $100986-34-5$ & $\begin{array}{l}\text { Mankyung } \\
\text { river water }\end{array}$ & South Korea & SPE-LC-MS/MS & 5 & ND-87.4 $( \pm 13)$ & [92] & Crustacean & T. platyurus & $\begin{array}{l}\mathrm{LC}_{50}(24 \mathrm{~h}) \\
\text { (mortality) }\end{array}$ & $>100 \mathrm{mg} \mathrm{L}^{-1}$ & {$[78]$} \\
\hline & & & & & & & & Fish & O. latipes & $\begin{array}{l}\mathrm{LC}_{50}(96 \mathrm{~h}) \\
\text { (mortality) }\end{array}$ & $>100 \mathrm{mg} \mathrm{L}^{-1}$ & [78] \\
\hline & & & & & & & & Algae & P. subcapitata & $\begin{array}{l}\mathrm{EC}_{50}(96 \mathrm{~h}) \text { (growth } \\
\text { inhibition) }\end{array}$ & $1200 \mu \mathrm{g} \mathrm{L}^{-1}$ & [132] \\
\hline & & & & & & & & & & $\begin{array}{l}\text { LOEC (96h) (growth } \\
\text { inhibition) }\end{array}$ & $630 \mu \mathrm{gL}^{-1}$ & [132] \\
\hline & & & & & & & & & & $\begin{array}{l}\text { NOEC (96h) (growth } \\
\text { inhibition) }\end{array}$ & $310 \mu \mathrm{gL}^{-1}$ & [132] \\
\hline & & & & & & & & Crustacean & D. magna & $\begin{array}{l}\mathrm{EC}_{50}(21 \mathrm{~d}) \\
\text { (reproduction) }\end{array}$ & $340 \mu \mathrm{gL}^{-1}$ & [132] \\
\hline & & & & & & & & & & $\begin{array}{l}\text { LOEC (21 d) } \\
\text { (reproduction) }\end{array}$ & $63 \mu \mathrm{gL}^{-1}$ & [132] \\
\hline
\end{tabular}




\begin{tabular}{|c|c|c|c|c|c|c|c|c|c|c|c|c|}
\hline Compound & CAS number & Sample & Country & $\begin{array}{l}\text { Analytical } \\
\text { procedure }\end{array}$ & $\operatorname{LOD}\left(\mathrm{ngL}^{-1}\right)$ & $\begin{array}{l}\text { Concentration } \\
\text { reported }\left(\mathrm{ngL}^{-1}\right)\end{array}$ & Ref. & Taxon & Species & $\begin{array}{l}\text { Toxicological } \\
\text { endpoint }\end{array}$ & $\begin{array}{l}\text { Ecotoxicity } \\
\text { data }\end{array}$ & Ref. \\
\hline & & & & & & & & & & $\begin{array}{l}\operatorname{NOEC}(21 \mathrm{~d}) \\
\text { (reproduction) }\end{array}$ & $31 \mu \mathrm{gL}^{-1}$ & [132] \\
\hline \multirow[t]{2}{*}{ Nalidixic acid } & $389-08-2$ & STP influent & Taiwan & $\begin{array}{l}\text { SPE-HPLC- } \\
\text { MS/MS }\end{array}$ & $-\dagger$ & $26-372$ & [87] & & & & & \\
\hline & & STPeffluent & & & & $40-200$ & & & & & & \\
\hline Norfloxacin & 70458-96-7 & Surface water & USA & SPE-LC-MS & 20 & 120 & [23] & Algae & S. obliquus & $\begin{array}{l}\mathrm{IC}_{50}(48 \mathrm{~h}) \text { (growth } \\
\text { inhibition) }\end{array}$ & $38.49 \mathrm{mg} \mathrm{L}^{-1}$ & [127] \\
\hline \multirow[t]{3}{*}{ Norfloxacin } & & STP influent & Portugal & SPE-LC-FD & 25 (LOQ) & $191.2-455.0$ & [139] & Algae & S. capricornutum & $\begin{array}{l}\mathrm{EC}_{50} \text { (growth } \\
\text { inhibition) }\end{array}$ & $16.6 \mathrm{mg} \mathrm{L}^{-1}$ & [131] \\
\hline & & STPeffluent & & & & $29.6-35.0$ & & & & & & \\
\hline & & $\begin{array}{l}\text { Hospital } \\
\text { effluent }\end{array}$ & & & & $<25-334.0$ & & & & & & \\
\hline \multirow[t]{2}{*}{ Norfloxacin } & & STP influent & Sweden & SPE-LC-MS & $7(\mathrm{LOQ})$ & $72-174$ & [141] & & & $\begin{array}{l}\text { NOEC (growth } \\
\text { inhibition) }\end{array}$ & $4.01 \mathrm{mg} \mathrm{L}^{-1}$ & [131] \\
\hline & & STP effluent & & & & $<6-37$ & & & & & & \\
\hline Norfloxacin & & $\begin{array}{l}\text { Mondego } \\
\text { river water }\end{array}$ & Portugal & SPE-LC-FD & 25 & $\mathrm{ND}$ & [142] & & C. vulgaris & $\begin{array}{l}\mathrm{EC}_{50} \text { (growth } \\
\text { inhibition) }\end{array}$ & $10.4 \mathrm{mg} \mathrm{L}^{-1}$ & [131] \\
\hline \multirow[t]{2}{*}{ Norfloxacin } & & $\begin{array}{l}\text { Surface } \\
\text { seawater }\end{array}$ & China & $\begin{array}{l}\text { SPE- } \\
\text { HPLC-MS/MS }\end{array}$ & 13 & $<13-8.00$ & [144] & & & $\begin{array}{l}\text { NOEC (growth } \\
\text { inhibition) }\end{array}$ & $4.02 \mathrm{mg} \mathrm{L}^{-1}$ & [131] \\
\hline & & & (Hong Kong) & & & & & & & & & \\
\hline \multirow[t]{3}{*}{ Norfloxacin } & & $\begin{array}{l}\text { Victoria } \\
\text { Harbour } \\
\text { seawater }\end{array}$ & China & SPE-HPLC-MS & 3.2 (LOQ seawater) & $9.4-12.3$ & [145] & Rotifer & B. calyciflorus & $\begin{array}{l}\mathrm{LC}_{50}(24 \mathrm{~h}) \\
\text { (mortality) }\end{array}$ & $29.88 \mathrm{mg} \mathrm{L}^{-1}$ & [124] \\
\hline & & $\begin{array}{l}\text { Pearl River } \\
\text { water }\end{array}$ & & & 10 (LOQ riverwater) & & & & & & & \\
\hline & & & & & & $12-150$ & & & & & & \\
\hline \multirow[t]{2}{*}{ Ofloxacin } & 82419-36-1 & STP influent & Taiwan & $\begin{array}{l}\text { SPE-HPLC- } \\
\text { MS/MS }\end{array}$ & $-t$ & $115-1274$ & [87] & & & $\begin{array}{l}\mathrm{EC}_{50}(48 \mathrm{~h}) \\
\text { (population growth } \\
\text { inhibition) }\end{array}$ & $0.53 \mathrm{mg} \mathrm{L}^{-1}$ & [124] \\
\hline & & STPeffluent & & & & 53-991 & & & & & & \\
\hline \multirow[t]{4}{*}{ Ofloxacin } & & STP influent & USA & $\begin{array}{l}\text { SPE- } \\
\text { HPLC-MS/MS }\end{array}$ & 10 & ND-1000 & [138] & Crustacean & T. platyurus & $\begin{array}{l}\mathrm{LC}_{50}(24 \mathrm{~h}) \\
\text { (mortality) }\end{array}$ & $33.98 \mathrm{mg} \mathrm{L}^{-1}$ & [124] \\
\hline & & STPeffluent & & & & 110 & & & & & & \\
\hline & & $\begin{array}{l}\text { Hospital } \\
\text { effluent }\end{array}$ & & & & ND- 35,500 & & & & & & \\
\hline & & $\begin{array}{l}\text { Rio Grande } \\
\text { river water }\end{array}$ & & & & $\mathrm{ND}$ & & & & & & \\
\hline \multirow[t]{3}{*}{ Ofloxacin } & & STP influent & Portugal & SPE-LC-FD & 250 & ND & [139] & & D. magna & $\begin{array}{l}\mathrm{EC}_{50}(24 \mathrm{~h}) \\
\text { (immobilization) }\end{array}$ & $31.75 \mathrm{mg} \mathrm{L}^{-1}$ & [124] \\
\hline & & STPeffluent & & & & ND & & & & & & \\
\hline & & $\begin{array}{l}\text { Hospital } \\
\text { effluent }\end{array}$ & & & & ND-10,675.5 & & & & & & \\
\hline \multirow[t]{2}{*}{ Ofloxacin } & & STP influent & Sweden & SPE-LC-MS & $6(\mathrm{LOQ})$ & $<6-287$ & [141] & & C. dubia & $\begin{array}{l}\mathrm{EC}_{50}(24 \mathrm{~h}) \\
\text { (immobilization) }\end{array}$ & $17.41 \mathrm{mg} \mathrm{L}^{-1}$ & [124] \\
\hline & & STPeffluent & & & & $<6-52$ & & & & & & \\
\hline \multirow[t]{4}{*}{ Ofloxacin } & & $\begin{array}{l}\text { Victoria } \\
\text { Harbour } \\
\text { seawater }\end{array}$ & China & SPE-HPLC-MS & 2.6 (LOQseawater) & $5.2-10$ & [145] & & & $\begin{array}{l}\mathrm{EC}_{50}(7 \mathrm{~d}) \text { (population } \\
\text { growth inhibition) }\end{array}$ & $3.13 \mathrm{mg} \mathrm{L}^{-1}$ & [124] \\
\hline & & $\begin{array}{l}\text { Pearl River } \\
\text { water }\end{array}$ & & & 10 (LOQ riverwater) & & & & & & & \\
\hline & & & & & & $11-77$ & & & & & & \\
\hline & & & & & & & & Algae & P. subcapitata & $\begin{array}{l}\mathrm{EC}_{50}(72 \mathrm{~h}) \text { (growth } \\
\text { inhibition) }\end{array}$ & $1.44 \mathrm{mg} \mathrm{L}^{-1}$ & [124] \\
\hline Oxolinic acid & $14698-29-4$ & & & & & & & Algae & M. aeruginosa & $\begin{array}{l}\mathrm{EC}_{50}(72 \mathrm{~h}) \text { (growth } \\
\text { inhibition) }\end{array}$ & $0.180 \mathrm{mgL}^{-1}$ & [122] \\
\hline
\end{tabular}




\begin{tabular}{|c|c|c|c|c|c|c|c|c|c|c|c|c|}
\hline & & & & & & & & & R. salina & $\mathrm{EC}_{50}(72 \mathrm{~h})$ (growth & $10 \mathrm{mgL}^{-1}$ & [122] \\
\hline & & & & & & & & & $\begin{array}{l}S . \\
\text { capricornutum }\end{array}$ & $\begin{array}{l}\mathrm{EC}_{50}(72 \mathrm{~h}) \text { (growth } \\
\text { inhibition) }\end{array}$ & $16 \mathrm{mgL}^{-1}$ & [122] \\
\hline & & & & & & & & Crustacean & D. magna & $\begin{array}{l}\text { EC } 50(24 \mathrm{~h}) \\
\text { (immobilization) }\end{array}$ & $5.9 \mathrm{mgL}^{-1}$ & [134] \\
\hline & & & & & & & & & & $\begin{array}{l}\mathrm{EC}_{50}(48 \mathrm{~h}) \\
\text { (immobilization) }\end{array}$ & $4.6 \mathrm{mgL}^{-1}$ & [134] \\
\hline & & & & & & & & & & $\begin{array}{l}\text { NOEC(21 d) } \\
\text { (reproduction) }\end{array}$ & $0.38 \mathrm{mgL}^{-1}$ & [134] \\
\hline \multirow[t]{2}{*}{ Sarafloxacin } & 98105-99-8 & & & & & & & Algae & R. salina & $\begin{array}{l}\mathrm{EC}_{50}(72 \mathrm{~h}) \text { (growth } \\
\text { inhibition) }\end{array}$ & $24 \mathrm{mgL}^{-1}$ & [122] \\
\hline & & & & & & & & & $\begin{array}{l}\text { S. } \\
\text { capricornutum }\end{array}$ & $\begin{array}{l}\mathrm{EC}_{50}(72 \mathrm{~h}) \text { (growth } \\
\text { inhibition) }\end{array}$ & $16 \mathrm{mgL}^{-1}$ & [122] \\
\hline \multirow[t]{6}{*}{$\begin{array}{l}\text {-Lactams } \\
\text { Amoxicillin }\end{array}$} & $81030-75-3$ & & & & & & & Algae & M. aeruginosa & $\begin{array}{l}\mathrm{EC}_{50}(72 \mathrm{~h})(\text { growth } \\
\text { inhibition) }\end{array}$ & $0.0037 \mathrm{mg} \mathrm{L}^{-1}$ & [122] \\
\hline & & & & & & & & & $\begin{array}{l}\text { S. } \\
\text { capricornutum }\end{array}$ & $\begin{array}{l}\operatorname{NOEC}(72 \mathrm{~h}) \text { (growth } \\
\text { inhibition) }\end{array}$ & $250 \mathrm{mgL}^{-1}$ & [122] \\
\hline & & & & & & & & Algae & S. leopoliensis & $\begin{array}{l}\mathrm{EC}_{50} \text { (growth } \\
\text { inhibition) }\end{array}$ & $2.22 \mu \mathrm{gL}^{-1}$ & [126] \\
\hline & & & & & & & & & & $\begin{array}{l}\text { NOEC (growth } \\
\text { inhibition) LOEC }\end{array}$ & $0.78 \mu \mathrm{gL}^{-1}$ & [126] \\
\hline & & & & & & & & & & $\begin{array}{l}\text { (growth } \\
\text { inhibition) }\end{array}$ & $1.56 \mu \mathrm{gL}^{-1}$ & [126] \\
\hline & & & & & & & & Bacteria & V. fischeri & $\begin{array}{l}\mathrm{EC}_{50}(15 \mathrm{~min}) \\
\text { (luminescence) }\end{array}$ & $3597 \mathrm{mg} \mathrm{L}^{-1}$ & [136] \\
\hline \multirow[t]{2}{*}{ Ampicillin } & 69-53-4 & $\begin{array}{l}\text { Hospital effluent } \\
\text { Pharmaceutical }\end{array}$ & t Taiwan & $\begin{array}{l}\text { SPE-HPLC- } \\
\text { MS/MS }\end{array}$ & 10 & 21 & [47] & Bacteria & V.fischeri & $\begin{array}{l}\mathrm{EC}_{50}(15 \mathrm{~min}) \\
\text { (luminescence) }\end{array}$ & $2627 \mathrm{mg} \mathrm{L}^{-1}$ & [136] \\
\hline & & $\begin{array}{l}\text { production } \\
\text { facility } \\
\text { effluent }\end{array}$ & & & & ND & & & & & & \\
\hline \multirow[t]{2}{*}{ Penicillin G (Benzylpenicillin) } & $69-57-8$ & $\begin{array}{l}\text { STPinfluent } \\
\text { STPeffluent }\end{array}$ & China & SPE-LC-MS & 930 (LOQ) & $\begin{array}{l}153,000 \pm 4000 \\
1680 \pm 480\end{array}$ & [48] & Algae & M. aeruginosa & $\mathrm{EC}_{50}$ (growth rate) & $0.006 \mathrm{mg} \mathrm{L}^{-1}$ & [121] \\
\hline & & & & & & & & & $\begin{array}{l}\text { S. } \\
\text { capricornutum }\end{array}$ & NOEC (growth rate) & $100 \mathrm{mgL}^{-1}$ & [121] \\
\hline Cephalosporins & & & & & & & & & & & & \\
\hline Cephalexin & $66905-57-5$ & STP influent & Taiwan & $\begin{array}{l}\text { SPE- HPLC- } \\
\text { MS/MS }\end{array}$ & -+ & $1563-4367$ & [87] & & & & & \\
\hline \multirow[t]{2}{*}{ Cephalexin } & & $\begin{array}{l}\text { STP effluent } \\
\text { Surface } \\
\text { seawater }\end{array}$ & China & $\begin{array}{l}\text { SPE- } \\
\text { HPLC-MS/MS }\end{array}$ & 13 & $\begin{array}{c}10-994 \\
<13-182\end{array}$ & [144] & & & & & \\
\hline & & & (Hong Kong) & & \multicolumn{3}{|c|}{ Lincosamide } & & & & & \\
\hline Lincomycin & $154-21-2$ & Surface water & USA & SPE-LC-MS & 50 & 60 & [23] & Rotifer & B. calyciflorus & $\begin{array}{r}\mathrm{LC}_{50}(24 \mathrm{~h}) \\
\text { (mortality) }\end{array}$ & $24.94 \mathrm{mg} \mathrm{L}^{-1}$ & [124] \\
\hline \multirow[t]{2}{*}{ Lincomycin } & & $\begin{array}{l}\text { Po river } \\
\text { water }\end{array}$ & Italy & $\begin{array}{l}\text { SPE- } \\
\text { HPLC-MS/MS }\end{array}$ & 0.3 & $3.13-248.90$ & [24] & & & $\begin{array}{l}\mathrm{EC}_{50}(48 \mathrm{~h}) \\
\text { (population growth } \\
\text { inhibition) }\end{array}$ & $0.68 \mathrm{mgL}^{-1}$ & [124] \\
\hline & & $\begin{array}{l}\text { Lambroriver } \\
\text { water }\end{array}$ & & & & 24.40 & & & & & & \\
\hline Lincomycin & & Groundwater & USA & SPE-LC-MS & 50 & 320 & [28] & Crustacean & T. platyurus & $\begin{array}{r}\mathrm{LC}_{50}(24 \mathrm{~h}) \\
\text { (mortality) }\end{array}$ & $30.00 \mathrm{mg} \mathrm{L}^{-1}$ & [124] \\
\hline \multirow[t]{2}{*}{ Lincomycin } & & $\begin{array}{l}\text { Hospital } \\
\text { effluent } \\
\text { Livestock } \\
\text { effluent }\end{array}$ & USA & $\begin{array}{l}\text { SPE- } \\
\text { HPLC-MS/MS }\end{array}$ & 10 & $\begin{array}{l}\text { ND-2000 } \\
\text { ND-6600 }\end{array}$ & [138] & & D. magna & $\begin{array}{l}\mathrm{EC}_{50}(24 \mathrm{~h}) \\
\quad \text { (immobilization) }\end{array}$ & $23.18 \mathrm{mg} \mathrm{L}^{-1}$ & [124] \\
\hline & & & & & & & & & C. dubia & $\begin{array}{l}\mathrm{EC}_{50}(24 \mathrm{~h}) \\
\text { (immobilization) }\end{array}$ & $13.98 \mathrm{mg} \mathrm{L}^{-1}$ & [124] \\
\hline
\end{tabular}




\begin{tabular}{|c|c|c|c|c|c|c|c|c|c|c|c|c|}
\hline Compound & CAS number & Sample & Country & $\begin{array}{l}\text { Analytical } \\
\text { procedure }\end{array}$ & $\operatorname{LOD}\left(\mathrm{ngL}^{-1}\right)$ & $\begin{array}{l}\text { Concentration } \\
\text { reported }\left(\mathrm{ngL}^{-1}\right)\end{array}$ & Ref. & Taxon & Species & $\begin{array}{l}\text { Toxicological } \\
\text { endpoint }\end{array}$ & $\begin{array}{l}\text { Ecotoxicity } \\
\text { data }\end{array}$ & Ref. \\
\hline & & & & & & & & & & $\begin{array}{l}\mathrm{EC}_{50}(7 \mathrm{~d}) \text { (population } \\
\text { growth inhibition) }\end{array}$ & $7.20 \mathrm{mg} \mathrm{L}^{-1}$ & [124] \\
\hline & & & & & & & & Algae & P. subcapitata & $\begin{array}{l}\mathrm{EC}_{50}(72 \mathrm{~h}) \text { (growth } \\
\text { inhibition) }\end{array}$ & $0.07 \mathrm{mgL}^{-1}$ & [124] \\
\hline \multicolumn{13}{|l|}{ Macrolides } \\
\hline \multirow[t]{2}{*}{ Clarithromycin } & 81103-11-9 & $\begin{array}{l}\text { Po river } \\
\text { water }\end{array}$ & Italy & $\begin{array}{l}\text { SPE- } \\
\text { HPLC-MS/MS }\end{array}$ & 0.3 & $0.49-20.30$ & [24] & Rotifer & B. calyciflorus & $\begin{array}{l}\mathrm{LC}_{50}(24 \mathrm{~h}) \\
\text { (mortality) }\end{array}$ & $35.46 \mathrm{mg} \mathrm{L}^{-1}$ & [124] \\
\hline & & $\begin{array}{l}\text { Lambro river } \\
\text { water }\end{array}$ & & & & 8.31 & & & & & & \\
\hline \multirow[t]{2}{*}{ Clarithromycin } & & STP influent & Taiwan & $\begin{array}{l}\text { SPE-HPLC- } \\
\text { MS/MS }\end{array}$ & $-\dot{t}$ & $59-1433$ & [87] & & & $\begin{array}{l}\mathrm{EC}_{50}(48 \mathrm{~h}) \\
\text { (population growth } \\
\text { inhibition) }\end{array}$ & $12.21 \mathrm{mg} \mathrm{L}^{-1}$ & [124] \\
\hline & & STPeffluent & & & & $12-232$ & & & & & & \\
\hline \multirow[t]{13}{*}{ Clarithromycin } & & $\begin{array}{l}\text { Mankyung } \\
\text { river water }\end{array}$ & South Korea & SPE-LC-MS/MS & 1 & ND $-443( \pm 14)$ & [92] & Crustacean & T. platyurus & $\begin{array}{l}\mathrm{LC}_{50}(24 \mathrm{~h}) \\
\text { (mortality) }\end{array}$ & $94.23 \mathrm{mg} \mathrm{L}^{-1}$ & {$[78]$} \\
\hline & & & & & & & & Fish & O. latipes & $\begin{array}{l}\mathrm{LC}_{50}(96 \mathrm{~h}) \\
\text { (mortality) }\end{array}$ & $>100 \mathrm{mg} \mathrm{L}^{-1}$ & [78] \\
\hline & & & & & & & & Crustacean & T. platyurus & $\begin{array}{l}\mathrm{LC}_{50}(24 \mathrm{~h}) \\
\text { (mortality) }\end{array}$ & $33.64 \mathrm{mg} \mathrm{L}^{-1}$ & [124] \\
\hline & & & & & & & & & D. magna & $\begin{array}{l}\mathrm{EC}_{50}(24 \mathrm{~h}) \\
\text { (immobilization) }\end{array}$ & $25.72 \mathrm{mg} \mathrm{L}^{-1}$ & [124] \\
\hline & & & & & & & & & C. dubia & $\begin{array}{l}\mathrm{EC}_{50}(24 \mathrm{~h}) \\
\text { (immobilization) }\end{array}$ & $18.66 \mathrm{mg} \mathrm{L}^{-1}$ & [124] \\
\hline & & & & & & & & & & $\begin{array}{l}\mathrm{EC}_{50}(7 \mathrm{~d}) \text { (population } \\
\text { growth inhibition) }\end{array}$ & $8.16 \mathrm{mgL}^{-1}$ & [124] \\
\hline & & & & & & & & Algae & P. subcapitata & $\begin{array}{l}\mathrm{EC}_{50}(72 \mathrm{~h}) \text { (growth } \\
\text { inhibition) }\end{array}$ & $0.0020 \mathrm{mgL}^{-1}$ & [124] \\
\hline & & & & & & & & Algae & P. subcapitata & $\begin{array}{l}\mathrm{EC}_{50}(96 \mathrm{~h}) \text { (growth } \\
\text { inhibition) }\end{array}$ & $11 \mu \mathrm{gL}^{-1}$ & [132] \\
\hline & & & & & & & & & & $\begin{array}{l}\text { LOEC (96h) (growth } \\
\text { inhibition) }\end{array}$ & $6.3 \mu \mathrm{gL}^{-1}$ & [132] \\
\hline & & & & & & & & & & $\begin{array}{l}\text { NOEC (96h) (growth } \\
\text { inhibition) }\end{array}$ & $3.1 \mu \mathrm{gL}^{-1}$ & [132] \\
\hline & & & & & & & & Crustacean & D. magna & $\begin{array}{l}\mathrm{EC}_{50}(21 \mathrm{~d}) \\
\text { (reproduction) }\end{array}$ & $40 \mu \mathrm{gL}^{-1}$ & [132] \\
\hline & & & & & & & & & & $\begin{array}{l}\mathrm{LOEC}(21 \mathrm{~d}) \\
\text { (reproduction) }\end{array}$ & $6.3 \mu \mathrm{gL}^{-1}$ & [132] \\
\hline & & & & & & & & & & $\begin{array}{l}\text { NOEC (21 d) } \\
\text { (reproduction) }\end{array}$ & $3.1 \mu \mathrm{gL}^{-1}$ & [132] \\
\hline \multirow[t]{2}{*}{ Erithromycin } & $114-07-8$ & $\begin{array}{l}\text { Po river } \\
\text { water }\end{array}$ & Italy & $\begin{array}{l}\text { SPE- } \\
\text { HPLC-MS/MS }\end{array}$ & 0.3 & $1.40-15.90$ & [24] & Duckweed & Lemna minor & $\begin{array}{l}\mathrm{EC}_{50}(7 \mathrm{~d}) \text { (growth } \\
\text { inhibition) }\end{array}$ & $5.62 \mathrm{mgL}^{-1}$ & [77] \\
\hline & & $\begin{array}{l}\text { Lambro river } \\
\text { water }\end{array}$ & & & & 4.50 & & & & & & \\
\hline \multirow[t]{2}{*}{ Erithromycin } & & STPeffluent & South Korea & SPE-LC-MS/MS & 1.0 & $8.9-294$ & {$[90]$} & Crustacean & T. platyurus & $\begin{array}{l}\mathrm{LC}_{50}(24 \mathrm{~h}) \\
\text { (mortality) }\end{array}$ & $>100 \mathrm{mg} \mathrm{L}^{-1}$ & {$[78]$} \\
\hline & & Surface water & & & & $1.8-4.8$ & & & & & & \\
\hline \multirow[t]{3}{*}{ Erithromycin } & & $\begin{array}{l}\text { Mankyung } \\
\text { river water }\end{array}$ & South Korea & SPE-LC-MS/MS & 1 & ND-137 ( \pm 15$)$ & [92] & Fish & O. latipes & $\begin{array}{l}\mathrm{LC}_{50}(96 \mathrm{~h}) \\
\text { (mortality) }\end{array}$ & $>100 \mathrm{mg} \mathrm{L}^{-1}$ & [78] \\
\hline & & & & & & & & Rotifer & B. calyciflorus & $\begin{array}{l}\mathrm{LC}_{50}(24 \mathrm{~h}) \\
\text { (mortality) }\end{array}$ & $27.53 \mathrm{mgL}^{-1}$ & [124] \\
\hline & & & & & & & & & & $\begin{array}{l}\mathrm{EC}_{50}(48 \mathrm{~h}) \\
\text { (population growth } \\
\text { inhibition) }\end{array}$ & $0.94 \mathrm{mgL}^{-1}$ & [124] \\
\hline
\end{tabular}




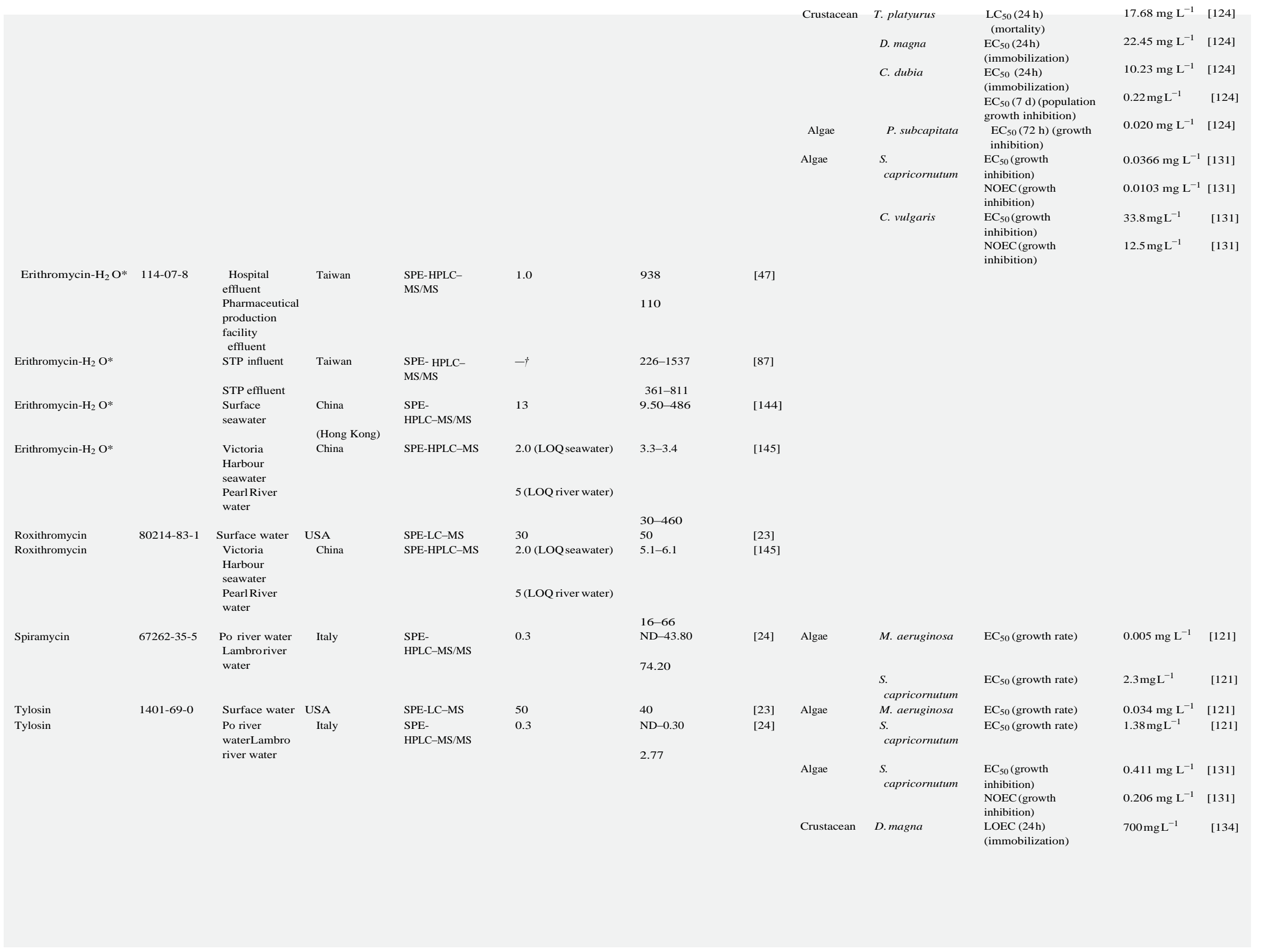




\begin{tabular}{|c|c|c|c|c|c|c|c|c|c|c|c|c|}
\hline Compound & CAS number & Sample & Country & $\begin{array}{l}\text { Analytical } \\
\text { procedure }\end{array}$ & $\operatorname{LOD}\left(\mathrm{ngL}^{-1}\right)$ & $\begin{array}{l}\text { Concentration } \\
\text { reported }\left(\mathrm{ngL}^{-1}\right)\end{array}$ & Ref. & Taxon & Species & $\begin{array}{l}\text { Toxicological } \\
\text { endpoint }\end{array}$ & $\begin{array}{l}\text { Ecotoxicity } \\
\text { data }\end{array}$ & Ref. \\
\hline & & & & & & & & & & $\begin{array}{l}\mathrm{EC}_{50}(48 \mathrm{~h}) \\
\text { (immobilization) }\end{array}$ & $680 \mathrm{mg} \mathrm{L}^{-1}$ & [134] \\
\hline & & & & & & & & & & $\begin{array}{l}\text { NOEC (21 d) } \\
\text { (reproduction) }\end{array}$ & $45 \mathrm{mgL}^{-1}$ & [134] \\
\hline \multicolumn{13}{|l|}{ Sulfonamides } \\
\hline \multirow[t]{6}{*}{ Sulfachloropyridazine } & $80-32-0$ & $\begin{array}{l}\text { STP influent } \\
\text { STP effluent }\end{array}$ & Korea & SPE-LC-MS & 30 & $\begin{array}{l}<30-476 \\
<30-149\end{array}$ & [93] & Bacteria & V. fischeri & $\mathrm{EC}_{50}(15 \mathrm{~min})$ & $26.4 \mathrm{mgL}^{-1}$ & [82] \\
\hline & & & & & & & & Crustacean & D. magna & $\begin{array}{l}\mathrm{EC}_{50}(48 \mathrm{~h}) \\
\text { (immobilization) }\end{array}$ & $375.3 \mathrm{mg} \mathrm{L}^{-1}$ & [82] \\
\hline & & & & & & & & & D. magna & $\begin{array}{l}\mathrm{EC}_{50}(96 \mathrm{~h}) \\
\text { (immobilization) }\end{array}$ & $233.5 \mathrm{mg} \mathrm{L}^{-1}$ & {$[82]$} \\
\hline & & & & & & & & Fish & O. latipes & $\mathrm{LC}_{50}(48 \mathrm{~h})$ & $589.3 \mathrm{mg} \mathrm{L}^{-1}$ & {$[82]$} \\
\hline & & & & & & & & & o. latipes & $\mathrm{LC}_{50}(96 \mathrm{~h})$ & $535.7 \mathrm{mg} \mathrm{L}^{-1}$ & [82] \\
\hline & & & & & & & & Aquatic plant & Lemna minor & $\begin{array}{l}\mathrm{EC}_{50}(48 \mathrm{~h})\left(\mathrm{n}^{\circ} \text { of }\right. \\
\text { green fronds) }\end{array}$ & $2.33 \mathrm{mg} \mathrm{L}^{-1}$ & [133] \\
\hline Sulfadiazine & $68-35-9$ & $\begin{array}{l}\text { Tevere river } \\
\text { water }\end{array}$ & Italy & SPE-LC-MS & 21 (LOQ) & 236 & [143] & Algae & M. aeruginosa & $\begin{array}{l}\mathrm{EC}_{50}(72 \mathrm{~h}) \text { (growth } \\
\text { inhibition) }\end{array}$ & $0.135 \mathrm{mg} \mathrm{L}^{-1}$ & [122] \\
\hline \multirow[t]{10}{*}{ Sulfadiazine } & & Victoria & China & SPE-HPLC-MS & 0.5 (LOQseawater) & ND & [145] & & $S$. & $\mathrm{EC}_{50}(72 \mathrm{~h}$ ) (growth & $7.8 \mathrm{mgL}^{-1}$ & [122] \\
\hline & & $\begin{array}{l}\text { Harbour } \\
\text { seawater }\end{array}$ & & & & & & & capricornutum & inhibition) & & \\
\hline & & $\begin{array}{l}\text { Pearl River } \\
\text { water }\end{array}$ & & & 1 (LOQ river water) & & & & & & & \\
\hline & & & & & & $38-209$ & & & & & & \\
\hline & & & & & & & & Algae & $\begin{array}{l}\text { S. } \\
\text { capricornutum }\end{array}$ & $\begin{array}{l}\mathrm{EC}_{50} \text { (growth } \\
\text { inhibition) }\end{array}$ & $2.19 \mathrm{mgL}^{-1}$ & [131] \\
\hline & & & & & & & & & & $\begin{array}{l}\text { NOEC (growth } \\
\text { inhibition) }\end{array}$ & $<1.00 \mathrm{mgL}^{-1}$ & [131] \\
\hline & & & & & & & & Crustacean & D. magna & $\begin{array}{l}\text { LOEC (24h) } \\
\text { (immobilization) }\end{array}$ & $150 \mathrm{mgL}^{-1}$ & [132] \\
\hline & & & & & & & & & & $\begin{array}{l}\mathrm{EC}_{50}(48 \mathrm{~h}) \\
\text { (immobilization) }\end{array}$ & $221 \mathrm{mgL}^{-1}$ & [132] \\
\hline & & & & & & & & & & $\begin{array}{l}\mathrm{EC}_{50}(21 \mathrm{~d}) \\
\text { (reproduction) }\end{array}$ & $13.7 \mathrm{mgL}^{-1}$ & [132] \\
\hline & & & & & & & & Crustacean & D. magna & $\begin{array}{l}\mathrm{EC}_{50}(48 \mathrm{~h}) \\
\text { (immobilization) }\end{array}$ & $212 \mathrm{mgL}^{-1}$ & [135] \\
\hline Sulfadimethoxine & $122-11-2$ & Surface water & USA & SPE-LC-MS & 50 & 60 & [23] & Bacteria & V. fischeri & $\mathrm{EC}_{50}(15 \mathrm{~min})$ & $>500 \mathrm{mg} \mathrm{L}^{-1}$ & {$[82]$} \\
\hline Sulfadimethoxine & & Groundwater & USA & SPE-LC-MS/MS & 30 & $46-68$ & [27] & Crustacean & D. magna & $\begin{array}{l}\mathrm{EC}_{50}(48 \mathrm{~h}) \\
\text { (immobilization) }\end{array}$ & $248.0 \mathrm{mg} \mathrm{L}^{-1}$ & {$[82]$} \\
\hline \multirow[t]{2}{*}{ Sulfadimethoxine } & & $\begin{array}{l}\text { Hospital } \\
\text { effluent }\end{array}$ & Taiwan & $\begin{array}{l}\text { SPE- } \\
\text { HPLC-MS/MS }\end{array}$ & 1.0 & ND & [47] & & D. magna & $\begin{array}{l}\mathrm{EC}_{50}(96 \mathrm{~h}) \\
\text { (immobilization) }\end{array}$ & $204.5 \mathrm{mg} \mathrm{L}^{-1}$ & {$[82]$} \\
\hline & & $\begin{array}{l}\text { Pharmaceutical } \\
\text { production } \\
\text { facility } \\
\text { effluent }\end{array}$ & & & & 0.8 & & & & & & \\
\hline \multirow[t]{4}{*}{ Sulfadimethoxine } & & STP influent & Luxembourg & SPE-LC-MS/MS & 0.3 & $0.3-26$ & [89] & Fish & O. latipes & $\mathrm{LC}_{50}(48 \mathrm{~h})$ & $>100 \mathrm{mg} \mathrm{L}^{-1}$ & {$[82]$} \\
\hline & & STPeffluent & & & & $0.3-9$ & & & & & & \\
\hline & & $\begin{array}{l}\text { Alzette river } \\
\text { water }\end{array}$ & & & & $0.3-3$ & & & & & & \\
\hline & & $\begin{array}{l}\text { Mess river } \\
\text { water }\end{array}$ & & & & $<0.3$ & & & & & & \\
\hline \multirow[t]{3}{*}{ Sulfadimethoxine } & & STP influent & Korea & SPE-LC-MS & 10 & $<10-213$ & [93] & & O. latipes & $\mathrm{LC}_{50}(96 \mathrm{~h})$ & $>100 \mathrm{mg} \mathrm{L}^{-1}$ & {$[82]$} \\
\hline & & STPeffluent & & & & $<10-70$ & & & & & & \\
\hline & & $\begin{array}{l}\text { Han river } \\
\text { water }\end{array}$ & & & & $<10-13$ & & & & & & \\
\hline Sulfadimethoxine & & $\begin{array}{l}\text { Tevere river } \\
\text { water }\end{array}$ & Italy & SPE-LC-MS & 8 & 28 & [143] & Algae & $\begin{array}{l}\text { S. } \\
\text { capricornutum }\end{array}$ & $\begin{array}{l}\mathrm{EC}_{50} \text { (growth } \\
\text { inhibition) }\end{array}$ & $2.30 \mathrm{mg} \mathrm{L}^{-1}$ & [131] \\
\hline
\end{tabular}




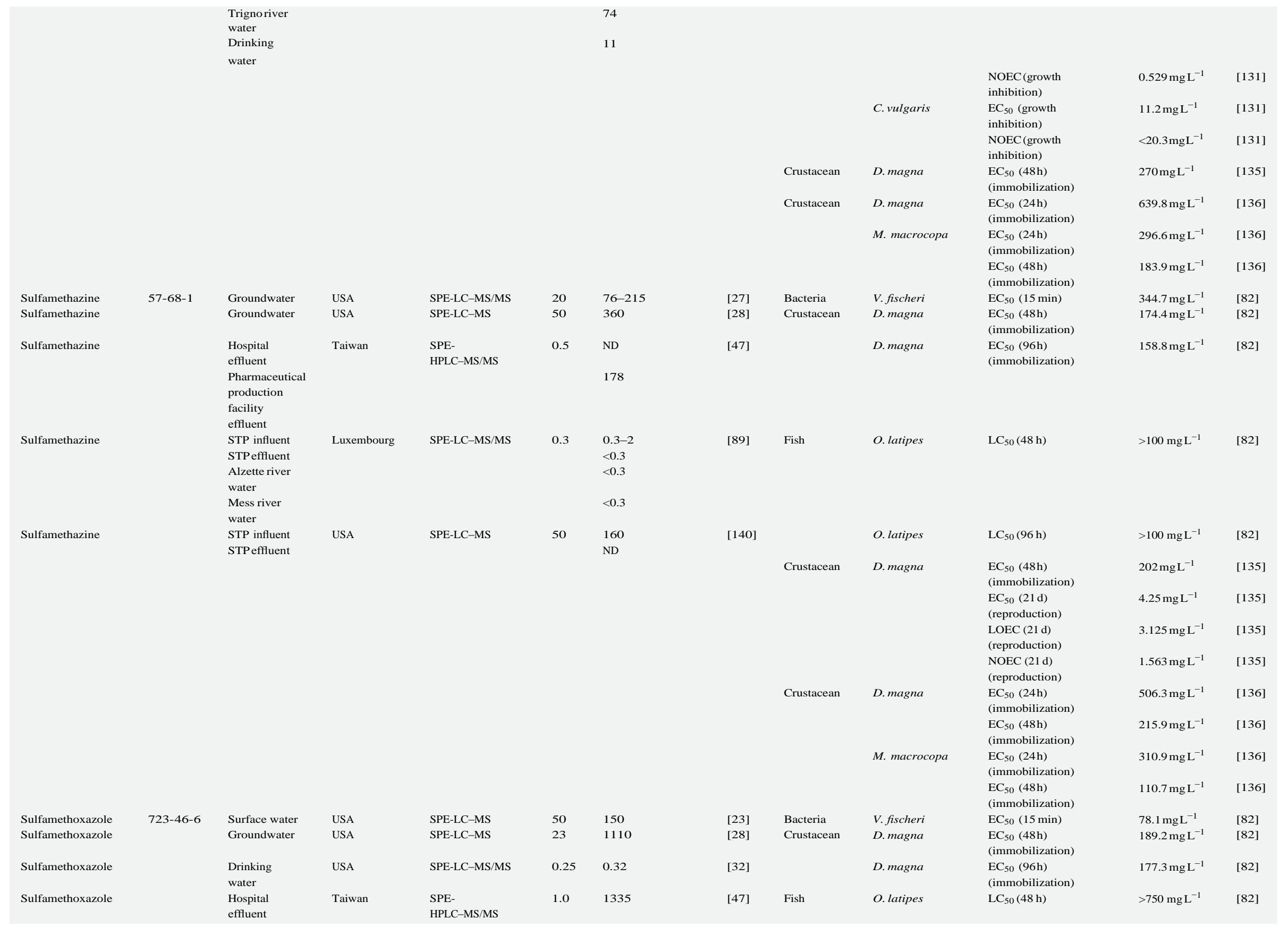




\begin{tabular}{|c|c|c|c|c|c|c|c|c|c|c|c|c|}
\hline Compound & CAS number & Sample & Country & $\begin{array}{l}\text { Analytical } \\
\text { procedure }\end{array}$ & $\operatorname{LOD}\left(\mathrm{ngL}^{-1}\right)$ & $\begin{array}{l}\text { Concentration } \\
\text { reported }\left(\mathrm{ngL}^{-1}\right)\end{array}$ & Ref. & Taxon & Species & $\begin{array}{l}\text { Toxicological } \\
\text { endpoint }\end{array}$ & $\begin{array}{l}\text { Ecotoxicity } \\
\text { data }\end{array}$ & Ref. \\
\hline & & $\begin{array}{l}\text { Pharmaceutical } \\
\text { production } \\
\text { facility } \\
\text { effluent }\end{array}$ & & & & 34 & & & & & & \\
\hline \multirow[t]{2}{*}{ Sulfamethoxazole } & & STP influent & Taiwan & $\begin{array}{l}\text { SPE-HPLC- } \\
\text { MS/MS }\end{array}$ & $-t$ & $179-1760$ & [87] & & O. latipes & $\mathrm{LC}_{50}(96 \mathrm{~h})$ & $562.5 \mathrm{mg} \mathrm{L}^{-1}$ & [82] \\
\hline & & STPeffluent & & & & $47-964$ & & & & & & \\
\hline \multirow[t]{4}{*}{ Sulfamethoxazole } & & STP influent & Luxembourg & SPE-LC-MS/MS & 0.3 & $13-155$ & [89] & Cnidarian & $\begin{array}{l}\text { Hydra } \\
\text { attenuata }\end{array}$ & $\begin{array}{l}\mathrm{LC}_{50}(96 \mathrm{~h}) \\
\text { (morphology) }\end{array}$ & $>100 \mathrm{mg} \mathrm{L}^{-1}$ & [98] \\
\hline & & STPeffluent & & & & $4-39$ & & & & & & \\
\hline & & $\begin{array}{l}\text { Alzette river } \\
\text { water }\end{array}$ & & & & $1-22$ & & & & & & \\
\hline & & $\begin{array}{l}\text { Mess river } \\
\text { water }\end{array}$ & & & & $0.3-5$ & & & & & & \\
\hline \multirow[t]{2}{*}{ Sulfamethoxazole } & & STPeffluent & South Korea & SPE-LC-MS/MS & 1.0 & $3.8-407$ & [90] & & & $\begin{array}{l}\text { LOEC (96h) } \\
\text { (morphology) }\end{array}$ & $10 \mathrm{mgL}^{-1}$ & [98] \\
\hline & & Surface water & & & & $1.7-36$ & & & & & & \\
\hline \multirow[t]{3}{*}{ Sulfamethoxazole } & & STP influent & Korea & SPE-LC-MS & 5 & 156-984 & [93] & & & $\begin{array}{l}\text { NOEC (96h) } \\
\text { (morphology) }\end{array}$ & $5 \mathrm{mgL}^{-1}$ & [98] \\
\hline & & STPeffluent & & & & $25-492$ & & & & & & \\
\hline & & $\begin{array}{l}\text { Han river } \\
\text { water }\end{array}$ & & & & $<5-82$ & & & & & & \\
\hline \multirow[t]{4}{*}{ Sulfamethoxazole } & & STP influent & USA & $\begin{array}{l}\text { SPE- } \\
\text { HPLC-MS/MS }\end{array}$ & 12 & ND-1000 & [138] & Bacteria & V. fischeri & $\begin{array}{l}\mathrm{EC}_{50}(30 \mathrm{~min}) \\
\text { (luminescnce) }\end{array}$ & $23.3 \mathrm{mgL}^{-1}$ & [124] \\
\hline & & STPeffluent & & & & 310 & & & & & & \\
\hline & & $\begin{array}{l}\text { Hospital } \\
\text { effluent }\end{array}$ & & & & ND-2100 & & & & & & \\
\hline & & $\begin{array}{l}\text { Rio Grande } \\
\text { river water }\end{array}$ & & & & ND-300 & & & & & & \\
\hline \multirow[t]{2}{*}{ Sulfamethoxazole } & & STP influent & USA & SPE-LC-MS & 50 & 300 & [140] & Rotifer & B. calycifforus & $\begin{array}{l}\mathrm{LC}_{50}(24 \mathrm{~h}) \\
\text { (mortality) }\end{array}$ & $26.27 \mathrm{mg} \mathrm{L}^{-1}$ & [124] \\
\hline & & STPeffluent & & & & 200 & & & & & & \\
\hline \multirow[t]{2}{*}{ Sulfamethoxazole } & & STP influent & Sweden & SPE-LC-MS & 80 (LOQ) & $<80-674$ & [141] & & & $\begin{array}{l}\mathrm{EC}_{50}(48 \mathrm{~h}) \\
\text { (population growth } \\
\text { inhibition) }\end{array}$ & $9.63 \mathrm{mg} \mathrm{L}^{-1}$ & [124] \\
\hline & & STP effluent & & & & $<80-304$ & & & & & & \\
\hline \multirow[t]{2}{*}{ Sulfamethoxazole } & & $\begin{array}{l}\text { Tevere river } \\
\text { water }\end{array}$ & Italy & SPE-LC-MS & 9 & 402 & [143] & Crustacean & T. platyurus & $\begin{array}{l}\mathrm{LC}_{50}(24 \mathrm{~h}) \\
\text { (mortality) }\end{array}$ & $35.36 \mathrm{mg} \mathrm{L}^{-1}$ & [124] \\
\hline & & $\begin{array}{l}\text { Drinking } \\
\text { water }\end{array}$ & & & & $13-80$ & & & & & & \\
\hline \multirow[t]{7}{*}{ Sulfamethoxazole } & & $\begin{array}{l}\text { Victoria } \\
\text { Harbour } \\
\text { seawater }\end{array}$ & China & SPE-HPLC-MS & 0.8 (LOQseawater) & ND & [145] & & D. magna & $\begin{array}{l}\mathrm{EC}_{50}(24 \mathrm{~h}) \\
\text { (immobilization) }\end{array}$ & $25.20 \mathrm{mg} \mathrm{L}^{-1}$ & [124] \\
\hline & & $\begin{array}{l}\text { Pearl River } \\
\text { water }\end{array}$ & & & 1 (LOQ river water) & & & & & & & \\
\hline & & & & & & $37-134$ & & & & & & \\
\hline & & & & & & & & & C. dubia & $\begin{array}{l}\mathrm{EC}_{50}(24 \mathrm{~h}) \\
\text { (immobilization) }\end{array}$ & $15.51 \mathrm{mg} \mathrm{L}^{-1}$ & [124] \\
\hline & & & & & & & & & & $\begin{array}{l}\mathrm{EC}_{50}(7 \mathrm{~d}) \text { (population } \\
\text { growth inhibition) }\end{array}$ & $0.21 \mathrm{mgL}^{-1}$ & [124] \\
\hline & & & & & & & & Algae & P. subcapitata & $\begin{array}{l}\mathrm{EC}_{50}(72 \mathrm{~h}) \text { (growth } \\
\text { inhibition) }\end{array}$ & $0.52 \mathrm{mgL}^{-1}$ & [124] \\
\hline & & & & & & & & Algae & $\begin{array}{l}S . \\
\text { capricornutum }\end{array}$ & $\begin{array}{l}\mathrm{EC}_{50} \text { (growth } \\
\text { inhibition) }\end{array}$ & $1.53 \mathrm{mg} \mathrm{L}^{-1}$ & [131] \\
\hline
\end{tabular}




\begin{tabular}{|c|c|c|c|c|c|c|c|c|c|c|c|c|}
\hline & & & & & & & & & & $\begin{array}{l}\text { NOEC (growth } \\
\text { inhibition) }\end{array}$ & $0.614 \mathrm{mg} \mathrm{L}^{-1}$ & [131] \\
\hline & & & & & & & & Crustacean & D. magna & $\begin{array}{l}\mathrm{EC}_{50}(48 \mathrm{~h}) \\
\text { (immobilization) }\end{array}$ & $123.1 \mathrm{mg} \mathrm{L}^{-1}$ & [136] \\
\hline & & & & & & & & & M. тастосора & $\begin{array}{l}\mathrm{EC}_{50}(24 \mathrm{~h}) \\
\text { (immobilization) }\end{array}$ & $84.9 \mathrm{mgL}^{-1}$ & [136] \\
\hline & & & & & & & & & & $\begin{array}{l}\mathrm{EC}_{50}(48 \mathrm{~h}) \\
\text { (immobilization) }\end{array}$ & $70.4 \mathrm{mgL}^{-1}$ & [136] \\
\hline \multirow[t]{5}{*}{ Sulfapyridine } & 7238-91-7 & $\begin{array}{l}\text { Tevere river } \\
\text { water }\end{array}$ & Italy & SPE-LC-MS & 12 & $<12-121$ & [143] & Cnidarian & $\begin{array}{l}\text { Hydra } \\
\text { attenuata }\end{array}$ & $\begin{array}{l}\mathrm{LC}_{50}(96 \mathrm{~h}) \\
\text { (morphology) }\end{array}$ & $>100 \mathrm{mg} \mathrm{L}^{-1}$ & {$[98]$} \\
\hline & & $\begin{array}{l}\text { Trigno river } \\
\text { water }\end{array}$ & & & & 66 & & & & & & \\
\hline & & & & & & & & & & $\begin{array}{l}\mathrm{EC}_{50}(96 \mathrm{~h}) \\
\text { (morphology) }\end{array}$ & $21.61 \mathrm{mg} \mathrm{L}^{-1}$ & {$[98]$} \\
\hline & & & & & & & & & & $\begin{array}{l}\text { LOEC (96h) } \\
\text { (morphology) }\end{array}$ & $5 \mathrm{mgL}^{-1}$ & {$[98]$} \\
\hline & & & & & & & & & & $\begin{array}{l}\text { NOEC (96h) } \\
\text { (morphology) }\end{array}$ & $1 \mathrm{mgL}^{-1}$ & {$[98]$} \\
\hline \multirow[t]{3}{*}{ Sulfathiazole } & 72-14-0 & STP influent & Luxembourg & SPE-LC-MS/MS & 0.3 & $0.3-2$ & [89] & Bacteria & V. fischeri & $\mathrm{EC}_{50}(15 \mathrm{~min})$ & $>1000 \mathrm{mgL}^{-1}$ & {$[82]$} \\
\hline & & $\begin{array}{l}\text { STPeffluent } \\
\text { Alzette river } \\
\text { water }\end{array}$ & & & & $\begin{array}{l}<0.3 \\
<0.3\end{array}$ & & & & & & \\
\hline & & $\begin{array}{l}\text { Mess river } \\
\text { water }\end{array}$ & & & & $0.3-2$ & & & & & & \\
\hline \multirow[t]{10}{*}{ Sulfathiazole } & & STP influent & Korea & SPE-LC-MS & 30 & $<30-531$ & [93] & Crustacean & D. magna & $\begin{array}{l}\operatorname{LOEC}(21 \mathrm{~d}) \\
\text { (reproduction) }\end{array}$ & $35 \mathrm{mgL}^{-1}$ & [136] \\
\hline & & STPeffluent & & & & $<30$ & & & & & & \\
\hline & & & & & & & & & & $\begin{array}{l}\text { NOEC (21 d) } \\
\text { (reproduction) }\end{array}$ & $11 \mathrm{mgL}^{-1}$ & [136] \\
\hline & & & & & & & & Crustacean & D. magna & $\begin{array}{l}\mathrm{EC}_{50}(48 \mathrm{~h}) \\
\text { (immobilization) }\end{array}$ & $149.3 \mathrm{mg} \mathrm{L}^{-1}$ & {$[82]$} \\
\hline & & & & & & & & & D. magna & $\begin{array}{l}\mathrm{EC}_{50}(96 \mathrm{~h}) \\
\text { (immobilization) }\end{array}$ & $85.4 \mathrm{mgL}^{-1}$ & {$[82]$} \\
\hline & & & & & & & & Fish & O. latipes & $\mathrm{LC}_{50}(48 \mathrm{~h})$ & $>500 \mathrm{mg} \mathrm{L}^{-1}$ & {$[82]$} \\
\hline & & & & & & & & & O. latipes & $\mathrm{LC}_{50}(96 \mathrm{~h})$ & $>500 \mathrm{mg} \mathrm{L}^{-1}$ & {$[82]$} \\
\hline & & & & & & & & Crustacean & D. magna & $\begin{array}{l}\mathrm{EC}_{50}(24 \mathrm{~h}) \\
\text { (immobilization) }\end{array}$ & $616.7 \mathrm{mg} \mathrm{L}^{-1}$ & [136] \\
\hline & & & & & & & & & M. macrocopa & $\begin{array}{l}\mathrm{EC}_{50}(24 \mathrm{~h}) \\
\text { (immobilization) }\end{array}$ & $430.1 \mathrm{mg} \mathrm{L}^{-1}$ & [136] \\
\hline & & & & & & & & & & $\begin{array}{l}\mathrm{EC}_{50}(48 \mathrm{~h}) \\
\text { (immobilization) }\end{array}$ & $391.1 \mathrm{mg} \mathrm{L}^{-1}$ & [136] \\
\hline \multirow{9}{*}{$\begin{array}{l}\text { Tetracyclines } \\
\text { Chlortetracycline } \\
\text { Chlortetracycline }\end{array}$} & & & & & & & & & & & & \\
\hline & $57-62-5$ & Surface water & USA & SPE-LC-MS & 100 & 420 & [23] & Algae & M. aeruginosa & $\mathrm{EC}_{50}$ (growth rate) & $0.05 \mathrm{mgL}^{-1}$ & [121] \\
\hline & & $\begin{array}{l}\text { Hospital } \\
\text { effluent }\end{array}$ & Taiwan & $\begin{array}{l}\text { SPE- } \\
\text { HPLC-MS/MS }\end{array}$ & 5.0 & ND & [47] & & $\begin{array}{l}S . \\
\text { capricornutum }\end{array}$ & $\mathrm{EC}_{50}$ (growth rate) & $3.1 \mathrm{mgL}^{-1}$ & [121] \\
\hline & & $\begin{array}{l}\text { Pharmaceutical } \\
\text { production } \\
\text { facility } \\
\text { effluent }\end{array}$ & & & & 5.7 & & & & & & \\
\hline & & & & & & & & Bacteria & V. fischeri & $\begin{array}{l}\mathrm{EC}_{50}(15 \mathrm{~min}) \\
\text { (luminescence) }\end{array}$ & $13.0 \mathrm{mgL}^{-1}$ & [136] \\
\hline & & & & & & & & Crustacean & D. magna & $\begin{array}{l}\mathrm{EC}_{50}(24 \mathrm{~h}) \\
\text { (immobilization) }\end{array}$ & $380.1 \mathrm{mg} \mathrm{L}^{-1}$ & [136] \\
\hline & & & & & & & & & & $\begin{array}{l}\mathrm{EC}_{50}(48 \mathrm{~h}) \\
\text { (immobilization) }\end{array}$ & $225 \mathrm{mg} \mathrm{L}^{-1}$ & [136] \\
\hline & & & & & & & & & M. macrocopa & $\begin{array}{l}\mathrm{EC}_{50}(24 \mathrm{~h}) \\
\text { (immobilization) }\end{array}$ & $515 \mathrm{mgL}^{-1}$ & [136] \\
\hline & & & & & & & & & & $\begin{array}{l}\mathrm{EC}_{50}(48 \mathrm{~h}) \\
\text { (immobilization) }\end{array}$ & $272 \mathrm{mg} \mathrm{L}^{-1}$ & [136] \\
\hline
\end{tabular}




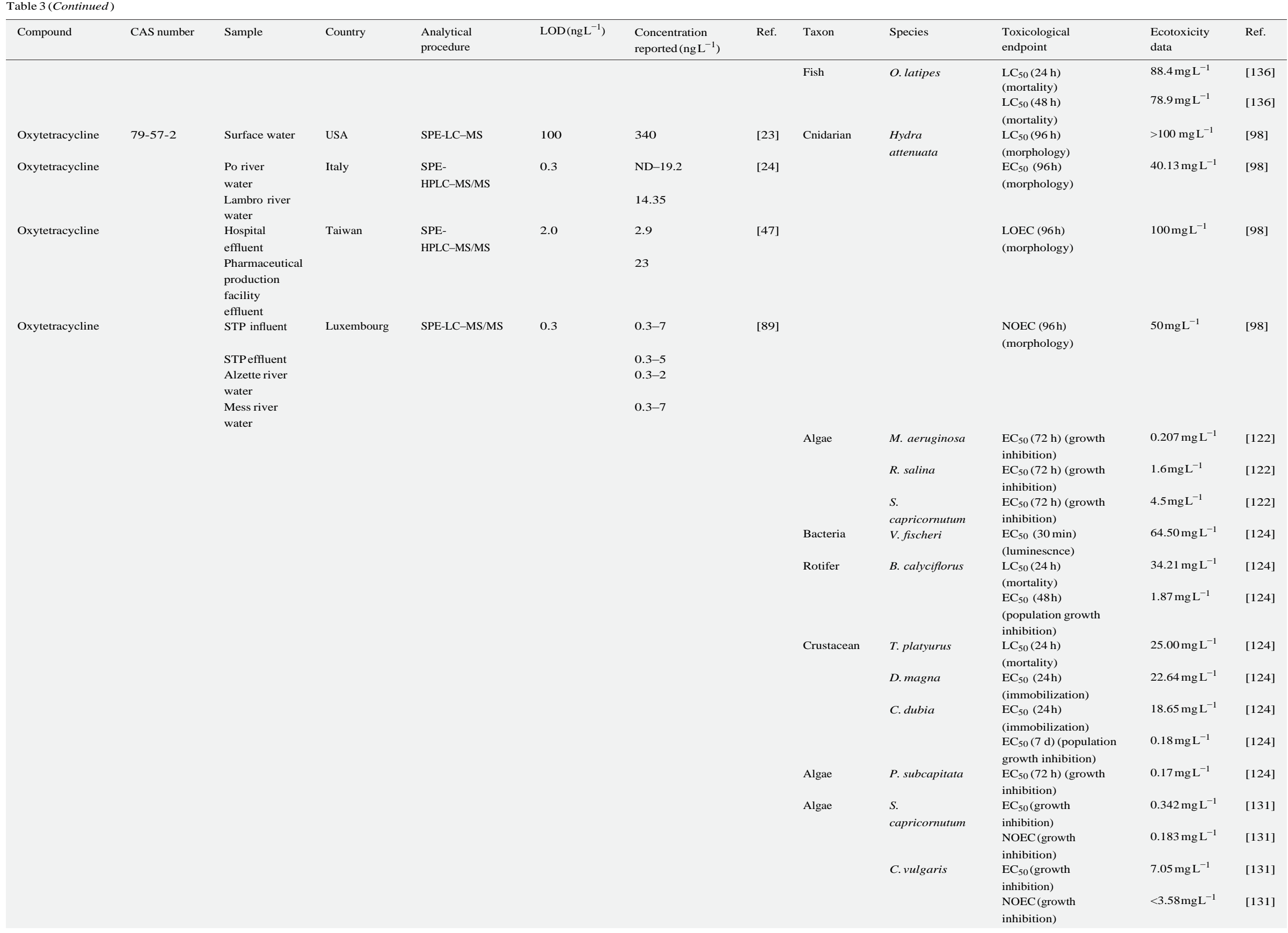




\begin{tabular}{|c|c|c|c|c|c|c|c|c|c|c|c|c|}
\hline & & & & & & & & Aquatic plant & Lemna minor & $\begin{array}{l}\mathrm{EC}_{50}(48 \mathrm{~h})\left(\mathrm{n}^{\circ} \text { of }\right. \\
\text { green fronds) }\end{array}$ & $4.92 \mathrm{mgL}^{-1}$ & [133] \\
\hline & & & & & & & & Crustacean & D. magna & $\begin{array}{l}\text { LOEC (48h) } \\
\text { (immobilization) }\end{array}$ & $100 \mathrm{mgL}^{-1}$ & [134] \\
\hline & & & & & & & & & & $\begin{array}{l}\mathrm{EC}_{50}(21 \mathrm{~d}) \\
\text { (reproduction) }\end{array}$ & $46.2 \mathrm{mgL}^{-1}$ & [134] \\
\hline & & & & & & & & Bacteria & V. fischeri & $\begin{array}{l}\mathrm{EC}_{50}(15 \mathrm{~min}) \\
\text { (luminescence) }\end{array}$ & $87.0 \mathrm{mgL}^{-1}$ & [136] \\
\hline & & & & & & & & Crustacean & D. magna & $\begin{array}{l}\mathrm{EC}_{50}(24 \mathrm{~h}) \\
\text { (immobilization) }\end{array}$ & $831.6 \mathrm{mg} \mathrm{L}^{-1}$ & [136] \\
\hline & & & & & & & & & & $\begin{array}{l}\mathrm{EC}_{50}(48 \mathrm{~h}) \\
\text { (immobilization) }\end{array}$ & $621.2 \mathrm{mg} \mathrm{L}^{-1}$ & [136] \\
\hline & & & & & & & & & M. macrocopa & $\begin{array}{l}\mathrm{EC}_{50}(24 \mathrm{~h}) \\
\text { (immobilization) }\end{array}$ & $137.1 \mathrm{mg} \mathrm{L}^{-1}$ & [136] \\
\hline & & & & & & & & & & $\begin{array}{l}\mathrm{EC}_{50}(48 \mathrm{~h}) \\
\text { (immobilization) }\end{array}$ & $126.7 \mathrm{mg} \mathrm{L}^{-1}$ & [136] \\
\hline & & & & & & & & Fish & O. latipes & $\begin{array}{l}\mathrm{LC}_{50}(24 \mathrm{~h}) \\
\text { (mortality) }\end{array}$ & $215.4 \mathrm{mg} \mathrm{L}^{-1}$ & [136] \\
\hline & & & & & & & & & & $\begin{array}{l}\mathrm{LC}_{50}(48 \mathrm{~h}) \\
\text { (mortality) }\end{array}$ & $110.1 \mathrm{mg} \mathrm{L}^{-1}$ & [136] \\
\hline Tetracycline & $60-54-8$ & Surface water & USA & SPE-LC-MS & 100 & 110 & [23] & Duckweed & Lemna minor & $\begin{array}{l}\mathrm{EC}_{50}(7 \mathrm{~d}) \text { (growth } \\
\text { inhibition) }\end{array}$ & $1.06 \mathrm{mgL}^{-1}$ & [77] \\
\hline Tetracycline & & $\begin{array}{l}\text { Hospital } \\
\text { effluent }\end{array}$ & Taiwan & $\begin{array}{l}\text { SPE- } \\
\text { HPLC-MS/MS }\end{array}$ & 2.0 & 89 & [47] & Algae & M. aeruginosa & $\mathrm{EC}_{50}$ (growth rate) & $0.09 \mathrm{mgL}^{-1}$ & [121] \\
\hline & & $\begin{array}{l}\text { Pharmaceutical } \\
\text { production } \\
\text { facility } \\
\text { effluent }\end{array}$ & & & & 25 & & & & & & \\
\hline Tetracycline & & STP influent & Taiwan & $\begin{array}{l}\text { SPE-HPLC- } \\
\text { MS/MS }\end{array}$ & $-t$ & $46-234$ & [87] & & $\begin{array}{l}S . \\
\text { capricornutum }\end{array}$ & $\mathrm{EC}_{50}$ (growth rate) & $2.2 \mathrm{mgL}^{-1}$ & [121] \\
\hline & & STPeffluent & & & & $16-38$ & & & & & & \\
\hline Tetracycline & & STP influent & Luxembourg & SPE-LC-MS/MS & 0.3 & $0.3-85$ & [89] & Crustacean & D. magna & $\begin{array}{l}\text { NOEC (48h) } \\
\text { (immobilization) }\end{array}$ & $340 \mathrm{mgL}^{-1}$ & [134] \\
\hline & & STP effluent & & & & $0.3-24$ & & & & & & \\
\hline & & $\begin{array}{l}\text { Alzette river } \\
\text { water }\end{array}$ & & & & $0.3-8$ & & & & & & \\
\hline & & $\begin{array}{l}\text { Mess river } \\
\text { water }\end{array}$ & & & & $0.3-7$ & & & & & & \\
\hline Tetracycline & & STP influent & USA & SPE-LC-MS & 50 & 520 & [140] & & & $\begin{array}{l}\mathrm{EC}_{50}(21 \mathrm{~d}) \\
\text { (reproduction) }\end{array}$ & $44.8 \mathrm{mg} \mathrm{L}^{-1}$ & [134] \\
\hline & & STPeffluent & & & & 170 & & & & & & \\
\hline Tetracycline & & $\begin{array}{l}\text { Surface } \\
\text { seawater }\end{array}$ & $\begin{array}{l}\text { China } \\
\text { (Hong Kong) }\end{array}$ & $\begin{array}{l}\text { SPE- } \\
\text { HPLC-MS/MS }\end{array}$ & 13 & $<13-122$ & [144] & & & & & \\
\hline Others & & & & & & & & & & & & \\
\hline Chloramphenicol & $85666-84-8$ & $\begin{array}{l}\text { Victoria } \\
\text { Harbour } \\
\text { seawater }\end{array}$ & China & SPE-HPLC-MS & 4.1 (LOQ seawater) & ND & [145] & & & & & \\
\hline & & $\begin{array}{l}\text { Pearl River } \\
\text { water }\end{array}$ & & & 5 (LOQ river water) & & & & & & & \\
\hline Metronidazole & 99616-64-5 & STP influent & Taiwan & $\begin{array}{l}\text { SPE-HPLC- } \\
\text { MS/MS }\end{array}$ & $-t$ & $\begin{array}{l}41-127 \\
1-294\end{array}$ & [87] & Crustacean & D. magna & $\begin{array}{l}\text { LOEC(48h) } \\
\text { (immobilization) }\end{array}$ & $1000 \mathrm{mg} \mathrm{L}^{-1}$ & [134] \\
\hline & & STPeffluent & & & & $10-126$ & & & & $\begin{array}{l}\text { NOEC (21 d) } \\
\text { (reproduction) }\end{array}$ & $250 \mathrm{mgL}^{-1}$ & [134] \\
\hline Trimethoprim & $738-70-5$ & Surface water & USA & SPE-LC-MS & 30 & 150 & [23] & Bacteria & V. fischeri & $\mathrm{EC}_{50}(15 \mathrm{~min})$ & $176.7 \mathrm{mgL}^{-1}$ & {$[82]$} \\
\hline Trimethoprim & & $\begin{array}{l}\text { Drinking } \\
\text { water }\end{array}$ & USA & SPE-LC-MS/MS & 0.25 & $<0.25$ & [32] & Crustacean & D. magna & $\begin{array}{l}\mathrm{EC}_{50}(48 \mathrm{~h}) \\
\text { (immobilization) }\end{array}$ & $167.4 \mathrm{mg} \mathrm{L}^{-1}$ & {$[82]$} \\
\hline
\end{tabular}




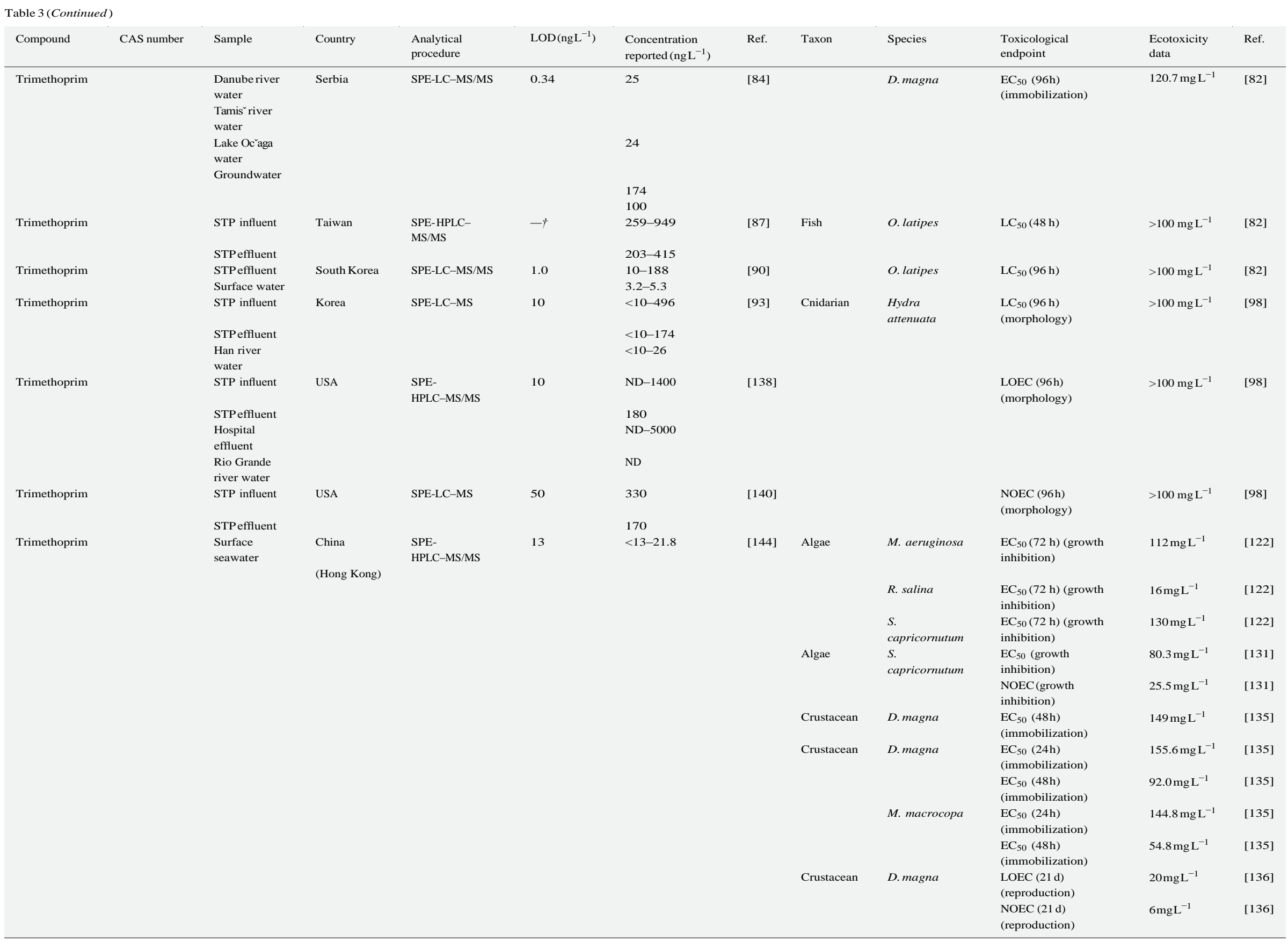

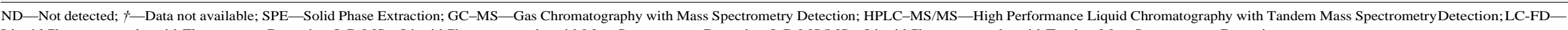
LiquidChromatography with Fluorescence Detection;LC-MS - Liquid Chromatography with Mass Spectrometry Detection;LC-MS/MS - LiquidChromatography with Tandem Mass Spectrometry Detection. 
4.6 and $40 \mathrm{mg} \mathrm{L}^{-1}$ respectively [134], while sulfamethazine had an $\mathrm{EC}_{50}$ of $202 \mathrm{mg} \mathrm{L}^{-1}$ [135]. Reproduction was also impaired by oxytetracycline, sulfadiazine, tetracycline and tiamulin at concentrations between 5 and $50 \mathrm{mg} \mathrm{L}^{-1}$. Oxolinic acid, streptomycin and tylosin were revealed to be lethal after long-term exposure [134]. Chronic toxicity effects were also observed on the reproduction of the crustacean D. magna, when were exposed to levofloxacin and clarithromycin, with $\mathrm{EC}_{50}$ values of 340 and $40 \mu \mathrm{g} \mathrm{L}^{-1}$, respec- tively [132]. Eleven commonly used antibiotics were evaluated in organisms belonging to different trophic levels ( $V$. fischeri, D. magna, Moina macrocopa, and $O$. latipes). Neomycin showed sig- nificant effects on D. magna $\left(\mathrm{EC}_{50}=42.1 \mathrm{mg} \mathrm{L}-1\right)$. Macrocopa $\left(\mathrm{EC}_{50}=34.1 \mathrm{mg} \mathrm{L}^{-1}\right)$ and $O$. latipes $\left(\mathrm{LC}_{50}=80.8 \mathrm{mg} \mathrm{L}^{-1}\right)$ while beta- lactam antibiotics (ampicillin and amoxycillin) were the less toxic to all tested organisms [136]. Neomycin showed chronic toxicity by affecting the reproduction and adult survival of D. magna and M. macrocopa even at low $\mathrm{mg} \mathrm{L}^{-1}$ levels of exposure ( $\mathrm{EC}_{50}$ s of 0.09 and

$0.74 \mathrm{mg} \mathrm{L}^{-1}$, respectively). Other pharmaceuticals such as sulfathia- zole, trimethoprim and enrofloxacin also showed similar effects on those two cladocerans in a dose-dependent manner. Luminescence inhibition on $V$. fischeri occurred after irradiation of tetracycline, proving that photolytic products become more toxic than the par- ent compound [137]. Antibiotics belonging to different classes have been found in different aquatic environments (Table 3). Lincomycin was detected in hospital and livestock effluents at concentrations of 2 and $6.6 \mu \mathrm{g} \mathrm{L}^{-1}$, respectively [138]. Fluorquinolone antibiotics as ciprofloxacin were found in hospital effluents [138,139] at val- ues between 2 and $11 \mu \mathrm{g}$ $\mathrm{L}^{-1}$, in STP influents $\left(90-1000 \mathrm{ng} \mathrm{L}^{-1}\right)$ and effluents $\left(<6-310 \mathrm{ng} \mathrm{L}^{-1}\right)$ [138-141] as well as in surface waters, i.e. the Lambro river (Italy) (14.36 ng L ${ }^{-1}$ ) [24] and Mon- dego river (Portugal) (79.6-119.2 ng $\mathrm{L}^{-1}$ ) [142]. Enrofloxacin, a fluorquinolone used by the veterinary medicine, was detected in STP influents $\left(121.8-447.1 \mathrm{ng} \mathrm{L}^{-1}\right)$ and effluents (53.7-270 $\mathrm{ng} \mathrm{L}^{-1}$ ) in Portugal [139] and the US [140] as well as in surface waters from the Mondego river (Portugal) (67.0-102.5 ng $\mathrm{L}^{-1}$ ) [142]. Sulfon- amides have been found in several aquatic systems as STP influents and effluents [138,140,141], surface waters [23,143], groundwa- ters [27,28] and drinking waters [143] in concentrations ranging from $\mathrm{ng} \mathrm{L}^{-1}$ to a few $\mu \mathrm{g} \mathrm{L}^{-1}$. Regarding the tetracyclines, oxyte- tracycline was detected in the Po and Lambro rivers (Italy) at concentrations up to 248.90 and $24.40 \mathrm{ng} \mathrm{L}^{-1}$ respectively [24], in combination with tetracycline [140] in American STP influent (47 $\mu \mathrm{g}$ $\left.\mathrm{L}^{-1}\right)$ and effluent $\left(4.2 \mu \mathrm{g} \mathrm{L}^{-1}\right)$ [140] and in surface waters $\left(340 \mathrm{ng} \mathrm{L}^{-1}\right)$ [23]. In addition to aquatic systems, antibiotics belong- ing to the fluorquinolones class have also been found in sediments at concentrations that can reach $4.8 \mathrm{mg} \mathrm{kg}^{-1}$ [141]. This finding may represent a potential risk warning of persistence in the environ- ment.

\subsection{Sex hormones}

Sex hormones are extremely active biological compounds producing intense therapeutic effects even at very low doses. Today, they are commonly prescribed as oral contraceptives thus indirectly contributing to the increase in environmental concentrations [52,108]. Estrogens are the sex hormones most commonly found in the environment. These can exist as either natural or synthetic substances, mimicking the effects of endogenous estro- gens as endocrine-disrupting compounds (EDCs) [146] through binding to specific receptors common to non-target organisms (invertebrates, fish, reptiles, birds and mammals) [108]. In fish, estrogens are involved in several physiological functions includ- ing: (i) vitellogenin synthesis; (ii) vitelline envelope (eggshell) protein production; (iii) gonadal differentiation; (iv) development of secondary sexual characteristics; (v) gonadotropin secretion;

(vi) synthesis of estrogen receptors; (vii) pheromonal communi- cation; (viii) bone formation; and (ix) calcium homeostasis [146]. The enhanced production of the vitellogenin found in the blood of male and juvenile fish provides a useful biomarker of aquatic con-tamination by compounds with estrogenic activity [52,146]. Wild fish (roach; Rutilus rutilus) exposed to such compounds in UK rivers receiving STP effluents suffered adverse reproductive effects. Malefish were shown to be intersex, i.e. they had simultaneous male and female gonadal characteristics besides a high plasma vitellogeninconcentration [147]. Ethinylestradiol $\left(E_{2}\right)$ is a synthetic estrogen found in oral contraceptive pills with marked estrogenic effects in fish. The life-cycle exposure of fathead minnows to $\mathrm{EE}_{2}$ concentra- tions below $1 \mathrm{ng} \mathrm{L}^{-1}$ caused a significant reduction in fertilization success, an increased egg production and decreased expression of secondary male sex characteristics [148]. Similar findings were obtained by Pawlowski et al. [149] in trials extended over a reduced period of three weeks. Concentrations below 1 $\mathrm{ng} \mathrm{L}^{-1}$ gave rise to an increased female population and for $\mathrm{EE}_{2}$ concentrations above

$3.5 \mathrm{ng} \mathrm{L}^{-1}$, fish became completely feminized [148]. Concentrations above $1 \mathrm{ng} \mathrm{L}^{-1}$ of $\mathrm{EE}_{2}$ also induced higher vitellogenin plasma lev- els in both males and females $[149,150]$. Nash et al. [151] registered similar findings for zebrafish males by simply performing the assay with $0.5 \mathrm{ng}$ $\mathrm{L}^{-1}$ of $\mathrm{EE}_{2}$. Life-long exposure of zebrafish to $5 \mathrm{ng} \mathrm{L}^{-1}$ of $\mathrm{EE}_{2}$ has led to reproductive failure due to the absence of sec- ondary male sex characteristics and normal testes [151]. Exposure of juveniles to estrogen has caused skewed sex ratios in favour of females for concentrations of $1 \mathrm{ng} \mathrm{L}^{-1}$ [150]. Sex reversal was complete at levels of $2 \mathrm{ng} \mathrm{L}^{-1}$ [150]. Xu et al. [152] also exposed zebrafish to $\mathrm{EE}_{2}$ during their period of sex differentiation, show- ing that, after 90 days posthatch, there was already an increase in mortality rate and sex ratio for fish exposed to concentrations of $2 \mathrm{ng} \mathrm{L}^{-1}$. When the concentration was increased to $10 \mathrm{ng} \mathrm{L}^{-1}$ was observed a significantly decrease in the weight and length body. On the other hand, 180 days post-hatch were found abnor- mal testicular morphologies in male fish, namely malformations of the sperm duct, an altered proportion of germ cell types, and a reduced number of spermatozoa, for those levels of $\mathrm{EE}_{2}$ [152]. Exposure of male roach to $\mathrm{EE}_{2}$ concentrations up to $4 \mathrm{ng} \mathrm{L}^{-1}$ in early life disrupted normal sexual development causing a femi- nized response, characterized by the presence of an ovarian cavity and induced plasma vitellogenin production [153]. Kidd et al. [34] conducted a 7year, whole-lake experiment, proving that chronic exposure of fathead minnow to concentrations of $\mathrm{EE}_{2}$ in the order of $5-6 \mathrm{ng} \mathrm{L}^{-1}$, led to feminization of males fish, through produc- tion of vitellogenin and disruption in gonadal development, causing intersex, and altered oogenesis in females. Those reproductive alterations led to a collapse of the fathead minnow population due to the loss of the young generations, expressed in a loss of smaller sizes classes of fish, what contribute, in a last case, to leave this species from the lake near of extinction [34]. The natural estrogen 17 -estradiol $\left(E_{2}\right)$ can also negatively affect fish at low concentra- tions. Japanese medaka exposed to $33.5 \mathrm{ng} \mathrm{L}^{-1}$ of this estrogen in early life enhanced their body length and body weight. Addition- ally, the males also exhibited testis-ova after 14 days of exposure [154]. When the $\mathrm{E}_{2}$ concentration was increased to $140.6 \mathrm{ng}$ $\mathrm{L}^{-1}$, testis-ova were observed in males (after 12 days exposure) and complete gonadal transformation to an ovary occurred after 20 days [154]. The exposure of adult fish to concentrations from 29.3 to $463 \mathrm{ng}$ $\mathrm{L}^{-1}$ over 21 days gave rise to testis-ova development and induced vitellogenin production in males to all tested con- centrations [155]. At the higher level, a decrease in the number of eggs produced and fertility [155] was also observed. Amphib- ians and reptiles exposed to environmental estrogens showed sex reversal as well as significant changes in secondary sex character- istics [156,157]. Concerning invertebrates such as the amphipod Hyalella azteca it was observed that at sub-lethal concentrations of $\mathrm{EE}_{2}\left(0.1-10 \mu \mathrm{g} \mathrm{L}^{-1}\right)$ sexual development of males was affected 
Table 4

\begin{tabular}{|c|c|c|c|c|c|c|c|c|c|c|c|c|}
\hline Compound & CAS number & Sample & Country & $\begin{array}{l}\text { Analytical } \\
\text { procedure }\end{array}$ & $\operatorname{LOD}\left(\mathrm{ngL}^{-1}\right)$ & $\begin{array}{l}\text { Concentration } \\
\text { reported }\left(\mathrm{ngL}^{-1}\right)\end{array}$ & Ref. & Taxon & Species & $\begin{array}{l}\text { Toxicological } \\
\text { endpoint }\end{array}$ & $\begin{array}{l}\text { Ecotoxicity } \\
\text { data }\end{array}$ & Ref. \\
\hline Diethylstilbestrol & 8053-00-7 & River water & China & SPME-GC-MS & 2 & $20( \pm 0)$ & [162] & & & & & \\
\hline $\begin{array}{l}\text { 17a-Estradiol } \\
17 a \text {-Estradiol }\end{array}$ & $57-91-0$ & $\begin{array}{l}\text { Surface water } \\
\text { Groundwater }\end{array}$ & $\begin{array}{l}\text { USA } \\
\text { France }\end{array}$ & $\begin{array}{l}\text { LLE-GC-MS } \\
\text { SPE-LC-MS/MS }\end{array}$ & $\begin{array}{l}5 \\
0.03\end{array}$ & $\begin{array}{l}30 \\
0.8-3.5\end{array}$ & $\begin{array}{l}{[23]} \\
{[164]}\end{array}$ & & & & & \\
\hline 17 Estradiol & $50-28-2$ & Surface water & USA & LLE-GC-MS & 5 & 9 & [23] & Fish & O. latipes & $\begin{array}{l}\text { NOEC }(21 \mathrm{~d}) \\
\text { (testis-ova induction) }\end{array}$ & $<29.3 \mathrm{ngL}^{-1}$ & {$[15] 5$} \\
\hline 17 Estradiol & & $\begin{array}{l}\text { Drinking } \\
\text { water }\end{array}$ & USA & SPE-LC-MS/MS & 0.50 & $<0.50$ & [32] & & & $\begin{array}{l}\text { LOEC ( } 21 \mathrm{~d} \text { ) } \\
\text { (testis-ova induction) }\end{array}$ & $<26.3 \mathrm{ngL}^{-1}$ & [155] \\
\hline \multirow[t]{2}{*}{17 Estradiol } & & $\begin{array}{l}\text { Hospital } \\
\text { effluent }\end{array}$ & Taiwan & $\begin{array}{l}\text { SPE- } \\
\text { HPLC-MS/MS }\end{array}$ & 25 & 25 & [47] & & & $\begin{array}{l}\text { NOEC (21 d) (VTG } \\
\text { induction) }\end{array}$ & $29.3 \mathrm{ngL}^{-1}$ & [155] \\
\hline & & $\begin{array}{l}\text { Pharmaceutical } \\
\text { production } \\
\text { facility } \\
\text { effluent }\end{array}$ & & & & ND & & & & & & \\
\hline 17 EStradiol & & $\begin{array}{l}\text { STP influent } \\
\text { STP effluent }\end{array}$ & Japan & SPE-GC-MS & 0.1 (LOQ) & $\begin{array}{l}13.3-25.8 \\
0.49-12.4\end{array}$ & [86] & & & & & \\
\hline 17 Estradiol & & $\begin{array}{l}\text { Pearl Rivers } \\
\text { water }\end{array}$ & China & SPE-GC-MS & 0.3 & $\mathrm{ND}-7.5( \pm 0.4)$ & [88] & & & & & \\
\hline \multirow{4}{*}{17 Estradiol } & & STP influent & Luxembourg & SPE-LC-MS/MS & 1.0 & $1.0-102$ & [89] & & & & & \\
\hline & & STPeffluent & & & & $1.0-85$ & & & & & & \\
\hline & & $\begin{array}{l}\text { Alzette river } \\
\text { water }\end{array}$ & & & & $1.0-35$ & & & & & & \\
\hline & & $\begin{array}{l}\text { Mess river } \\
\text { water }\end{array}$ & & & & $1.0-6$ & & & & & & \\
\hline \multirow[t]{2}{*}{ 17. Estradiol } & & STPeffluent & South Korea & SPE-LC-MS/MS & 1.0 & $<1.0$ & [90] & & & & & \\
\hline & & Surface water & & & & $\mathrm{ND}$ & & & & & & \\
\hline \multirow[t]{5}{*}{17 Estradiol } & & STP effluent & Japan & SPE-LC-MS/MS & 0.3 & $0.3-2.5$ & [160] & & & & & \\
\hline & & $\begin{array}{l}\text { Tamagawa } \\
\text { river water }\end{array}$ & & & & $0.6-1.0$ & & & & & & \\
\hline & & Kasumigaura & & & & & & & & & & \\
\hline & & lake water & & & & & & & & & & \\
\hline & & & & & & $<0.3$ & & & & & & \\
\hline \multirow[t]{3}{*}{ 17. Estradiol } & & STP influent & Germany & SPE-LC-MS/MS & 2.0 (LOQ STP influent) & $11.8( \pm 5.1)$ & [161] & & & & & \\
\hline & & STP effluent & & & 0.4 (LOQ STP effluent) & $0.8( \pm 0.3)$ & & & & & & \\
\hline & & $\begin{array}{l}\text { Berlin surface } \\
\text { water }\end{array}$ & & & 0.2 (LOQ surface water) & $<0.2$ & & & & & & \\
\hline 17. Estradiol & & River water & China & SPME-GC-MS & 9 & $100( \pm 20)$ & [162] & & & & & \\
\hline \multirow[t]{3}{*}{17 Estradiol } & & STP influent & Italy & SPE-LC-MS/MS & 1.9 (STP influent) & $10-31$ & [163] & & & & & \\
\hline & & STPeffluent & & & 0.8 (STP effluent) & $3-8$ & & & & & & \\
\hline & & $\begin{array}{l}\text { Tibre river } \\
\text { water }\end{array}$ & & & 0.2 (Tibre river water) & $2-6$ & & & & & & \\
\hline 17. Estradiol & & Groundwater & France & SPE-LC-MS/MS & 0.01 & $0.3-1.3$ & [164] & & & & & \\
\hline Estriol & $50-27-1$ & Surface water & USA & LLE-GC-MS & 5 & 19 & [23] & & & & & \\
\hline \multirow[t]{2}{*}{ Estriol } & & STP influent & Japan & SPE-GC-MS & $0.2(\mathrm{LOQ})$ & $83.0-255$ & [86] & & & & & \\
\hline & & STPeffluent & & & & $0.31-0.84$ & & & & & & \\
\hline \multirow[t]{2}{*}{ Estriol } & & STPeffluent & South Korea & SPE-LC-MS/MS & 5.0 & $8.9-25$ & [90] & & & & & \\
\hline & & Surface water & & & & ND & & & & & & \\
\hline \multirow[t]{3}{*}{ Estriol } & & STP influent & Italy & SPE-LC-MS/MS & 7.0 (STP influent) & $23-48$ & [163] & & & & & \\
\hline & & STPeffluent & & & 0.5 (STP effluent) & ND-1 & & & & & & \\
\hline & & $\begin{array}{l}\text { Tibre river } \\
\text { water }\end{array}$ & & & 0.3 (Tibre river water) & $2-5$ & & & & & & \\
\hline Estrone & 53-16-7 & Surface water & USA & LLE-GC-MS & 5 & 27 & [23] & & & & & \\
\hline Estrone & & $\begin{array}{l}\text { Drinking } \\
\text { water }\end{array}$ & USA & SPE-LC-MS/MS & 0.20 & $<0.20$ & [32] & & & & & \\
\hline
\end{tabular}




\begin{tabular}{|c|c|c|c|c|c|c|c|c|c|c|c|c|}
\hline Estrone & & $\begin{array}{l}\text { Hospital effluent } \\
\text { Pharmaceutical } \\
\text { production } \\
\text { facility } \\
\text { effluent } \\
\text { STP influent }\end{array}$ & Taiwan & $\begin{array}{l}\text { SPE-HPLC- } \\
\text { MS/MS }\end{array}$ & 25 & $\begin{array}{l}126 \\
\mathrm{ND}\end{array}$ & [47] & & & & & \\
\hline \multirow{2}{*}{\multicolumn{2}{|c|}{ Estrone }} & & Japan & SPE-GC-MS & $0.6(\mathrm{LOQ})$ & $28.7-197$ & [86] & & & & & \\
\hline & & STPeffluent & & & & $2.80-110$ & & & & & & \\
\hline Estrone & & $\begin{array}{l}\text { Pearl Rivers } \\
\text { water }\end{array}$ & China & SPE-GC-MS & 0.2 & ND-75.0 $( \pm 5.3)$ & [88] & & & & & \\
\hline \multirow{4}{*}{\multicolumn{2}{|c|}{ Estrone }} & STP influent & Luxembourg & SPE-LC-MS/MS & 0.3 & $0.3-9$ & [89] & & & & & \\
\hline & & STPeffluent & & & & $0.3-14$ & & & & & & \\
\hline & & $\begin{array}{l}\text { Alzette river } \\
\text { water }\end{array}$ & & & & $0.3-6$ & & & & & & \\
\hline & & $\begin{array}{l}\text { Mess river } \\
\text { water }\end{array}$ & & & & $0.3-27$ & & & & & & \\
\hline \multirow{2}{*}{\multicolumn{2}{|c|}{ Estrone }} & STP effluent & South Korea & SPE-LC-MS/MS & 1.0 & $2.2-36$ & [90] & & & & & \\
\hline & & Surface water & & & & $1.7-5.0$ & & & & & & \\
\hline \multirow{5}{*}{\multicolumn{2}{|c|}{ Estrone }} & STPeffluent & Japan & SPE-LC-MS/MS & 0.1 & $2.5-34$ & [160] & & & & & \\
\hline & & $\begin{array}{l}\text { Tamagawa } \\
\text { river water }\end{array}$ & & & & $3.4-6.6$ & & & & & & \\
\hline & & Kasumigaura & & & & & & & & & & \\
\hline & & lake water & & & & & & & & & & \\
\hline & & & & & & $0.2-0.8$ & & & & & & \\
\hline \multirow{3}{*}{\multicolumn{2}{|c|}{ Estrone }} & STP influent & Germany & SPE-LC-MS/MS & 1.0 (LOQ STP influent) & $188( \pm 92)$ & [161] & & & & & \\
\hline & & STP effluent & & & 0.2 (LOQ STP effluent) & $12.6( \pm 7.0)$ & & & & & & \\
\hline & & $\begin{array}{l}\text { Berlin surface } \\
\text { water }\end{array}$ & & & 0.1 (LOQ surface water) & $0.16( \pm 0.05)$ & & & & & & \\
\hline Estrone & & River water & China & SPME-GC-MS & 18 & $180( \pm 20)$ & [162] & & & & & \\
\hline \multirow{3}{*}{\multicolumn{2}{|c|}{ Estrone }} & STP influent & Italy & SPE-LC-MS/MS & 1.2 (STP influent) & $15-60$ & [163] & & & & & \\
\hline & & STPeffluent & & & 0.8 (STP effluent) & $5-30$ & & & & & & \\
\hline & & $\begin{array}{l}\text { Tibre river } \\
\text { water }\end{array}$ & & & 0.1 (Tibre river water) & $5-12$ & & & & & & \\
\hline \multicolumn{2}{|l|}{ Estrone } & Surface water & France & SPE-LC-MS/MS & 0.02 & 0.3 & [164] & & & & & \\
\hline 17a-Ethinylestradiol & $57-63-6$ & $\begin{array}{l}\text { Groundwater } \\
\text { Surface water }\end{array}$ & USA & LLE-GC-MS & 5 & $\begin{array}{l}0.8-3.5 \\
73\end{array}$ & [23] & Fish & P. promelas & $\begin{array}{l}\text { LOEC (21 d) (plasma } \\
\text { VTG induction) }\end{array}$ & $1 \mathrm{ngL}^{-1}$ & [149] \\
\hline $17 a$-Ethinylestradiol & & $\begin{array}{l}\text { Drinking } \\
\text { water }\end{array}$ & USA & SPE-LC-MS/MS & 1.0 & $<1.0$ & [32] & & & $\begin{array}{l}\text { LOEC }(21 \mathrm{~d}) \\
\text { (ultrastructure testes) }\end{array}$ & $1 \mathrm{ngL}^{-1}$ & [149] \\
\hline \multirow[t]{2}{*}{ 17a-Ethinylestradiol } & & $\begin{array}{l}\text { Hospital } \\
\text { effluent }\end{array}$ & Taiwan & $\begin{array}{l}\text { SPE- } \\
\text { HPLC-MS/MS }\end{array}$ & 25 & 32 & [47] & & & $\begin{array}{l}\text { LOEC }(21 \mathrm{~d}) \\
\text { (ultrastructure liver) }\end{array}$ & $1 \mathrm{ngL}^{-1}$ & [149] \\
\hline & & $\begin{array}{l}\text { Pharmaceutical } \\
\text { production } \\
\text { facility } \\
\text { effluent }\end{array}$ & & & & ND & & & & & & \\
\hline \multirow[t]{4}{*}{ 17a-Ethinylestradiol } & & STP influent & Luxembourg & SPE-LC-MS/MS & 2.0 & $2.0-24$ & [89] & & & $\begin{array}{l}\text { LOEC }(21 \mathrm{~d}) \\
\text { (fertilization rate) }\end{array}$ & $10 \mathrm{ng} \mathrm{L}^{-1}$ & [149] \\
\hline & & STPeffluent & & & & $<2.0$ & & & & & & \\
\hline & & $\begin{array}{l}\text { Alzette river } \\
\text { water }\end{array}$ & & & & $<2.0$ & & & & & & \\
\hline & & $\begin{array}{l}\text { Mess river } \\
\text { water }\end{array}$ & & & & $<2.0$ & & & & & & \\
\hline 17a-Ethinylestradiol & & STP effluent & South Korea & SPE-LC-MS/MS & 1.0 & 1.3 & [90] & Fish & D. rerio & $\begin{array}{l}\text { LOEC (38 dph) } \\
\text { (plasma VTG } \\
\text { induction) }\end{array}$ & $2 \mathrm{ngL}^{-1}$ & [150] \\
\hline
\end{tabular}




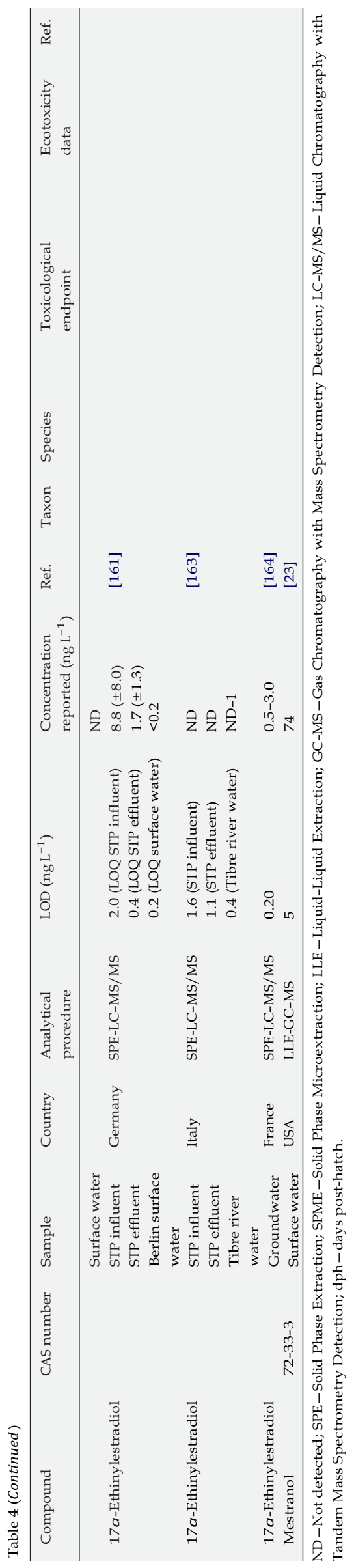

[158]. On the other hand, the estrogens $\mathrm{E}_{2}$ and $\mathrm{EE}_{2}$ did not show significant effects on reproduction or survival of $C$. dubia even at concentrations of 1 and $0.5 \mathrm{mg} \mathrm{L}^{-1}$, respectively [159]. According to many authors, the concentrations of estrogens detected in the environment may not post a threat to humans. However regard- ing these compounds, there is the possibility of bioaccumulation within aquatic organisms, thereby reaching humans through the food chain or directly through drinking water [146]. Estrogens have been found in water samples (Table 4) at low $\mathrm{ng} \mathrm{L}^{-1}$ concentra- tions but they represent a greater risk for non-target organisms as already proved. For example, 17-estradiol was detected in rivers [23,160-163] at levels ranging from 0.6 to $100 \mathrm{ng} \mathrm{L}^{-1}$ and in STP effluents at concentrations between 0.3 [160] and $85 \mathrm{ng} \mathrm{L}^{-1}$ [89]. Ethinylestradiol was also found in surface waters in the US (73 $\left.\mathrm{ng} \mathrm{L}^{-1}\right)$ [23] and Italy (the Tibre river) at $1 \mathrm{ng} \mathrm{L}^{-1}[163]$.

\subsection{Antiepileptics}

Antiepileptic drugs act in the central nervous system (CNS) by reducing the overall neuronal activity. This can be achieved either by blocking voltage-dependent sodium channels (e.g. car- bamazepine) or by enhancement of the inhibitory effects of the )'-aminobutyric acid (GABA) neurotransmitter (e.g. benzodi- azepines) [99]. Carbamazepine is carcinogenic to rats but does not have mutagenic properties in mammals [165]. Moreover, this drug is lethal to zebrafish at the $43 \mu \mathrm{g} \mathrm{L}^{-1}$ level and produces sub-lethal changes in Daphnia sp. at $92 \mu \mathrm{g} \mathrm{L}^{-1}$ [165]. Regarding aquatic organisms, it can be deduced that carbamazepine does have harmful proclivity since most of the acute toxicity data were har- vested from trial concentrations between 10 and $100 \mathrm{mg} \mathrm{L}^{-1}$ [98]. In fact, D. magna growth was shown to be sensitive to this com- pound, being inhibited for concentrations of carbamazepine above

$12.7 \mathrm{mg} \mathrm{L}^{-1}$ and with acute toxicity being evident at $17.2 \mathrm{mg} \mathrm{L}^{-1}$ [165]. The $\mathrm{EC}_{50}$ value (considering the motility as indicator) was approximately $13.8 \mathrm{mg} \mathrm{L}^{-1}$ after $48 \mathrm{~h}$ of exposure [96]. Female $D$. pulex exposed to $1 \mu \mathrm{g} \mathrm{L}^{-1}$ of carbamazepine showed a tendency to mature and reproduce earlier (with more offspring), suggesting that this pharmaceutical may slightly induce stimulatory effects [166]. For $C$. dubia, chronic toxicity studies revealed a NOEC of $25 \mu \mathrm{g} \mathrm{L}^{-1}$ [96] while the activity of $G$. pulex was slightly reduced by exposure to a concentration range from 1 to $10 \mathrm{ng} \mathrm{L}^{-1}$ [76]. Continuous exposure of $H$. attenuata to carbamazepine caused a significant reduction in feeding, with an $\mathrm{EC}_{50}$ of $3.76 \mathrm{mg} \mathrm{L}^{-1}$ [98]. Japanese medaka showed a $\mathrm{LC}_{50}$ of $35.4 \mathrm{mg} \mathrm{L}^{-1}$ [82] and ultrastruc- tural changes in the liver, kidney and gill tissues of carps were induced by this pharmaceutical [97]. The changes observed in the kidney were shown to occur as a cellular response to impaired kidney function. In gills, the effects were more pronounced for con- centrations above $20 \mu \mathrm{g} \mathrm{L} \mathrm{L}^{-1}$. Another important issue concerning carbamazepine is that it can adsorb to sediments, in this way threat- ening aquatic organisms which feed on organic matter. Oetken et al. [167] showed that exposure of the invertebrate Chironomus ripar-ius to this pharmaceutical through sediments caused a blockade of pupation and decreased emergence with $\mathrm{EC}_{50}$ values of 160 and $280 \mu \mathrm{g} \mathrm{kg}^{-1}$ of dry weight, respectively. Carbamazepine is ubiq- uitously present in the environment, having an extremely low removal rate in STPs (7\%) [54] and consequently being detected in rivers $[16,20,21,54,92]$ at concentrations up to 595 $\mathrm{ng} \mathrm{L}^{-1}$ [92] (Table 5). In addition to surface waters, carbamazepine has also been found in groundwater [26,119] at concentrations that can reach $900 \mathrm{ng} \mathrm{L}^{-1}$. A monitoring programme performed on the river Rhine (Germany) over a decade, showed the regular detection of carbamazepine, with an annual average concentration of $100 \mathrm{ng} \mathrm{L}^{-1}$ [168]. These results support the idea that the presence of carba- mazepine in the environment may represent a real threat. 
Table 5

Examples of concentrations $\left(\mathrm{ng} \mathrm{L}^{-1}\right)$ of antiepileptic drugs measured in different aquatic environments.

\begin{tabular}{|c|c|c|c|c|c|c|c|c|c|c|c|c|}
\hline Compound & CAS number & Sample & Country & $\begin{array}{l}\text { Analytical } \\
\text { procedure }\end{array}$ & $\operatorname{LOD}\left(\mathrm{ngL}^{-1}\right)$ & $\begin{array}{l}\text { Concentration } \\
\text { reported }\left(\mathrm{ngL}^{-1}\right)\end{array}$ & Ref. & Taxon & Species & $\begin{array}{l}\text { Toxicological } \\
\text { endpoint }\end{array}$ & $\begin{array}{l}\text { Ecotoxicity } \\
\text { data }\end{array}$ & Ref. \\
\hline Carbamazepine & $298-46-4$ & STP influent & Spain & SPE-GC-MS & 30 & $120-310$ & [14] & Crustacean & D. magna & $\begin{array}{l}\mathrm{EC}_{50}(48 \mathrm{~h}) \\
\text { (immobilization) }\end{array}$ & $>100 \mathrm{mgL}^{-1}$ & [65] \\
\hline \multirow[t]{4}{*}{ Carbamazepine } & & $\begin{array}{l}\text { STP effluent } \\
\text { STP influent }\end{array}$ & Finland & $\begin{array}{l}\text { SPE- } \\
\text { HPLC-MS/MS }\end{array}$ & 1.4 & $\begin{array}{l}110-230 \\
290-400\end{array}$ & [16] & Algae & D. subspicatus & $\begin{array}{l}\mathrm{EC}_{50} \text { (growth } \\
\text { inhibition) }\end{array}$ & $74 \mathrm{mgL}^{-1}$ & [65] \\
\hline & & STP effluent & & & & $380-470$ & & & & & & \\
\hline & & $\begin{array}{l}\text { Vantaa river } \\
\text { water }\end{array}$ & & & & $<1.4-66$ & & & & & & \\
\hline & & $\begin{array}{l}\text { Luhtajoki } \\
\text { river water }\end{array}$ & & & & 23 & & & & & & \\
\hline Carbamazepine & & $\begin{array}{l}\text { Somes river } \\
\text { water }\end{array}$ & Romania & SPE-GC-MS & 30 & $<30-75.1( \pm 6.1)$ & [20] & Duckweed & L. minor & $\begin{array}{l}\mathrm{EC}_{50}(7 \mathrm{~d}) \text { (growth } \\
\text { inhibition) }\end{array}$ & $25.5 \mathrm{mgL}^{-1}$ & [65] \\
\hline \multirow[t]{3}{*}{ Carbamazepine } & & STP influent & Sweden & SPE-LC-MS/MS & $-\dagger$ & 1680 & [21] & Crustacean & $\begin{array}{l}\text { Gammarus } \\
\text { pulex }\end{array}$ & LOEC (behaviour) & $10 \mathrm{ngL}^{-1}$ & [76] \\
\hline & & STP effluent & & & & 1180 & & & & & & \\
\hline & & $\begin{array}{l}\text { Höje river } \\
\text { water }\end{array}$ & & & & $<1-500$ & & & & & & \\
\hline Carbamazepine & & Groundwater & Germany & SPE-GC-MS & 32 & 900 & [26] & Crustacean & T. platyurus & $\mathrm{LC}_{50}(24 \mathrm{~h})$ (mortality) & $>100 \mathrm{mgL}^{-1}$ & [78] \\
\hline Carbamazepine & & $\begin{array}{l}\text { Drinking } \\
\text { water }\end{array}$ & USA & SPE-LC-MS/MS & 0.5 & 6.8 & [32] & Fish & o. latipes & $\mathrm{LC}_{50}(96 \mathrm{~h})$ (mortality) & $45.87 \mathrm{mg} \mathrm{L}^{-1}$ & [78] \\
\hline Carbamazepine & & STP effluent & Germany & SPE-LC-MS/MS & 50 (STP effluent) & 2100 & [54] & Bacteria & V. fischeri & $\mathrm{EC}_{50}(15 \mathrm{~min})$ & $52.2 \mathrm{mg} \mathrm{L}^{-1}$ & [82] \\
\hline Carbamazepine & & $\begin{array}{l}\text { Surface water } \\
\text { Hospital } \\
\text { effluent }\end{array}$ & Spain & $\begin{array}{l}\text { SPE- } \\
\text { HPLC-MS/MS }\end{array}$ & $\begin{array}{l}30 \text { (surface water) } \\
7\end{array}$ & $\begin{array}{l}250 \\
30-70\end{array}$ & [73] & Crustacean & D. magna & $\begin{array}{l}\mathrm{EC}_{50}(48 \mathrm{~h}) \\
\text { (immobilization) }\end{array}$ & $>100 \mathrm{mgL}^{-1}$ & [82] \\
\hline \multirow[t]{5}{*}{ Carbamazepine } & & $\begin{array}{l}\text { Danube river } \\
\text { water }\end{array}$ & Serbia & SPE-LC-MS/MS & 0.27 & $8-130$ & [84] & & D. magna & $\begin{array}{l}\mathrm{EC}_{50}(96 \mathrm{~h}) \\
\text { (immobilization) }\end{array}$ & $76.3 \mathrm{mg} \mathrm{L}^{-1}$ & [82] \\
\hline & & $\begin{array}{l}\text { Sava river } \\
\text { water }\end{array}$ & & & & $29-50$ & & & & & & \\
\hline & & $\begin{array}{l}\text { Tamis` river } \\
\text { water }\end{array}$ & & & & 30 & & & & & & \\
\hline & & $\begin{array}{l}\text { Lake Očaga } \\
\text { water }\end{array}$ & & & & 30 & & & & & & \\
\hline & & Groundwater & & & & $6-23$ & & & & & & \\
\hline Carbamazepine & & STP influent & Japan & SPE-GC-MS & 6 & $14.9-270$ & [86] & Fish & O. latipes & $\mathrm{LC}_{50}(48 \mathrm{~h})$ & $35.4 \mathrm{mg} \mathrm{L}^{-1}$ & [82] \\
\hline \multirow[t]{2}{*}{ Carbamazepine } & & $\begin{array}{l}\text { STP effluent } \\
\text { STP influent }\end{array}$ & Taiwan & $\begin{array}{l}\text { SPE-HPLC- } \\
\text { MS/MS }\end{array}$ & -+ & $\begin{array}{l}10.8-163 \\
82-357\end{array}$ & [87] & & O. latipes & $\mathrm{LC}_{50}(96 \mathrm{~h})$ & $35.4 \mathrm{mg} \mathrm{L}^{-1}$ & [82] \\
\hline & & STP effluent & & & & $93-214$ & & & & & & \\
\hline \multirow[t]{2}{*}{ Carbamazepine } & & STP effluent & South Korea & SPE-LC-MS/MS & 1.0 & $73-729$ & [90] & Bacteria & V. fischeri & $\mathrm{EC}_{50}(30 \mathrm{~min})$ & $>81,000 \mu \mathrm{gL}^{-1}$ & [96] \\
\hline & & $\begin{array}{l}\text { Surface water } \\
\text { Drinking } \\
\text { water }\end{array}$ & & & & $\begin{array}{l}4.5-61 \\
<1.0\end{array}$ & & & & & & \\
\hline Carbamazepine & & $\begin{array}{l}\text { Mankyung } \\
\text { river water }\end{array}$ & South Korea & SPE-LC-MS/MS & 1 & ND-595 ( \pm 14$)$ & [92] & Algae & P. subcapitata & $\begin{array}{l}\text { NOEC(96h)(growth } \\
\text { inhibition) }\end{array}$ & $>100,000 \mu \mathrm{gL}^{-1}$ & [96] \\
\hline \multirow[t]{3}{*}{ Carbamazepine } & & STP influent & Korea & SPE-LC-MS & 5 & $<5-451$ & [93] & & & $\begin{array}{l}\text { LOEC(96h)(growth } \\
\text { inhibition) }\end{array}$ & $>100,000 \mu \mathrm{gL}^{-1}$ & [96] \\
\hline & & STP effluent & & & & $<5-195$ & & & & & & \\
\hline & & $\begin{array}{l}\text { Han river } \\
\text { water }\end{array}$ & & & & $<5-36$ & & & & & & \\
\hline Carbamazepine & & STP effluent & Italy & $\begin{array}{l}\text { SPE- } \\
\text { HPLC-MS/MS }\end{array}$ & 1.3 & ND-1318 & {$[118]$} & Crustacean & D. magna & $\begin{array}{l}\mathrm{EC}_{50}(48 \mathrm{~h}) \\
\text { (immobilization) }\end{array}$ & $>13,800 \mu \mathrm{gL}^{-1}$ & [96] \\
\hline Carbamazepine & & Groundwater & Germany & SPE-GC-MS & $2(\mathrm{LOQ})$ & 45 & [119] & & C. dubia & $\begin{array}{l}\mathrm{EC}_{50}(48 \mathrm{~h}) \\
\text { (immobilization) }\end{array}$ & $77,700 \mu \mathrm{g} \mathrm{L}^{-1}$ & [96] \\
\hline \multirow[t]{2}{*}{ Carbamazepine } & & STP influent & France & SPE-LC-MS & 2.4 & $193-420$ & [169] & & & $\begin{array}{l}\text { NOEC (7d) } \\
\text { NOmonilion) }\end{array}$ & $25 \mu \mathrm{gL}^{-1}$ & [96] \\
\hline & & STP effluent & & & & $86-258$ & & & & (reproduction) & & \\
\hline
\end{tabular}




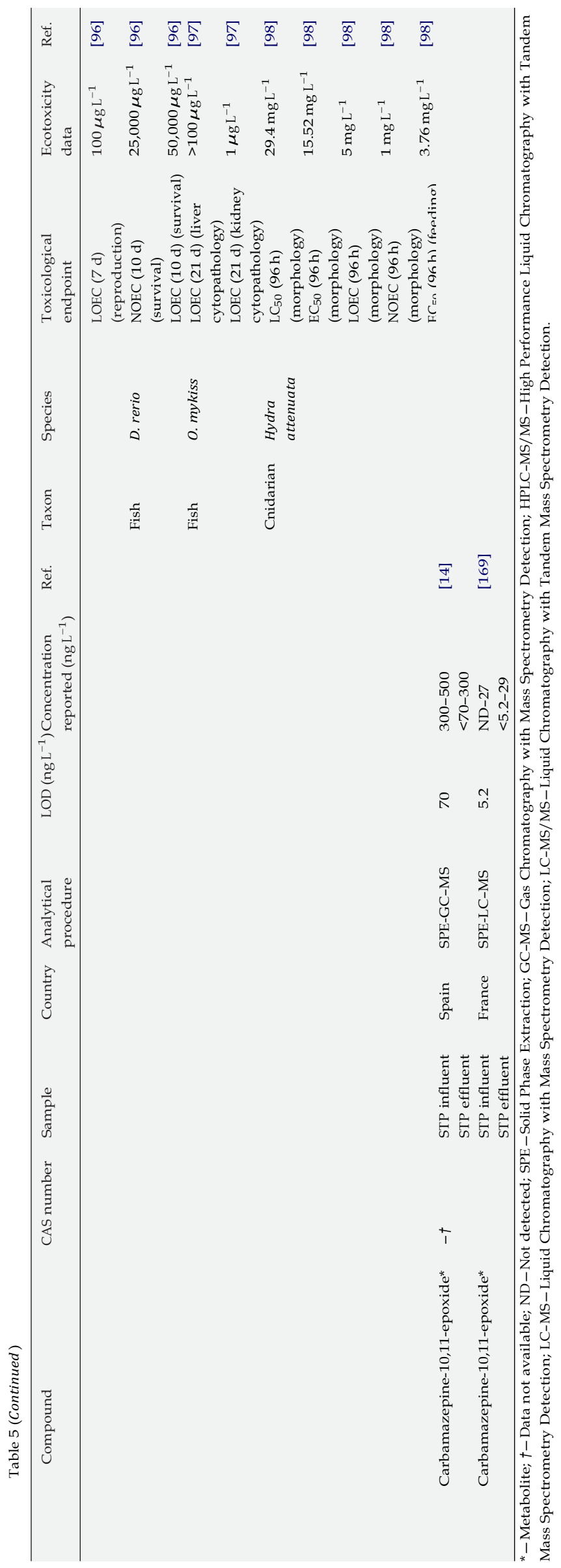

\subsection{Beta-blockers}

Beta-blockers act by competitive inhibition of beta-adrenergic receptors, a class of receptors critical for normal functioning in the sympathetic branch of the vertebrate autonomic nervous sys- tem in vertebrates. Within the most commonly used -blockers propranolol is a non-specific antagonist, blocking both $>_{1}$ and

${ }_{2}$-receptors while metoprolol and atenolol present 1 -receptors specificity [99]. Fish, like other vertebrates, possess -receptors in the heart, liver and reproductive system $[170,171]$ so that pro- longed exposure to drugs belonging to this therapeutic class may cause deleterious effects. From a two weeks study, it was observed that exposure to $500 \mu \mathrm{g} \mathrm{L}^{-1}$ of propranolol reduced growth rates of Japanese medaka [172]. Plasma steroid levels were altered in both male and female fish even at concentrations as low as $1 \mu \mathrm{g} \mathrm{L}^{-1}$ pro- pranolol. Exposure to concentrations of 0.5 and $1 \mu \mathrm{g} \mathrm{L}^{-1}$ resulted

in a decreased egg production. On the other hand, acute expo- sure of rainbow trout to $70.9 \mu \mathrm{g} \mathrm{L}^{-1}$ of propranolol showed no significant reduction in its heart rate [173]. However, for con- centrations of metoprolol of $1 \mu \mathrm{g} \mathrm{L}^{-1}$, ultrastructural changes in the liver and kidney were observed as well in gills if the con- centration rose above $20 \mu \mathrm{g} \mathrm{L}^{-1}$ [97]. Fathead minnows exposed to atenolol during embryo-larval development showed NOEC and LOEC values for growth rate of 3.2 and $10 \mathrm{mg} \mathrm{L}^{-1}$, respectively [174]. Furthermore, a reproduction study performed in adults over a 21 - day exposure period demonstrated that the male fish condition index was the most sensitive endpoint with NOEC and LOEC val- ues of 1.0 and $3.2 \mathrm{mg} \mathrm{L}^{-1}$, respectively [174]. These data suggest that atenolol has a low chronic toxicity to fish when compared to propranolol.

As invertebrates do not possess -receptors a different poten- tial impact on these organisms would be expected. Accordingly, the acute toxicity of propranolol, metoprolol and nadolol was assessed on the invertebrates $H$. azteca, D. magna, D. lumholtzi and C. dubia. Following a 48-h exposure to propranolol, $\mathrm{LC}_{50}$ values of 29.8 , 1.6 and $0.8 \mathrm{mg} \mathrm{L}^{-1}$ were obtained for H. azteca, D. magna and C. dubia respectively [172] while acute exposure to nadolol did not affect the survival of the invertebrates [172]. Regarding meto- prolol, $D$. magna and $C$. dubia exhibited $\mathrm{LC}_{50}$ values of 63.9 and $8.8 \mathrm{mg} \mathrm{L}^{-1}$, respectively [172]. However, Cleuvers [175] obtained a higher $\mathrm{EC}_{50}$ value $\left(438 \mathrm{mg} \mathrm{L}^{-1}\right)$ in an acute toxicity test performed on $D$. magna. Reproduction in invertebrates decreased following propranolol exposure with NOEC values of 1 and $125 \mu \mathrm{g} \mathrm{L}^{-1}$ for

H. azteca and C. dubia respectively [172]. Propranolol inhibited the growth of the green algae Desmodesmus subspicatus, showing an $\mathrm{EC}_{50}$ of $7.7 \mathrm{mg} \mathrm{L}^{-1}$ [175] while atenolol almost failed to reg-ister a toxic effect $\left(\mathrm{EC}_{50}\right.$ of $\left.620 \mathrm{mg} \mathrm{L}{ }^{-1}\right)$. Chronic exposure of D. magna to propranolol (9 days) resulted in a significant reduction in heart rate, fecundity and biomass with LOECs values of 55, 110 and $440 \mu \mathrm{g} \mathrm{L}^{-1}$ respectively [176] while chronic exposure to meto- prolol showed LOECs of $12.5 \mathrm{mg} \mathrm{L}^{-1}$ (body mass) and $6.15 \mathrm{mg} \mathrm{L}^{-1}$ (reproduction). At the highest concentrations ( 25 and $50 \mathrm{mg} \mathrm{L}^{-1}$ ) reproduction ceased and at the highest levels, all organisms died before the end of the test. A reduced heart rate for D. magna was evident for a $3.2 \mathrm{mg} \mathrm{L}^{-1}$ level of metoprolol. Chronic toxicity tests performed in algae also evidenced their sensitivity to blockers with NOEC values below $1 \mathrm{mgL}^{-1}$ [52].

Collectively, this data might indicate a possible environmental risk since propranolol has been detected in STP effluents [21,53,94] at concentrations from 30 to $373 \mathrm{ng} \mathrm{L}^{-1}$ and in surface waters $[21,53,92,94]$ at levels of $\mathrm{ng} \mathrm{L}^{-1}$ (Table 6). This pharmaceutical has also been found in hospital effluent (Spain) at concentrations that can reach $6.5 \mu \mathrm{g} \mathrm{L}^{-1}$ [73]. Other -blockers such as atenolol, metoprolol and solatol have also been detected in environmental samples $[16,21,24,73,118]$ including groundwater [26] at concen- trations up to $122 \mu \mathrm{gL}^{-1}$. 
Table 6

\begin{tabular}{|c|c|c|c|c|c|c|c|c|c|c|c|c|}
\hline Compound & CAS number & Sample & Country & $\begin{array}{l}\text { Analytical } \\
\text { procedure }\end{array}$ & $\operatorname{LOD}\left(\mathrm{ngL}^{-1}\right)$ & $\begin{array}{l}\text { Concentration } \\
\text { reported }\left(\mathrm{ngL}^{-1}\right)\end{array}$ & Ref. & Taxon & Species & $\begin{array}{l}\text { Toxicological } \\
\text { endpoint }\end{array}$ & $\begin{array}{l}\text { Ecotoxicity } \\
\text { data }\end{array}$ & Ref. \\
\hline \multirow[t]{4}{*}{ Acebutolol } & $37517-30-9$ & STP influent & Finland & $\begin{array}{l}\text { SPE- } \\
\text { HPLC-MS/MS }\end{array}$ & 0.8 & $390-510$ & [16] & & & & & \\
\hline & & STP effluent & & & & $80-230$ & & & & & & \\
\hline & & $\begin{array}{l}\text { Vantaa river } \\
\text { water }\end{array}$ & & & & $<0.8-8$ & & & & & & \\
\hline & & $\begin{array}{l}\text { Luhtajoki } \\
\text { river water }\end{array}$ & & & & 8 & & & & & & \\
\hline \multirow[t]{4}{*}{ Atenolol } & 29122-68-7 & STP influent & Finland & $\begin{array}{l}\text { SPE- } \\
\text { HPLC-MS/MS }\end{array}$ & 11.8 & $510-800$ & [16] & Crustacean & T. platyurus & $\begin{array}{l}\mathrm{LC}_{50}(24 \mathrm{~h}) \\
\text { (mortality) }\end{array}$ & $>100 \mathrm{mg} \mathrm{L}^{-1}$ & [78] \\
\hline & & STPeffluent & & & & $40-440$ & & & & & & \\
\hline & & $\begin{array}{l}\text { Vantaa river } \\
\text { water }\end{array}$ & & & & $<11.8-25$ & & & & & & \\
\hline & & $\begin{array}{l}\text { Luhtajoki } \\
\text { river water }\end{array}$ & & & & $<11.8$ & & & & & & \\
\hline \multirow[t]{3}{*}{ Atenolol } & & STP influent & Sweden & SPE-LC-MS/MS & $-\dot{t}$ & 30 & [21] & Fish & O. latipes & $\begin{array}{l}\mathrm{LC}_{50}(96 \mathrm{~h}) \\
\text { (mortality) }\end{array}$ & $>100 \mathrm{mg} \mathrm{L}^{-1}$ & {$[78]$} \\
\hline & & STP effluent & & & & 160 & & & & & & \\
\hline & & $\begin{array}{l}\text { Höje river } \\
\text { water }\end{array}$ & & & & $10-60$ & & & & & & \\
\hline \multirow[t]{2}{*}{ Atenolol } & & $\begin{array}{l}\text { Po river } \\
\text { water }\end{array}$ & Italy & $\begin{array}{l}\text { SPE- } \\
\text { HPLC-MS/MS }\end{array}$ & 0.3 (LOQ) & $3.44-39.43$ & [24] & Algae & D. subspicatus & $\begin{array}{l}\mathrm{EC}_{50} \text { (growth } \\
\text { inhibition) }\end{array}$ & $620 \mathrm{mgL}^{-1}$ & {$[17] 5$} \\
\hline & & $\begin{array}{l}\text { Lambro river } \\
\text { water }\end{array}$ & & & & 241 & & & & & & \\
\hline Atenolol & & $\begin{array}{l}\text { Drinking } \\
\text { water }\end{array}$ & USA & SPE-LC-MS/MS & 0.25 & 0.47 & [32] & Crustacean & D. magna & $\begin{array}{l}\mathrm{EC}_{50}(48 \mathrm{~h}) \\
\text { (immobilization) }\end{array}$ & $313 \mathrm{mg} \mathrm{L}^{-1}$ & [175] \\
\hline Atenolol & & $\begin{array}{l}\text { Hospital } \\
\text { effluent }\end{array}$ & Spain & $\begin{array}{l}\text { SPE- } \\
\text { HPLC-MS/MS }\end{array}$ & 28 & $100-122,000$ & [73] & Fish & P. promelas & NOEC (28 d) (growth) & $3.2 \mathrm{mgL}^{-1}$ & [174] \\
\hline Atenolol & & $\begin{array}{l}\text { Mankyung } \\
\text { river water }\end{array}$ & South Korea & SPE-LC-MS/MS & 30 & ND-690 ( \pm 26$)$ & [92] & & & LOEC (28 d) (growth) & $10 \mathrm{mgL}^{-1}$ & [174] \\
\hline \multirow[t]{2}{*}{ Atenolol } & & STP influent & Taiwan & $\begin{array}{l}\text { SPE-HPLC- } \\
\text { MS/MS }\end{array}$ & $-\dot{t}$ & $738-2883$ & [87] & & & $\begin{array}{l}\text { NOEC ( } 21 \mathrm{~d} \text { ) } \\
\text { (condition index) }\end{array}$ & $1.0 \mathrm{mgL}^{-1}$ & [174] \\
\hline & & STPeffluent & & & & $210-681$ & & & & & & \\
\hline \multirow[t]{3}{*}{ Atenolol } & & STPeffluent & Italy & $\begin{array}{l}\text { SPE- } \\
\text { HPLC-MS/MS }\end{array}$ & $1.07(\mathrm{LOQ})$ & $27-1168$ & [118] & & & $\begin{array}{l}\text { LOEC }(21 \mathrm{~d} \text { ) } \\
\text { (condition index) }\end{array}$ & $3.2 \mathrm{mgL}^{-1}$ & [174] \\
\hline & & & & & & & & & & $\begin{array}{l}\text { NOEC }(21 \mathrm{~d}) \\
\text { (reproduction) }\end{array}$ & $10 \mathrm{mgL}^{-1}$ & [174] \\
\hline & & & & & & & & & & $\begin{array}{l}\operatorname{LOEC}(21 \mathrm{~d}) \\
\text { (reproduction) }\end{array}$ & $>10 \mathrm{mgL}^{-1}$ & [174] \\
\hline \multirow[t]{4}{*}{ Metoprolol } & $83-43-2$ & STP influent & Finland & $\begin{array}{l}\text { SPE- } \\
\text { HPLC-MS/MS }\end{array}$ & 3.8 & $980-1350$ & [16] & Crustacean & D. magna & $\begin{array}{l}\mathrm{EC}_{50}(48 \mathrm{~h}) \\
\text { (immobilization) }\end{array}$ & $>100 \mathrm{mg} \mathrm{L}^{-1}$ & [65] \\
\hline & & STPeffluent & & & & $910-1070$ & & & & & & \\
\hline & & $\begin{array}{l}\text { Vantaa river } \\
\text { water }\end{array}$ & & & & $<3.8-116$ & & & & & & \\
\hline & & $\begin{array}{l}\text { Luhtajoki } \\
\text { river water }\end{array}$ & & & & 38 & & & & & & \\
\hline \multirow[t]{3}{*}{ Metoprolol } & & STP influent & Sweden & SPE-LC-MS/MS & $-\dot{t}$ & 160 & [21] & Algae & D. subspicatus & $\begin{array}{l}\mathrm{EC}_{50} \text { (growth } \\
\text { inhibition) }\end{array}$ & $7.3 \mathrm{mgL}^{-1}$ & [65] \\
\hline & & STP effluent & & & & 190 & & & & & & \\
\hline & & $\begin{array}{l}\text { Höje river } \\
\text { water }\end{array}$ & & & & $30-70$ & & & & & & \\
\hline Metoprolol & & STP influent & Taiwan & $\begin{array}{l}\text { SPE-HPLC- } \\
\text { MS/MS }\end{array}$ & $-\dot{t}$ & $14-597$ & [87] & Duckweed & L. minor & $\begin{array}{l}\mathrm{EC}_{50}(7 \mathrm{~d}) \text { (growth } \\
\text { inhibition) }\end{array}$ & $>320 \mathrm{mg} \mathrm{L}^{-1}$ & [65] \\
\hline
\end{tabular}




\begin{tabular}{|c|c|c|c|c|c|c|c|c|c|c|c|c|}
\hline Compound & CAS number & Sample & Country & $\begin{array}{l}\text { Analytical } \\
\text { procedure }\end{array}$ & $\operatorname{LOD}\left(\mathrm{ngL}^{-1}\right)$ & $\begin{array}{l}\text { Concentration } \\
\text { reported }\left(\mathrm{ngL}^{-1}\right)\end{array}$ & Ref. & Taxon & Species & $\begin{array}{l}\text { Toxicological } \\
\text { endpoint }\end{array}$ & $\begin{array}{l}\text { Ecotoxicity } \\
\text { data }\end{array}$ & Ref. \\
\hline & & STPeffluent & & & & $12-199$ & & & & & & \\
\hline & & & & & & & & Fish & O. mykiss & $\begin{array}{l}\text { LOEC }(21 \mathrm{~d}) \text { (liver } \\
\text { cytopathology) }\end{array}$ & $1 \mu \mathrm{gL}^{-1}$ & [97] \\
\hline & & & & & & & & & & $\begin{array}{l}\text { LOEC ( } 21 \mathrm{~d})(\text { gills } \\
\text { cytopathology) }\end{array}$ & $20 \mu \mathrm{gL}^{-1}$ & [97] \\
\hline & & & & & & & & Crustacean & H. azteca & $\begin{array}{l}\mathrm{LC}_{50}(48 \mathrm{~h}) \\
\text { (mortality) }\end{array}$ & $>100 \mathrm{mg} \mathrm{L}^{-1}$ & [172] \\
\hline & & & & & & & & & C. dudia & $\begin{array}{l}\mathrm{LC}_{50}(48 \mathrm{~h}) \\
\text { (mortality) }\end{array}$ & $8.8 \mathrm{mgL}^{-1}$ & [172] \\
\hline & & & & & & & & & D. magna & $\begin{array}{l}\mathrm{LC}_{50}(48 \mathrm{~h}) \\
\text { (mortality) }\end{array}$ & $63.9 \mathrm{mgL}^{-1}$ & [172] \\
\hline & & & & & & & & Fish & O. latipes & $\begin{array}{l}\mathrm{LC}_{50}(48 \mathrm{~h}) \\
\text { (mortality) }\end{array}$ & $>100 \mathrm{mg} \mathrm{L}^{-1}$ & [172] \\
\hline & & & & & & & & Algae & D. subspicatus & $\begin{array}{l}\mathrm{EC}_{50}(48 \mathrm{~h}) \text { (growth } \\
\text { inhibition) }\end{array}$ & $7.9 \mathrm{mgL}^{-1}$ & [177] \\
\hline & & & & & & & & Crustacean & D. magna & $\begin{array}{l}\mathrm{EC}_{50}(48 \mathrm{~h}) \\
\text { (immobilization) }\end{array}$ & $438 \mathrm{mgL}^{-1}$ & [175] \\
\hline & & & & & & & & Crustacean & D. magna & $\begin{array}{l}\text { NOEC }(9 \mathrm{~d}) \text { (body } \\
\text { mass) }\end{array}$ & $6.15 \mathrm{mg} \mathrm{L}^{-1}$ & [176] \\
\hline & & & & & & & & & & $\begin{array}{l}\text { LOEC }(9 \mathrm{~d}) \text { (body } \\
\text { mass) }\end{array}$ & $12.5 \mathrm{mg} \mathrm{L}^{-1}$ & [176] \\
\hline & & & & & & & & & & $\begin{array}{l}\text { LOEC (9d) } \\
\text { (reproduction) }\end{array}$ & $6.15 \mathrm{mgL}^{-1}$ & [176] \\
\hline & & & & & & & & & & $\begin{array}{l}\operatorname{LOEC}(9 \mathrm{~d}) \text { (heart } \\
\text { rate) }\end{array}$ & $3.2 \mathrm{mgL}^{-1}$ & [176] \\
\hline \multirow[t]{3}{*}{ Propranolol } & $525-66-6$ & STP influent & Sweden & SPE-LC-MS/MS & $-\dagger$ & 50 & [21] & Crustacean & D. magna & $\begin{array}{l}\mathrm{EC}_{50}(48 \mathrm{~h}) \\
\text { (immobilization) }\end{array}$ & $7.5 \mathrm{mgL}^{-1}$ & [65] \\
\hline & & STPeffluent & & & & 30 & & & & & & \\
\hline & & $\begin{array}{l}\text { Höje river } \\
\text { water }\end{array}$ & & & & $<1-10$ & & & & & & \\
\hline \multirow[t]{2}{*}{ Propranolol } & & $\begin{array}{l}\text { Hospital } \\
\text { effluent }\end{array}$ & Taiwan & $\begin{array}{l}\text { SPE- } \\
\text { HPLC-MS/MS }\end{array}$ & 0.5 & 54 & [47] & Algae & D. subspicatus & $\begin{array}{l}\mathrm{EC}_{50} \text { (growth } \\
\text { inhibition) }\end{array}$ & $5.8 \mathrm{mgL}^{-1}$ & [65] \\
\hline & & $\begin{array}{l}\text { Pharmaceutical } \\
\text { production } \\
\text { facility } \\
\text { effluent }\end{array}$ & & & & ND & & & & & & \\
\hline \multirow[t]{3}{*}{ Propranolol } & & STP influent & United Kingdom & $\begin{array}{l}\text { SPE- } \\
\text { HPLC-MS/MS }\end{array}$ & 10 & $60-119$ & [53] & Duckweed & L. minor & $\begin{array}{l}\mathrm{EC}_{50}(7 \mathrm{~d}) \text { (growth } \\
\text { inhibition) }\end{array}$ & $114 \mathrm{mgL}^{-1}$ & [65] \\
\hline & & STPeffluent & & & & $195-373$ & & & & & & \\
\hline & & $\begin{array}{l}\text { Tyne river } \\
\text { water }\end{array}$ & & & & 35-107 & & & & & & \\
\hline Propranolol & & $\begin{array}{l}\text { Hospital } \\
\text { effluent }\end{array}$ & Spain & $\begin{array}{l}\text { SPE- } \\
\text { HPLC-MS/MS }\end{array}$ & 8 & $200-6500$ & [73] & Crustacean & T. platyurus & $\begin{array}{l}\mathrm{LC}_{50}(24 \mathrm{~h}) \\
\text { (mortality) }\end{array}$ & $10.31 \mathrm{mg} \mathrm{L}^{-1}$ & [78] \\
\hline Propranolol & & $\begin{array}{l}\text { Mankyung } \\
\text { river water }\end{array}$ & South Korea & SPE-LC-MS/MS & 10 & ND-40.1 ( \pm 3$)$ & [92] & Fish & O. latipes & $\begin{array}{l}\mathrm{LC}_{50}(96 \mathrm{~h}) \\
\text { (mortality) }\end{array}$ & $11.40 \mathrm{mg} \mathrm{L}^{-1}$ & [78] \\
\hline \multirow[t]{3}{*}{ Propranolol } & & STPeffluent & United Kingdom & $\begin{array}{l}\text { SPE- } \\
\text { HPLC-MS/MS }\end{array}$ & & $130-180$ & [94] & Crustacean & H. azteca & $\begin{array}{l}\mathrm{LC}_{50}(48 \mathrm{~h}) \\
\text { (mortality) }\end{array}$ & $29.8 \mathrm{mgL}^{-1}$ & [172] \\
\hline & & Surface water & & & & $<10-37$ & & & & & & \\
\hline & & & & & & & & & & $\begin{array}{l}\text { NOEC (27 d) } \\
\text { (reproduction) }\end{array}$ & $0.001 \mathrm{mg} \mathrm{L}^{-1}$ & [172] \\
\hline
\end{tabular}




\begin{tabular}{|c|c|c|c|c|c|c|c|c|c|c|c|c|}
\hline & & & & & & & & & & $\begin{array}{l}\text { LOEC (27d) } \\
\text { (reproduction) }\end{array}$ & $0.1 \mathrm{mgL}^{-1}$ & [172] \\
\hline & & & & & & & & & C. dudia & $\begin{array}{l}\mathrm{LC}_{50}(48 \mathrm{~h}) \\
\text { (mortality) }\end{array}$ & $0.8 \mathrm{mgL}^{-1}$ & [172] \\
\hline & & & & & & & & & & $\begin{array}{l}\text { NOEC }(7 \mathrm{~d}) \\
\text { (reproduction) }\end{array}$ & $0.125 \mathrm{mg} \mathrm{L}^{-1}$ & [172] \\
\hline & & & & & & & & & & $\begin{array}{l}\mathrm{LOEC}(7 \mathrm{~d}) \\
\text { (reproduction) }\end{array}$ & $0.25 \mathrm{mgL}^{-1}$ & [172] \\
\hline & & & & & & & & & D. magna & $\begin{array}{l}\mathrm{LC}_{50}(48 \mathrm{~h}) \\
\text { (mortality) }\end{array}$ & $1.6 \mathrm{mgL}^{-1}$ & [172] \\
\hline & & & & & & & & Fish & O. latipes & $\begin{array}{l}\mathrm{LC}_{50}(48 \mathrm{~h}) \\
\text { (mortality) }\end{array}$ & $24.3 \mathrm{mgL}^{-1}$ & [172] \\
\hline & & & & & & & & Algae & D. subspicatus & $\begin{array}{l}\mathrm{EC}_{50}(48 \mathrm{~h}) \text { (growth } \\
\text { inhibition) }\end{array}$ & $0.7 \mathrm{mgL}^{-1}$ & [175] \\
\hline & & & & & & & & Crustacean & D. magna & $\begin{array}{l}\mathrm{EC}_{50}(48 \mathrm{~h}) \\
\text { (immobilization) }\end{array}$ & $7.7 \mathrm{mgL}^{-1}$ & [175] \\
\hline & & & & & & & & Duckweed & L. minor & $\mathrm{EC}_{50}$ (growth rate) & $113 \mathrm{mgL}^{-1}$ & [175] \\
\hline & & & & & & & & Crustacean & D. magna & $\begin{array}{l}\text { NOEC (9d)(body } \\
\text { mass) }\end{array}$ & $0.22 \mathrm{mg} \mathrm{L}^{-1}$ & [176] \\
\hline & & & & & & & & & & $\begin{array}{l}\text { LOEC }(9 \mathrm{~d})(\text { body } \\
\text { mass) }\end{array}$ & $0.44 \mathrm{mg} \mathrm{L}^{-1}$ & [176] \\
\hline & & & & & & & & & & $\begin{array}{l}\operatorname{NOEC}(9 \mathrm{~d}) \\
\text { (reproduction) }\end{array}$ & $0.055 \mathrm{mg} \mathrm{L}^{-1}$ & [176] \\
\hline & & & & & & & & & & $\begin{array}{l}\text { LOEC }(9 \mathrm{~d}) \\
\text { (reproduction) }\end{array}$ & $0.11 \mathrm{mg} \mathrm{L}^{-1}$ & [176] \\
\hline & & & & & & & & & & $\begin{array}{l}\operatorname{LOEC}(9 \mathrm{~d}) \text { (heart } \\
\text { rate) }\end{array}$ & $0.055 \mathrm{mg} \mathrm{L}^{-1}$ & [176] \\
\hline Sotalol & 959-24-0 & STP influent & Finland & $\begin{array}{l}\text { SPE- } \\
\text { HPLC-MS/MS }\end{array}$ & 3.9 & $640-830$ & [16] & & & & & \\
\hline & & STPeffluent & & & & $160-300$ & & & & & & \\
\hline & & $\begin{array}{l}\text { Vantaa river } \\
\text { water }\end{array}$ & & & & $<3.9-52$ & & & & & & \\
\hline & & $\begin{array}{l}\text { Luhtajoki } \\
\text { river water }\end{array}$ & & & & 37 & & & & & & \\
\hline Sotalol & & Groundwater & Germany & $\begin{array}{l}\text { SPE- } \\
\text { HPLC-MS/MS }\end{array}$ & 8.0 & 560 & [26] & & & & & \\
\hline
\end{tabular}

Detection. 


\subsection{Antidepressants}

Serotonin (or 5-hydroxytryptamine) is an important neurotransmitter in hormonal and neuronal mechanisms. It participates in different regulatory and endocrine functions so that altered lev- els may cause changes in appetite, immune system, reproduction and other behavioural functions [10,35]. It is also important to lower vertebrates and invertebrates though being associated with different physiological mechanisms from those observed for mam- mals. In therapeutics, the selective serotonin reuptake inhibitors (SSRIs) fluoxetine, fluvoxamine, paroxetine and sertraline are the most widely used synthetic antidepressants. They act by inhibit- ing the reuptake of serotonin from the pre-synaptic nerve cleft. It is thus obvious that from the presence of SSRIs in the envi- ronment (even at low concentrations (ng or $\left.\mu \mathrm{g} \mathrm{L}^{-1}\right)$ ), adverse effects on aquatic organisms could arise [177]. In fact, fluvox- amine at a concentration of $0.32 \mu \mathrm{g} \mathrm{L}^{-1}$ or fluoxetine at higher concentrations were capable of inducing spawning and oocyte maturation of zebra mussels (Dreissena polymorpha) [178]. On the contrary, a NOEC value of $0.47 \mu \mathrm{g} \mathrm{L}^{-1}$ was deduced for the ability of fluoxetine to reduce reproduction of the freshwater mudsnail Pota- mopyrgus antipodarum [179]. Japanese medaka were exposed to a range of fluoxetine from 0.1 to $5 \mu \mathrm{g} \mathrm{L}^{-1}$ over four weeks, revealing that fecundity, egg fertilization and hatching success were unaf- fected. However, an increase in developmental abnormalities in fish embryos was observed and plasma estradiol concentrations were significantly raised in females [180]. Following an one-week exposure of western mosquitofish (Gambusia affinis) neonates to fluoxetine, a $\mathrm{LC}_{50}$ value of $546 \mu \mathrm{g} \mathrm{L}^{-1}$ was obtained [181]. Although chronic exposure to concentrations from 0.05 to $5 \mu \mathrm{g}$ $\mathrm{L}^{-1}$ increased lethargy, it did not affect survival, growth or sex ratio [181]. In turn,

G. affinis exposed to $71 \mu \mathrm{g} \mathrm{L}^{-1}$ of fluoxetine from juvenile through adult life stages showed a delay in the development of mature sexual morphology in both male and female fish [181].

Another SSRI, sertraline, exhibits highly toxic properties. Following a 96-h exposure of rainbow trout to sertraline, a $\mathrm{LC}_{50}$ of $0.38 \mathrm{mg} \mathrm{L}^{-1}$ was deduced [182]. The same authors also found that those surviving fish exposed to $0.32 \mathrm{mg} \mathrm{L}^{-1}$ of sertraline for $72 \mathrm{~h}$, died following irreparable physiological damage after being removed to control water. Fish exposed to higher concentrations of this pharmaceutical showed a decreased respiration and a loss of movement coordination.

SSRIs were also tested on algae by evaluating the growth inhibition induced. Chronic toxicity tests proved that the organisms were sensitive with NOEC values below $1 \mathrm{mg} \mathrm{L}^{-1}$ [52]. C. vulgaris was shown to be the least sensitive species for all SSRIs tested [183]. On the contrary, Pseudokirchneriella subcapitata was the most sensitive species mainly regarding fluoxetine with a reported $\mathrm{EC}_{50}$ of $24 \mu \mathrm{g} \mathrm{L}^{-1}$ after $48 \mathrm{~h}[177,184]$ or $45 \mu \mathrm{g} \mathrm{L}^{-1}$ when the exposure time was increased to $96 \mathrm{~h}$ [183]. Cell deformities in these green algae were noticed with just $13.6 \mu \mathrm{g} \mathrm{L}^{-1}$ of fluoxetine. Similar $\mathrm{EC}_{50}$ values were determined for acute toxic effects caused by sertra- line on $P$. subcapitata and Scenedesmus acutus (12.1 and $99 \mu \mathrm{g} \mathrm{L}^{-1}$ respectively) [183]. By reducing the exposure time from 96 to $72 \mathrm{~h}, P$. subcapitata showed an $\mathrm{EC}_{50}$ of $0.14 \mathrm{mg} \mathrm{L}^{-1}$ [182]. Fluvox- amine gave rise to the highest $\mathrm{EC}_{50}$ values for all algae species tested (3563-10,208 $\mu \mathrm{g} \mathrm{L}^{-1}$ ) [183]. An exposure of $96 \mathrm{~h}$ of the marine phytoplankton $D$. tertiolecta to fluoxetine showed an $\mathrm{EC}_{50}$ of

$169.81 \mu \mathrm{g} \mathrm{L}^{-1}$ [70], which is higher than growth rate $\mathrm{EC}_{50}$ s reported previously to algae species.

Tests performed on the invertebrates C. dubia, D. magna and on fathead minnow fish showed $\mathrm{LC}_{50}$ values of 234,820 and $705 \mu \mathrm{g} \mathrm{L}^{-1}$ respectively, after $48 \mathrm{~h}$ of exposure to fluoxetine [184]. On the other hand, for paroxetine, D. magna showed an $\mathrm{EC}_{50}$ of $2.5 \mathrm{mg} \mathrm{L}^{-1}$ [185]. Regarding the invertebrates, fluoxetine may cause a stimu- lation of reproduction as is the case of C. dubia when exposed to
$56 \mu \mathrm{g} \mathrm{L}^{-1}$ of this pharmaceutical [184]. This same effect was also found for D. magna after 30 days of exposure to a concentration of 36 $\mu \mathrm{g} \mathrm{L}^{-1}$ [116] which resulted in an increase in total number of offspring produced. Higher concentrations of fluoxetine were tested (e.g. $223 \mu \mathrm{g}$ $\mathrm{L}^{-1}$ ) and proven to exert the opposite effect [184] in a similar way to that observed for sertraline, exhibiting an $\mathrm{EC}_{50}$ of $0.066 \mathrm{mg} \mathrm{L}^{-1}$ and a LOEC of $0.1 \mathrm{mg} \mathrm{L}^{-1}$ [182]. A multi- generational study was performed by exposing $D$. magna and their newborns to fluoxetine [33]. The highest effects were found on the development of the embryos. The newborns length was affected $\left(\mathrm{NOEC}=8.9 \mu \mathrm{g} \mathrm{L}^{-1}\right.$ and $\left.\mathrm{LOEC}=31 \mu \mathrm{g} \mathrm{L}^{-1}\right)$, what had consequences in their future reproduction, that was significantly reduced for a concentration of $31 \mu \mathrm{g} \mathrm{L}^{-1}$ [33]. The exposure of the invertebrate

$P$. antipodarum to fluoxetine caused a decrease in reproduction, resulting in a NOEC of $13 \mu \mathrm{g} \mathrm{L}^{-1}$ and a LOEC of $69 \mu \mathrm{g} \mathrm{L}^{-1}$ [33]. In contrast, $H$. azteca reproduction was not affected by this SSRI, buta significant effect on growth was noticed, showing a NOEC and a LOEC of 33 and $100 \mu \mathrm{g}$ $\mathrm{L}^{-1}$, respectively [33].

The behaviour of aquatic invertebrates was also shown to be affected by SSRIs as illustrated by the amphipod G. pulex in the presence of 10 and $100 \mathrm{ng} \mathrm{L}^{-1}$ of fluoxetine [76]. Fairy shrimps $T$. platyurus are more sensitive to sertraline compared to D. magna. For the former an $\mathrm{EC}_{50}$ of $0.6 \mathrm{mg} \mathrm{L}^{-1}$ after $24 \mathrm{~h}$ was obtained and with $D$. magna corresponding $\mathrm{EC}_{50}$ values were 3.1 and $1.3 \mathrm{mg} \mathrm{L}^{-1}$ after 24 and $48 \mathrm{~h}$, respectively [182]. Nematoceran flies Chirono-mus tentans and hydras $H$. azteca were exposed to fluoxetineby sediments, showing growth inhibition with LOECs of 1.3 and

$5.6 \mathrm{mg} \mathrm{kg}^{-1}$ respectively [184]. However, hydras reproduction was stimulated for all concentrations tested $\left(1.4-22.4 \mathrm{mg} \mathrm{kg}^{-1}\right)$ as well as blackworms Lumbriculus variegatus when exposed to 0.94 and $2.34 \mathrm{mg} \mathrm{kg}^{-1}$ of fluoxetine [179]. In C. tentans, this kind of exposure caused a reduction in emergence with a LOEC of $1.12 \mathrm{mg} \mathrm{kg}^{-1}$. On the other hand, Péry et al. [33] did not observed toxic effects on C.riparius growth, emergence and reproduction, even when exposedto $59.5 \mathrm{mg} \mathrm{kg}^{-1}$ of fluoxetine.

SSRIs contaminate different aquatic environments at concentra- tions in the order of ng $\mathrm{L}^{-1}$ (Table 7). Fluoxetine is a typical example, being detected in STP influents at concentrations of $0.4-18.7 \mathrm{ng} \mathrm{L}^{-1}$ and in effluents in the lower range of $0.12-8.4 \mathrm{ng} \mathrm{L}^{-1}$ [186-188]. This pharmaceutical was also detected in surface waters [23,188], groundwaters [28] and drinking water [32]. Other SSRIs, such as fluvoxamine, sertraline and paroxetine have also been detected in STP influents and effluents [186-188] as well as seawater (Nor- way) [187]. Antidepressants were detected at low concentrations $\left(\mathrm{ng} \mathrm{L}^{-1}\right)$ which may not represent isolated threats to non-target organisms when considering the respective contribution. However, since they exert similar effects and are present in the environ- ment as a mixture, it is possible that chronic exposure of aquatic organisms may induce toxicity.

\subsection{Antineoplasics}

Antineoplasic drugs are designed to kill cells that are prolif- erating excessively such as those found in pathological cancer conditions. Therefore, a similar effect on any other growing eukary-otic organisms is expected [189]. Pharmaceuticals belonging to this therapeutic class possess genotoxic, mutagenic, carcinogenic, ter-atogenic and fetotoxic properties and can constitute (in their native form) from 14 to $53 \%$ of the administered drug excreted in urine [108]. Cyclophosphamide and ifosfamide ecotoxicity predicted by ECOSAR have yielded $\mathrm{EC}_{50}$ values of 8.2 and $70 \mathrm{mg} \mathrm{L}^{-1}$ for algae and fish respectively, whereas the freshwater flea D. magna reg-istered a $\mathrm{LC}_{50}$ of $1795 \mathrm{mg} \mathrm{L}^{-1}$ [108]. Toxicity tests performed onthe algae $P$. subcapitata and the invertebrate D. magna showed that cyclophosphamide slightly increased the growth of the former(NOEC above $100 \mathrm{mg} \mathrm{L}^{-1}$ ) and reduced offspring number in the lat- 
Table 7

Examples of concentrations $\left(\mathrm{ng} \mathrm{L}^{-1}\right)$ of antidepressants measured in different aquatic environments.

\begin{tabular}{|c|c|c|c|c|c|c|c|c|c|c|c|c|}
\hline Compound & CAS number & Sample & Country & $\begin{array}{l}\text { Analytical } \\
\text { procedure }\end{array}$ & $\operatorname{LOD}\left(\mathrm{ngL}^{-1}\right)$ & $\begin{array}{l}\text { Concentration } \\
\text { reported }\left(\mathrm{ngL}^{-1}\right)\end{array}$ & Ref. & Taxon & Species & $\begin{array}{l}\text { Toxicological } \\
\text { endpoint }\end{array}$ & $\begin{array}{l}\text { Ecotoxicity } \\
\text { data }\end{array}$ & Ref. \\
\hline \multirow[t]{3}{*}{ Amitriptyline } & $-t$ & STP influent & Canada & SPE-LC-MS/MS & 0.077 & $\begin{array}{l}17.6( \pm 0.8)-20.8 \\
( \pm 1.2)\end{array}$ & [188] & & & & & \\
\hline & & STPeffluent & & & & $15.6( \pm 0.8)-21.0$ & & & & & & \\
\hline & & St. Lawrence & & & & $\begin{array}{l} \pm 1.5) \\
0.87( \pm 0.07)-3.7\end{array}$ & & & & & & \\
\hline \multirow[t]{4}{*}{ Nortriptyline* } & $-t$ & $\begin{array}{l}\text { River water } \\
\text { STP influent }\end{array}$ & Canada & SPE-LC-MS/MS & 0.057 & $\begin{array}{l}( \pm 0.2) \\
3.1( \pm 0.1)-4.5 \\
( \pm 0.4)\end{array}$ & [188] & & & & & \\
\hline & & STPeffluent & & & & $1.5( \pm 0.1)-3.8$ & & & & & & \\
\hline & & St. Lawrence & & & & $\begin{array}{l}( \pm 0.4) \\
0.41\end{array}$ & & & & & & \\
\hline & & River water & & & & $( \pm 0.02)-0.73$ & & & & & & \\
\hline \multirow[t]{2}{*}{ Citalopram } & $59729-33-8$ & STP influent & Norway & SPE-HPLC-MS & 0.16 & $\begin{array}{l}( \pm 0.06) \\
13.0-612\end{array}$ & [186] & & & & & \\
\hline & & STPeffluent & & & & $9.2-382$ & & & & & & \\
\hline \multirow[t]{4}{*}{ Citalopram } & & STP influent & Norway & HF-LPME- & 0.017 & 62.9 & [187] & & & & & \\
\hline & & & & HPLC-MS & & $\begin{array}{l}( \pm 30.7)-303.6 \\
( \pm 4.3)\end{array}$ & & & & & & \\
\hline & & STPeffluent & & & & 21.9 & & & & & & \\
\hline & & & & & & $\begin{array}{l}( \pm 13.5)-238.4 \\
( \pm 23.6)\end{array}$ & & & & & & \\
\hline \multirow{3}{*}{ Citalopram } & & STP influent & Canada & SPE-LC-MS/MS & 0.077 & $\begin{array}{l}52.2( \pm 3.7)-52.7 \\
( \pm 4.9)\end{array}$ & [188] & & & & & \\
\hline & & STP effluent & & & & $\begin{array}{l}46.8( \pm 1.2)-57.8 \\
( \pm 0.3)\end{array}$ & & & & & & \\
\hline & & St. Lawrence & & & & $3.4( \pm 0.2)-11.5$ & & & & & & \\
\hline Fluoxetine & $54910-89-3$ & $\begin{array}{l}\text { River water } \\
\text { Surface water }\end{array}$ & USA & SPE-LC-MS & 18 & $( \pm 0.8)$ & {$[23]$} & Amphipod & H. azteca & LOEC (28 d) (growth) & $100 \mu \mathrm{gL}^{-1}$ & - \\
\hline Fluoxetine & $34=10-09=5$ & Groundwater & USA & SPE-HPLC-MS & 18 & 56 & {$[28]$} & 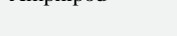 & & $\operatorname{NOEC}(28 \mathrm{~d})$ (growth) & $33 \mu \mathrm{gL}^{-1}$ & {$[33]$} \\
\hline Fluoxetine & & $\begin{array}{l}\text { Drinking } \\
\text { water }\end{array}$ & USA & SPE-LC-MS/MS & 0.50 & 0.64 & [32] & Crustacean & D. magna & $\begin{array}{l}\text { NOEC }(21 \mathrm{~d}) \\
\text { (newbornes lenght) }\end{array}$ & $8.9 \mu \mathrm{gL}^{-1}$ & [33] \\
\hline \multirow[t]{2}{*}{ Fluoxetine } & & STPeffluent & South Korea & SPE-LC-MS/MS & 1.0 & 1.7 & [90] & & & $\begin{array}{l}\text { LOEC (21 d) } \\
\text { (newbornes lenght) }\end{array}$ & $31 \mu \mathrm{gL}^{-1}$ & [33] \\
\hline & & Surface water & & & & ND & & & & & & \\
\hline Fluoxetine & & $\begin{array}{l}\text { STP influent } \\
\text { STPeffluent }\end{array}$ & Norway & SPE-HPLC-MS & 0.12 & $\begin{array}{l}0.4-2.4 \\
<0.12-1.3\end{array}$ & [186] & Freshwater snail & P. antipodarum & NOEC (reproduction) & $13 \mu \mathrm{gL}^{-1}$ & [33] \\
\hline \multirow[t]{2}{*}{ Fluoxetine } & & STPinfluent & Norway & $\begin{array}{l}\text { HF-LPME- } \\
\text { HPLC-MS }\end{array}$ & 0.15 & $\begin{array}{l}1.1( \pm 22.9)-18.7 \\
( \pm 0.9)\end{array}$ & [187] & & & LOEC (reproduction) & $69 \mu \mathrm{gL}^{-1}$ & [33] \\
\hline & & STPeffluent & & & & $\begin{array}{l}0.6( \pm 20.0)-8.4 \\
( \pm 22.9)\end{array}$ & & & & & & \\
\hline \multirow[t]{8}{*}{ Fluoxetine } & & STP influent & Canada & SPE-LC-MS/MS & 0.05 & $\begin{array}{l}( \pm 22.9) \\
3.1( \pm 0.3)-3.5 \\
( \pm 0.3)\end{array}$ & [188] & Crustacean & $\begin{array}{l}\text { Gammarus } \\
\text { pulex }\end{array}$ & LOEC (behaviour) & $100 \mathrm{ng} \mathrm{L}^{-1}$ & [76] \\
\hline & & STP effluent & & & & $\begin{array}{l}2.0( \pm 0.1)-3.7 \\
( \pm 0.1)\end{array}$ & & & & & & \\
\hline & & St. Lawrence & & & & $0.42( \pm 0.01)-1.3$ & & & & & & \\
\hline & & River water & & & & $( \pm 0.1)$ & & Algae & $\begin{array}{l}\text { Dunaliella } \\
\text { tertiolecta }\end{array}$ & $\begin{array}{l}\mathrm{EC}_{50}(96 \mathrm{~h}) \text { (growth } \\
\text { inhibition) }\end{array}$ & $169.81 \mu \mathrm{g} \mathrm{L}^{-1}$ & [70] \\
\hline & & & & & & & & & P. subcapitata & $\begin{array}{l}\mathrm{EC}_{50}(120 \mathrm{~h})(\text { growth }) \\
\text { LOEC (growth) }\end{array}$ & $24 \mu \mathrm{gL}^{-1}$ & {$[17] 7$} \\
\hline & & & & & & & & Crustacean & C. dubia & $\mathrm{LC}_{50}(48 \mathrm{~h})$ & $\begin{array}{l}13.6 \mu \mathrm{gL}^{-1} \\
234 \mu \mathrm{gL} \mathrm{L}^{-1}\end{array}$ & [177] \\
\hline & & & & & & & & & & NOEC & $56 \mu \mathrm{gL}^{-1}$ & [177] \\
\hline & & & & & & & & & & LOEC & $112 \mu \mathrm{gL}^{-1}$ & [177] \\
\hline
\end{tabular}


Table 7 (Continued)

\begin{tabular}{|c|c|c|c|c|c|c|c|c|c|c|c|c|}
\hline Compound & CAS number & Sample & Country & $\begin{array}{l}\text { Analytical } \\
\text { procedure }\end{array}$ & $\operatorname{LOD}\left(\mathrm{ngL}^{-1}\right)$ & $\begin{array}{l}\text { Concentration } \\
\text { reported }\left(\mathrm{ngL}^{-1}\right)\end{array}$ & Ref. & Taxon & Species & $\begin{array}{l}\text { Toxicological } \\
\text { endpoint }\end{array}$ & $\begin{array}{l}\text { Ecotoxicity } \\
\text { data }\end{array}$ & Ref. \\
\hline & & & & & & & & & D. magna & $\mathrm{LC}_{50}(48 \mathrm{~h})$ & $820 \mu \mathrm{gL}^{-1}$ & [177] \\
\hline & & & & & & & & Fish & P. pimelas & $\mathrm{LC}_{50}(48 \mathrm{~h})$ & $705 \mu \mathrm{gL}^{-1}$ & [177] \\
\hline & & & & & & & & Midge & C. tentans & $\mathrm{LC}_{50}(10 \mathrm{~d})$ & $15.2 \mathrm{mg} \mathrm{kg}^{-1}$ & [177] \\
\hline & & & & & & & & & & LOEC (10d) (growth) & $1.3 \mathrm{mg} \mathrm{kg}^{-1}$ & [177] \\
\hline & & & & & & & & Amphipod & H. azteca & LOEC (growth) & $5.4 \mathrm{mg} \mathrm{kg}^{-1}$ & [177] \\
\hline & & & & & & & & Freshwater snail & P. antipodarum & $\begin{array}{l}\mathrm{EC}_{10}(56 \mathrm{~d})\left(\mathrm{n}^{\circ}\right. \\
\text { embryos whitout } \\
\text { shell) }\end{array}$ & $0.81 \mu \mathrm{gL}^{-1}$ & [179] \\
\hline & & & & & & & & & & $\begin{array}{l}\operatorname{NOEC}(56 \mathrm{~d})\left(\mathrm{n}^{\circ}\right. \\
\text { embryos whitout } \\
\text { shell) }\end{array}$ & $0.47 \mu \mathrm{gL}^{-1}$ & [179] \\
\hline & & & & & & & & Midge & C. riparius & $\begin{array}{l}\text { LOEC (28 d) } \\
\text { (emergence) }\end{array}$ & $1.12 \mathrm{mg} \mathrm{kg}^{-1}$ & [179] \\
\hline & & & & & & & & Mosquitofish & $\begin{array}{l}\text { Gambusia } \\
\text { affinis }\end{array}$ & LC $_{50}$ (7 d) (lethality) & $546 \mu \mathrm{g} \mathrm{L}^{-1}$ & [181] \\
\hline & & & & & & & & Algae & P. subscapitata & $\begin{array}{l}\text { IC }_{50}(96 \mathrm{~h}) \text { (growth } \\
\text { inhibition) }\end{array}$ & $44.99 \mu \mathrm{gL}^{-1}$ & [183] \\
\hline & & & & & & & & & S. acutus & $\begin{array}{l}\mathrm{IC}_{50}(96 \mathrm{~h}) \text { (growth } \\
\text { inhibition) }\end{array}$ & $91.23 \mu \mathrm{g} \mathrm{L}^{-1}$ & [183] \\
\hline & & & & & & & & & S. quadricauda & $\begin{array}{l}\mathrm{IC}_{50}(96 \mathrm{~h}) \text { (growth } \\
\text { inhibition) }\end{array}$ & $212.98 \mu \mathrm{gL}^{-1}$ & [183] \\
\hline & & & & & & & & & C. vulgaris & $\begin{array}{l}\mathrm{IC}_{50}(96 \mathrm{~h}) \text { (growth } \\
\text { inhibition) }\end{array}$ & $4339.25 \mu \mathrm{gL}^{-1}$ & [183] \\
\hline & & & & & & & & Algae & P. subscapitata & $\mathrm{EC}_{50}(120 \mathrm{~h})($ growth $)$ & $39 \mu \mathrm{gL}^{-1}$ & [184] \\
\hline & & & & & & & & Crustacean & C. dubia & $\mathrm{LC}_{50}(48 \mathrm{~h}$ ) (survival) & $234 \mu \mathrm{gL}^{-1}$ & [184] \\
\hline & & & & & & & & & D. magna & LC $_{50}(48$ h) (survival) & $820 \mu \mathrm{gL}^{-1}$ & [184] \\
\hline & & & & & & & & Fish & P. promelas & LC $_{50}(48 \mathrm{~h}$ )(survival) & $705 \mu \mathrm{g} \mathrm{L}^{-1}$ & [184] \\
\hline & & & & & & & & Midge & C. tentans & $\mathrm{LC}_{50}(10 \mathrm{~d})$ (survival) & $15.2 \mathrm{mg} \mathrm{kg}^{-1}$ & [184] \\
\hline & & & & & & & & & & LOEC (10 d) (growth) & $1.3 \mathrm{mgkg}^{-1}$ & [184] \\
\hline & & & & & & & & Amphipod & H. azteca & LOEC (10d) (growth) & $5.6 \mathrm{mg} \mathrm{kg}^{-1}$ & [184] \\
\hline Norfluoxetine* & 83891-03-6 & $\begin{array}{l}\text { Drinking } \\
\text { water }\end{array}$ & USA & SPE-LC-MS/MS & 0.50 & 0.77 & [32] & & & & & \\
\hline \multirow[t]{2}{*}{ Norfluoxetine* } & & STP influent & Norway & HF-LPME- & 0.16 & $0.7( \pm 13.1)-9.3$ & [187] & & & & & \\
\hline & & STPeffluent & & HPLC-MS & $0.54(\mathrm{LOQ})$ & $\begin{array}{l}( \pm 4.6) \\
<0.54-2.4\end{array}$ & & & & & & \\
\hline \multirow[t]{2}{*}{ Norfluoxetine* } & & STP influent & Canada & SPE-LC-MS/MS & 0.087 & $\begin{array}{l}( \pm 14.5) \\
1.8( \pm 0.3)-4.2 \\
( \pm 0.5)\end{array}$ & [188] & & & & & \\
\hline & & STPeffluent & & & & $\begin{array}{l}1.7( \pm 0.1)-1.8 \\
( \pm 0.3)\end{array}$ & & & & & & \\
\hline \multirow[t]{2}{*}{ Fluvoxamine } & $54739-18-3$ & $\begin{array}{l}\text { St. Lawrence } \\
\text { River water } \\
\text { STP influent }\end{array}$ & Norway & SPE-HPLC-MS & 0.15 & $\begin{array}{l}1.2( \pm 0.1)-1.3 \\
( \pm 0.1) \\
0.4-3.9\end{array}$ & [186] & Algae & P. subscapitata & $\begin{array}{l}\text { IC }_{50}(96 \mathrm{~h}) \text { (growth } \\
\text { inhibition) }\end{array}$ & $4002.88 \mu \mathrm{gL}^{-1}$ & [183] \\
\hline & & STP effluent & & & & $<0.15-0.8$ & & & & & & \\
\hline \multirow[t]{5}{*}{ Fluvoxamine } & & STP influent & Norway & $\begin{array}{l}\text { HF-LPME- } \\
\text { HPLC-MS }\end{array}$ & 0.129 & $0.8( \pm 38.2)-1.7$ & [187] & & S. acutus & $\begin{array}{l}\mathrm{IC}_{50}(96 \mathrm{~h}) \text { (growth } \\
\text { inhibition) }\end{array}$ & $3620.24 \mu \mathrm{gL}^{-1}$ & [183] \\
\hline & & STPeffluent & & & $0.379(\mathrm{LOQ})$ & $<0.379-0.8$ & & & & & & \\
\hline & & Seawater & & & & $\begin{array}{l}( \pm 38.2) \\
0.5( \pm 0.5)-0.8\end{array}$ & & & & & & \\
\hline & & & & & & $( \pm 0.3)$ & & & S. quadricauda & $\begin{array}{l}\text { IC }_{50}(96 \mathrm{~h}) \text { (growth } \\
\text { inhibition) }\end{array}$ & $3563.34 \mu \mathrm{gL}^{-1}$ & [183] \\
\hline & & & & & & & & & C. vulgaris & $\begin{array}{l}\text { IC }_{50}(96 \mathrm{~h}) \text { (growth } \\
\text { inhibition) }\end{array}$ & $10,208.47 \mu \mathrm{g} \mathrm{L}^{-}$ & ${ }^{1}[183]$ \\
\hline
\end{tabular}




\begin{tabular}{|c|c|c|c|c|c|c|c|c|c|c|c|c|}
\hline \multirow[t]{2}{*}{ Paroxetine } & 61869-08-7 & STP influent & Norway & SPE-HPLC-MS & 0.12 & $0.6-12.3$ & [186] & Crustacean & D. magna & $\begin{array}{l}\mathrm{EC}_{50}(48 \mathrm{~h}) \\
\text { (immobilization) }\end{array}$ & $2.5 \mathrm{mgL}^{-1}$ & [185] \\
\hline & & STPeffluent & & & & $0.5-1.6$ & & & & & & \\
\hline \multirow[t]{3}{*}{ Paroxetine } & & STP influent & Norway & $\begin{array}{l}\text { HF-LPME- } \\
\text { HPLC-MS }\end{array}$ & 0.053 & $\begin{array}{l}2.9( \pm 19.0)-12.9 \\
( \pm 29.4)\end{array}$ & [187] & & & & & \\
\hline & & STP effluent & & & & $\begin{array}{l}1.0( \pm 15.7)-11.7 \\
( \pm 36.8)\end{array}$ & & & & & & \\
\hline & & Seawater & & & & $\begin{array}{l}0.6( \pm 0.4)-1.4 \\
( \pm 0.4)\end{array}$ & & & & & & \\
\hline \multirow[t]{3}{*}{ Paroxetine } & & STP influent & Canada & SPE-LC-MS/MS & 0.096 & $\begin{array}{l}4.6( \pm 0.3)-5.3 \\
( \pm 0.2)\end{array}$ & [188] & & & & & \\
\hline & & STP effluent & & & & $\begin{array}{l}4.3( \pm 0.2)-5.2 \\
( \pm 0.5)\end{array}$ & & & & & & \\
\hline & & St. Lawrence & & & & $1.3( \pm 0.1)-3.0$ & & & & & & \\
\hline \multirow[t]{2}{*}{ Sertraline } & 79617-96-2 & $\begin{array}{l}\text { River water } \\
\text { STP influent }\end{array}$ & Norway & SPE-HPLC-MS & 0.29 & $\begin{array}{l}( \pm 0.1) \\
1.8-2.5\end{array}$ & {$[186]$} & Bacteria & V. fischeri & $\begin{array}{l}\mathrm{EC}_{50}(30 \mathrm{~min}) \\
\text { (inhibition) }\end{array}$ & $10.72 \mathrm{mg} \mathrm{L}^{-1}$ & [182] \\
\hline & & STPeffluent & & & & $0.9-2.0$ & & & & & & \\
\hline \multirow[t]{3}{*}{ Sertraline } & & STP influent & Norway & $\begin{array}{l}\text { HF-LPME- } \\
\text { HPLC-MS }\end{array}$ & 0.16 & $\begin{array}{l}8.4( \pm 4.5)-19.8 \\
( \pm 10.8)\end{array}$ & [187] & & & $\begin{array}{l}\text { NOEC ( } 30 \mathrm{~min}) \\
\text { (inhibition) }\end{array}$ & $2.25 \mathrm{mgL}^{-1}$ & [182] \\
\hline & & STP effluent & & & $0.52(\mathrm{LOQ})$ & $3.7( \pm 16.3)-14.6$ & & & & & & \\
\hline & & Seawater & & & & $\begin{array}{l}( \pm 4.2) \\
<0.52\end{array}$ & & & & & & \\
\hline \multirow[t]{19}{*}{ Sertraline } & & STP influent & Canada & SPE-LC-MS/MS & 0.048 & $\begin{array}{l}6.0( \pm 0.4)-6.1 \\
( \pm 0.3)\end{array}$ & {$[188]$} & & & $\begin{array}{l}\text { LOEC ( } 30 \mathrm{~min}) \\
\text { (inhibition) }\end{array}$ & $4.5 \mathrm{mgL}^{-1}$ & [182] \\
\hline & & STP effluent & & & & $\begin{array}{l}5.1( \pm 0.3)-5.8 \\
( \pm 0.8)\end{array}$ & & & & & & \\
\hline & & St. Lawrence & & & & $0.84( \pm 0.09)-2.4$ & & & & & & \\
\hline & & River water & & & & $( \pm 0.1)$ & & Algae & P. subcapitata & $\begin{array}{l}\mathrm{EC}_{50}(72 \mathrm{~h}) \\
\text { (inhibition) }\end{array}$ & $0.14 \mathrm{mgL}^{-1}$ & [182] \\
\hline & & & & & & & & & & $\begin{array}{l}\text { NOEC (72h) } \\
\text { (inhibition) }\end{array}$ & $0.05 \mathrm{mgL}^{-1}$ & [182] \\
\hline & & & & & & & & & & $\begin{array}{l}\operatorname{LOEC}(72 \mathrm{~h}) \\
\text { (inhibition) }\end{array}$ & $0.075 \mathrm{mg} \mathrm{L}^{-1}$ & [182] \\
\hline & & & & & & & & Shrimp & T. platyurus & LC $_{50}(24$ h)(lethality) & $0.6 \mathrm{mgL}^{-1}$ & [182] \\
\hline & & & & & & & & & & $\begin{array}{l}\operatorname{NOEC}(24 \mathrm{~h}) \\
\text { (lethality) }\end{array}$ & $0.4 \mathrm{mgL}^{-1}$ & [182] \\
\hline & & & & & & & & & & $\operatorname{LOEC}(24 \mathrm{~h})$ (lethality) & $0.6 \mathrm{mgL}^{-1}$ & [182] \\
\hline & & & & & & & & Crustacean & D. magna & $\begin{array}{l}\mathrm{EC}_{50}(48 \mathrm{~h}) \\
\text { (immobilization) }\end{array}$ & $1.3 \mathrm{mgL}^{-1}$ & [182] \\
\hline & & & & & & & & & & $\begin{array}{l}\text { NOEC (48h) } \\
\text { (immobilization) }\end{array}$ & $0.10 \mathrm{mgL}^{-1}$ & [182] \\
\hline & & & & & & & & & & $\begin{array}{l}\text { LOEC (48h) } \\
\text { (immobilization) }\end{array}$ & $0.18 \mathrm{mgL}^{-1}$ & [182] \\
\hline & & & & & & & & & & $\begin{array}{l}\mathrm{EC}_{50}(21 \mathrm{~d}) \\
\text { (reproduction) }\end{array}$ & $0.066 \mathrm{mgL}^{-1}$ & [182] \\
\hline & & & & & & & & & & $\begin{array}{l}\text { NOEC (21 d) } \\
\text { (reproduction) }\end{array}$ & $0.032 \mathrm{mg} \mathrm{L}^{-1}$ & [182] \\
\hline & & & & & & & & & & $\begin{array}{l}\text { LOEC (21 d) } \\
\text { (reproduction) }\end{array}$ & $0.1 \mathrm{mgL}^{-1}$ & [182] \\
\hline & & & & & & & & & & $\mathrm{LC}_{50}(21 \mathrm{~d})$ (lethality) & $0.12 \mathrm{mgL}^{-1}$ & [182] \\
\hline & & & & & & & & & & $\begin{array}{l}\text { NOEC (21 d) } \\
\text { (lethality) }\end{array}$ & $0.032 \mathrm{mg} \mathrm{L}^{-1}$ & [182] \\
\hline & & & & & & & & & & LOEC (21 d) (lethality) & $0.1 \mathrm{mgL}^{-1}$ & {$[182]$} \\
\hline & & & & & & & & Fish & O. mykiss & $\begin{array}{l}\mathrm{LC}_{50}(96 \mathrm{~h}) \text { (lethality) } \\
\text { NOEC }(96 \mathrm{~h}) \\
\text { (lethality) }\end{array}$ & $\begin{array}{l}0.38 \mathrm{mgL}^{-1} \\
0.1 \mathrm{mLL}^{-1}\end{array}$ & $\begin{array}{l}{[182]} \\
{[182]}\end{array}$ \\
\hline
\end{tabular}




\begin{tabular}{|c|c|c|c|c|c|c|c|c|c|c|c|c|}
\hline Compound & CAS number & Sample & Country & $\begin{array}{l}\text { Analytical } \\
\text { procedure }\end{array}$ & $\operatorname{LOD}\left(\mathrm{ngL}^{-1}\right)$ & $\begin{array}{l}\text { Concentration } \\
\text { reported }\left(\mathrm{ngL}^{-1}\right)\end{array}$ & Ref. & Taxon & Species & $\begin{array}{l}\text { Toxicological } \\
\text { endpoint }\end{array}$ & $\begin{array}{l}\text { Ecotoxicity } \\
\text { data }\end{array}$ & Ref. \\
\hline & & & & & & & & & & $\begin{array}{l}\text { NOEC }(96 \mathrm{~h}) \\
\text { (lethality) }\end{array}$ & $0.32 \mathrm{mg} \mathrm{L}^{-1}$ & [182] \\
\hline & & & & & & & & Algae & P. subcapitata & $\begin{array}{l}\mathrm{IC}_{50}(96 \mathrm{~h}) \text { (growth } \\
\text { inhibition) }\end{array}$ & $12.10 \mu \mathrm{gL}^{-1}$ & [183] \\
\hline & & & & & & & & & S. acutus & $\begin{array}{l}\mathrm{IC}_{50}(96 \mathrm{~h}) \text { (growth } \\
\text { inhibition) }\end{array}$ & $98.92 \mu \mathrm{gL}^{-1}$ & [183] \\
\hline & & & & & & & & & S. quadricauda & $\begin{array}{l}\text { IC }_{50}(96 \mathrm{~h}) \text { (growth } \\
\text { inhibition) }\end{array}$ & $317.02 \mu \mathrm{g} \mathrm{L}^{-1}$ & [183] \\
\hline & & & & & & & & & C. vulgaris & $\begin{array}{l}\text { IC }_{50}(96 \mathrm{~h}) \text { (growth } \\
\text { inhibition) }\end{array}$ & $763.66 \mu \mathrm{gL}^{-1}$ & [183] \\
\hline \multirow[t]{3}{*}{ Desmethylsertraline* } & $87857-41-8$ & STP influent & Canada & SPE-LC-MS/MS & 0.072 & $\begin{array}{l}4.2( \pm 0.6)-5.0 \\
( \pm 0.8)\end{array}$ & [188] & & & & & \\
\hline & & STP effluent & & & & $\begin{array}{l}3.6( \pm 0.3)-4.7 \\
( \pm 0.5)\end{array}$ & & & & & & \\
\hline & & St. Lawrence & & & & $2.3( \pm 0.1)-4.5$ & & & & & & \\
\hline \multirow[t]{5}{*}{ Venlafaxine } & $99300-78-4$ & $\begin{array}{l}\text { River water } \\
\text { STP influent }\end{array}$ & Canada & SPE-LC-MS/MS & 0.10 & $\begin{array}{l}( \pm 0.4) \\
195.7\end{array}$ & [188] & & & & & \\
\hline & & & & & & $( \pm 25.3)-213.0$ & & & & & & \\
\hline & & STPeffluent & & & & $\begin{array}{l}( \pm 8.2) \\
175.9\end{array}$ & & & & & & \\
\hline & & & & & & $\begin{array}{l}( \pm 12.7)-214.6 \\
( \pm 3.6)\end{array}$ & & & & & & \\
\hline & & St. Lawrence & & & & $12.9( \pm 0.1)-45.9$ & & & & & & \\
\hline \multirow[t]{6}{*}{ Desmethylvenlafaxine* } & -+ & $\begin{array}{l}\text { River water } \\
\text { STP influent }\end{array}$ & Canada & SPE-LC-MS/MS & 0.097 & $\begin{array}{l}( \pm 2.0) \\
274.3\end{array}$ & [188] & & & & & \\
\hline & & & & & & $\begin{array}{l}( \pm 26.5)-345.9 \\
( \pm 19.8)\end{array}$ & & & & & & \\
\hline & & STPeffluent & & & & 222.5 & & & & & & \\
\hline & & & & & & $\begin{array}{l}( \pm 16.8)-330.0 \\
( \pm 9.8)\end{array}$ & & & & & & \\
\hline & & St. Lawrence & & & & $21.0( \pm 0.5)-68.7$ & & & & & & \\
\hline & & River water & & & & $( \pm 3.1)$ & & & & & & \\
\hline
\end{tabular}

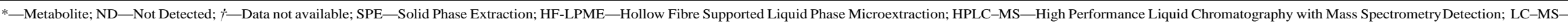
Liquid Chromatography with Mass Spectrometry Detection; LC-MS/MS - Liquid Chromatography with Tandem Mass Spectrometry Detection. 
Table 8

Examples of concentrations $\left(\mathrm{ng} \mathrm{L}^{-1}\right)$ of antineoplasic drugs measured in different aquatic environments.

\begin{tabular}{|c|c|c|c|c|c|c|c|c|c|c|c|c|}
\hline Compound & CAS number & Sample & Country & $\begin{array}{l}\text { Analytical } \\
\text { procedure }\end{array}$ & $\operatorname{LOD}\left(\mathrm{ngL}^{-1}\right)$ & $\begin{array}{l}\text { Concentration } \\
\text { reported }\left(\mathrm{ngL}^{-1}\right)\end{array}$ & Ref. & Taxon & Species & $\begin{array}{l}\text { Toxicological } \\
\text { endpoint }\end{array}$ & $\begin{array}{l}\text { Ecotoxicity } \\
\text { data }\end{array}$ & Ref. \\
\hline Cyclophosphamide & $50-18-0$ & $\begin{array}{l}\text { Somes river } \\
\text { water }\end{array}$ & Romania & SPE-GC-MS & 30 (LOQ) & $<30-64.8( \pm 8.0)$ & [20] & Algae & P. subcapitata & $\begin{array}{l}\mathrm{EC}_{50}(72 \mathrm{~h}) \text { (growth } \\
\text { inhibition) }\end{array}$ & $>100 \mathrm{mg} \mathrm{L}^{-1}$ & [190] \\
\hline Cyclophosphamide & & STPeffluent & Italy & $\begin{array}{l}\text { SPE- } \\
\text { HPLC-MS/MS }\end{array}$ & $1.9(\mathrm{LOQ})$ & $<1.9-9.0$ & [118] & & & $\begin{array}{l}\text { NOEC ( } 72 \mathrm{~h} \text { ) (growth } \\
\text { inhibition) }\end{array}$ & $>100 \mathrm{mg} \mathrm{L}^{-1}$ & [190] \\
\hline \multirow[t]{3}{*}{ Cyclophosphamide } & & STP influent & $-t$ & SPE-GC-MS & 6 & $<6-143$ & [192] & Crustacean & D. magna & $\begin{array}{l}\mathrm{EC}_{50}(21 \mathrm{~d}) \\
\text { (reproduction) }\end{array}$ & $>100 \mathrm{mg} \mathrm{L}^{-1}$ & [190] \\
\hline & & STPeffluent & & & & $6-15$ & & & & & & \\
\hline & & $\begin{array}{l}\text { Hospital } \\
\text { effluent }\end{array}$ & & & & $19-4486$ & & & & & & \\
\hline \multirow[t]{3}{*}{ Cyclophosphamide } & & STP influent & Switzerland & SPE-LC-MS/MS & 0.3 & $2.0-6$ & [193] & & & $\begin{array}{l}\operatorname{LOEC}(21 \mathrm{~d}) \\
\text { (reproduction) }\end{array}$ & $100 \mathrm{mgL}^{-1}$ & [190] \\
\hline & & STPeffluent & & & & $2.1-4$ & & & & & & \\
\hline & & & & & & & & & & $\begin{array}{l}\text { NOEC (21 d) } \\
\text { (reproduction) }\end{array}$ & $56 \mathrm{mgL}^{-1}$ & [190] \\
\hline Ifosfamide & $84711-20-6$ & $\begin{array}{l}\text { STP influent } \\
\text { STP effluent }\end{array}$ & Switzerland & SPE-LC-MS/MS & 0.3 & $\begin{array}{l}<0.3-5 \\
1.7-6\end{array}$ & [193] & & & & & \\
\hline \multirow[t]{5}{*}{ Methotrexate } & $59-05-2$ & STP effluent & Italy & $\begin{array}{l}\text { SPE- } \\
\text { HPLC-MS/MS }\end{array}$ & $0.83(\mathrm{LOQ})$ & $<0.83-12.6$ & [118] & Bacteria & V. fischeri & $\mathrm{EC}_{50}(30 \mathrm{~min})$ & $1220 \mathrm{mg} \mathrm{L}^{-1}$ & [83] \\
\hline & & & & & & & & Algae & $\begin{array}{l}\text { Scenedesmus } \\
\text { subspicatus }\end{array}$ & $\mathrm{EC}_{50}(72 \mathrm{~h})$ & $260 \mathrm{mgL}^{-1}$ & [83] \\
\hline & & & & & & & & Crustacean & D. magna & $\mathrm{EC}_{50}$ (immobilization) & $>1000 \mathrm{mgL}^{-1}$ & [83] \\
\hline & & & & & & & & Ciliates & $\begin{array}{l}\text { Tetrahymena } \\
\text { pyriformis }\end{array}$ & $\begin{array}{l}\mathrm{EC}_{50}(48 \mathrm{~h}) \text { (growth } \\
\text { inhibition) }\end{array}$ & $45 \mathrm{mgL}^{-1}$ & [83] \\
\hline & & & & & & & & Fish & D. rerio & $\mathrm{LC}_{50}(48 \mathrm{~h})$ & $85 \mathrm{mgL}^{-1}$ & [83] \\
\hline \multirow[t]{3}{*}{ Tamoxifen } & 74899-71-1 & STP influent & United Kingdom & $\begin{array}{l}\text { SPE- } \\
\text { HPLC-MS/MS }\end{array}$ & 10 & $143-215$ & [53] & Rotifer & B. calyciflorus & $\begin{array}{l}\mathrm{LC}_{50}(24 \mathrm{~h}) \\
\text { (mortality) }\end{array}$ & $0.97 \mathrm{mg} \mathrm{L}^{-1}$ & [191] \\
\hline & & STP effluent & & & & $146-369$ & & & & & & \\
\hline & & $\begin{array}{l}\text { Tyne river } \\
\text { water }\end{array}$ & & & & $27-212$ & & & & & & \\
\hline Tamoxifen & & STPeffluent & United Kingdom & $\begin{array}{l}\text { SPE- } \\
\text { HPLC-MS/MS }\end{array}$ & 10 & $<10$ & [94] & & & $\begin{array}{l}\mathrm{EC}_{50}(48 \mathrm{~h}) \\
\text { (population growth } \\
\text { inhibition) }\end{array}$ & $0.25 \mathrm{mgL}^{-1}$ & [191] \\
\hline \multirow[t]{4}{*}{ Tamoxifen } & & $\begin{array}{l}\text { Surface water } \\
\text { STP influent }\end{array}$ & United Kingdom & SPE-LC-MS/MS & 0.003 & $\begin{array}{l}<10 \\
0.2-15\end{array}$ & [194] & Crustacean & T. platyurus & $\begin{array}{l}\mathrm{LC}_{50}(24 \mathrm{~h}) \\
\text { (mortality) }\end{array}$ & $0.40 \mathrm{mgL}^{-1}$ & [191] \\
\hline & & STPeffluent & & & & $0.2-0.7$ & & & & & & \\
\hline & & & & & & & & & D. magna & $\begin{array}{l}\mathrm{EC}_{50}(24 \mathrm{~h}) \\
\text { (immobilization) }\end{array}$ & $1.53 \mathrm{mgL}^{-1}$ & [191] \\
\hline & & & & & & & & & C. dubia & $\begin{array}{l}\mathrm{EC}_{50}(7 \mathrm{~d}) \text { (population } \\
\text { growth inhibition) }\end{array}$ & $8.1 \times 10^{-4} \mathrm{mg}$ & $\left.\mathrm{L}^{-1}{ }^{1} 191\right]$ \\
\hline
\end{tabular}

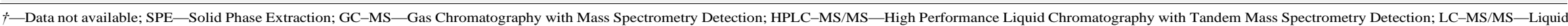
Chromatography with Tandem Mass Spectrometry Detection. 
ter at all tested concentrations of the drug (10-100 $\left.\mathrm{mg} \mathrm{L}^{-1}\right)$, with a NOEC of $56 \mathrm{mg} \mathrm{L}^{-1}$ [190]. Methotrexate revealed teratogenicity for fish embryos with an $\mathrm{EC}_{50}$ of $85 \mathrm{mg} \mathrm{L}^{-1}$ after $48 \mathrm{~h}$ of exposure [83] and acute effects in the ciliate Tetrahymena pyriformis with an $\mathrm{EC}_{50}$ for $48 \mathrm{~h}$ of $45 \mathrm{mg} \mathrm{L}^{-1}$ [83]. Acute and chronic toxicity of tamox- ifen and its photoproducts was studied by DellaGreca et al. [191], showing that both the active pharmaceutical and its photoproducts affected the rotifer $B$. calyciflorus and crustacean $T$. platyurus with $\mathrm{LC}_{50}$ values ranging from 0.95 to $1.31 \mathrm{mg} \mathrm{L}^{-1}$ and 0.40 to $1.59 \mathrm{mg} \mathrm{L}^{-1}$ respectively. In chronic toxicity tests, $C$. dubia proved the most sen- sitive organism. An $\mathrm{EC}_{50}$ value of $0.81 \mu \mathrm{g} \mathrm{L}^{-1}$ for tamoxifen and $\mathrm{EC}_{50}$ values ranging from 0.41 to $2.8 \mu \mathrm{g} \mathrm{L}^{-1}$ for its photoproducts, rela- tive to population growth inhibition, were found after a 7-day trial [191].

The antineoplasic drug cyclophosphamide has been detected in hospital effluents at concentrations ranging from $19 \mathrm{ng} \mathrm{L}^{-1}$ to $4.5 \mu \mathrm{g}$ $\mathrm{L}^{-1}$ [192], in STP influents [192,193] and effluents [118,192,193] and in surface waters [20] (Table 8). Other antineo- plasic pharmaceuticals detected to date have been in the order of $\mathrm{n} \mathrm{L}^{-1}$. However, as chronic toxicity data is very sparse, further studies are required to elucidate the potential effect of life-cycle exposure to these compounds in aquatic organisms.

\subsection{X-ray contrast media}

Contrast media are used as diagnostic tools for capturing detailed $\mathrm{X}$-ray images of soft tissues. Iodinated X-ray contrast media are highly hydrophilic substances that are widely used and eliminated almost non-metabolised. STP removal processes are usually ineffective and for this reason they persist for a long time in the environment. As X-ray contrast media do not show biolog- ical activity, their presence might not represent a threat to public health $[35,195,196]$. Toxicity tests have shown that iopromide or its main metabolite do not have a toxic effect in luminescent bacteria, algae (Scenedesmus subspicatus), daphnids or fish (D. rerio, Leuciscus idus) even at concentrations as high as $1 \mathrm{~g} \mathrm{~L}^{-1}[196,197]$. Contam- ination by X-ray contrast media has been reported in different aquatic environments (Table 9). Media have been detected in STP influents and effluents [198-201], surface waters [199,201-203], groundwaters $[26,199,200]$ and even drinking water $[200,202,203]$ at concentrations that can reach few $\mu \mathrm{g} \mathrm{L}^{-1}$. Although accepting that X-ray contrast media do not exhibit toxic effects at high con- centration levels, additional studies should be undertaken with a view to evaluating chronic effects, due to continuous exposure of aquatic organisms to these pharmaceuticals.

\subsection{Mixture effects}

Presently environmental risk assessment of pharmaceuticals is based on single compounds ecotoxicity studies. However, pharma- ceuticals do not occur alone in the environment, but as a mixture of different active substances, their metabolites and transformation products $[23,205,206]$. Ecotoxicological data showed that mixtures might have different effects than single compounds $[65,70,207]$, but in general knowledge about the toxicity of the mixture of active substances is still sparse. There are some examples of toxi- city studies in literature showing that mixture of pharmaceuticals at environmentally relevant concentrations may exhibit additive effects [70]. In some cases, lower levels than expected may lead to toxic effects when in the presence of a mixture of active sub- stances [70]. For instance, Cleuvers [65] showed that a mixture of diclofenac and ibuprofen had a stronger toxicity than predicted in

D. magna, and when the author added more two NSAIDs (naproxen and acetylsalicylic acid) to the last two, a considerable toxicity on Daphnia was also reported, even at concentrations at which the single NSAIDs do not exhibit effects [95]. The exposure of the cnidarian $H$. attenuata to a mixture of eleven pharmaceuticals, belonging to different therapeutic classes, showed also sub-lethal effects for environmentally relevant concentrations $\left(\mu \mathrm{g}-\mathrm{ng} \mathrm{L}^{-1}\right)$ [207]. Acute exposure of D. magna to a mixture of $36 \mu \mathrm{g} \mathrm{L}^{-1}$ of fluoxetine and $100 \mu \mathrm{g} \mathrm{L}^{-1}$ of clofibric acid caused a significant mor- tality and malformation, while there are no apparent effects for the same concentrations of individual pharmaceuticals [116]. The mixture of trimethoprim with sulfamethoxazole and sulfadiazine increased significantly the growth inhibition of the algae S. capri- cornutum [131]. On the other hand, the exposure of H. azteca to a mixture of seven pharmaceuticals did not reveal significant effects on their survival, mating, body size or reproduction, but there was a slight increase in the number of males [208]. Identical results were observed for fish. Apparently, a life-cycle exposure of fathead min- nows to a mixture of six pharmaceuticals, in the order of $n g \mathrm{~L}^{-1}$, did not affect their survival, growth or egg production, however it increased the number of deformities in their offspring [209]. The examples here highlighted showed that the simultaneous presence of several pharmaceuticals in the environment might result in a greater toxicity to non-target organisms than the predicted one for individual active substances. However, more ecotoxicological studies should be done to evaluate the impact of different mixtures of pharmaceuticals in non-target organisms, once that most of the published studies are focused on mixture of NSAIDs, antibioticsand blood lipid lowering agents.

\section{Pharmaceuticalsandlegislation:whatdoeslegislation say?}

Every day an increasing number of pharmaceuticals reach the environment all over the world. However, there is a gap in legisla- tion regarding environmental contamination by pharmaceuticals. This probably arises because available data is insufficient to quan- tify a precise contamination profile. Abundant conclusive studies concerning chronic toxicity are also lacking so that it becomes impossible to infer the risks of long-term exposure of pharmaceuti- cals and their metabolites on fauna and flora. In this section, EU and US laws concerning the necessity of environmental risk assessment studies to obtain a marketing authorisation for pharmaceuticals is approached.

The European Union Directive 92/18/EEC [210] introduced for the first time, the requirement for an environmental risk assess- ment, as a prerequisite to obtain marketing authorization for veterinary pharmaceuticals. Forthis purpose, theEuropean Agency for the Evaluation of Medicinal Products (EMEA) published a "Note for Guidance" [211] where guidelines to assess the environmental risk of veterinary medicinal products are established. The Euro- pean Commission extended its concerns to pharmaceuticals for human use by publishing Directive 2001/83/EC which was subse- quently amended by Directive 2004/27/EC [212]. These directives established that marketing authorization for new medical prod- ucts for human use should be accompanied by an environmental risk assessment, whose guidelines were set out by EMEA [213]. Nevertheless, the environmental impact does not provide suffi- cient grounds for a refusal. Environmental risk assessment of both veterinary and human pharmaceuticals is assessed in a step-wise approach, divided into two phases. In Phase I, environmental expo- sure to the pharmaceutical or its metabolites is estimated. Phase II comprises its fate and effects in the environment. For this reason, Phase II is sub-divided into two parts: Tier A, in which possible fate and effects of the pharmaceutical and/or its major metabolites are evaluated; and Tier B, which focuses on the effects on fauna and flora within environmental compartments that are likely to be affected [211,213]. However, medicinal products for human use 
Table 9

Examples of concentrations $\left(\mathrm{ng} \mathrm{L}^{-1}\right)$ of $\mathrm{X}$-ray contrast media measured in different aquatic environments.

\begin{tabular}{|c|c|c|c|c|c|c|c|c|c|c|c|c|}
\hline Compound & CAS number & Sample & Country & $\begin{array}{l}\text { Analytical } \\
\text { procedure }\end{array}$ & $\operatorname{LOD}\left(\mathrm{ngL}^{-1}\right)$ & $\begin{array}{l}\text { Concentration } \\
\quad \text { reported }\left(\mathrm{ngL}^{-1}\right)\end{array}$ & Ref. & Taxon & Species & $\begin{array}{l}\text { Toxicological } \\
\text { endpoint }\end{array}$ & $\begin{array}{l}\text { Ecotoxicity } \\
\text { data }\end{array}$ & Ref. \\
\hline Diatrizoate & $131-49-7$ & $\begin{array}{l}\text { STPeffluent } \\
\text { Surface water } \\
\text { Groundwater }\end{array}$ & Germany & SPE-LC-MS/MS & $\begin{array}{l}50 \text { (LOQSTP effluent) } \\
10 \text { (LOQ surface water; groundwater) }\end{array}$ & $\begin{array}{c}250 \\
<10-8700 \\
30\end{array}$ & [199] & & & & & \\
\hline Diatrizoate & & $\begin{array}{l}\text { Surface water } \\
\text { Drinking water }\end{array}$ & Germany & SPE-HPLC-MS & $-t$ & $\begin{array}{l}2000 \\
1200\end{array}$ & [203] & & & & & \\
\hline Diatrizoate & & $\begin{array}{l}\text { STP effluent } \\
\text { Rhine river } \\
\text { water } \\
\text { Drinking water }\end{array}$ & Germany & SPE-LC-MS/MS & $\begin{array}{l}50 \text { (LOQSTP effluenT) } \\
10 \text { (LOQ surface and drinking water) }\end{array}$ & $\begin{array}{c}1140 \\
110-140 \\
60\end{array}$ & [204] & & & & & \\
\hline Iohexol & $66108-95-0$ & $\begin{array}{l}\text { STP influent } \\
\text { STPeffluent }\end{array}$ & Australia & DI-LC-MS/MS & 800 & $\begin{array}{l}2800-4760 \\
<800\end{array}$ & [201] & & & & & \\
\hline Iohexol & & $\begin{array}{l}\text { Danube river } \\
\text { water }\end{array}$ & Germany & $\begin{array}{l}\text { SPE-HPLC- } \\
\text { MS/MS }\end{array}$ & 40 & $40-86$ & [202] & & & & & \\
\hline Iomeprol & $78649-41-9$ & $\begin{array}{l}\text { STP effluent } \\
\text { Surface water }\end{array}$ & Germany & SPE-LC-MS/MS & $\begin{array}{l}50 \text { (LOQSTP effluent) } \\
10 \text { (LOQ surface water) }\end{array}$ & $\begin{array}{l}370 \\
10-890\end{array}$ & [199] & & & & & \\
\hline Iomeprol & & $\begin{array}{l}\text { STPinfluent } \\
\text { STPeffluent }\end{array}$ & Australia & DI-LC-MS/MS & 730 & $\begin{array}{l}<730 \\
<730\end{array}$ & [201] & & & & & \\
\hline Iomeprol & & $\begin{array}{l}\text { Danube river } \\
\text { water }\end{array}$ & Germany & $\begin{array}{l}\text { SPE-HPLC- } \\
\text { MS/MS }\end{array}$ & 40 & $100-160$ & [202] & & & & & \\
\hline Iopamidol & 60166-93-0 & Groundwater & Germany & $\begin{array}{l}\text { SPE- } \\
\text { HPLC-MS/MS }\end{array}$ & 14 & 300 & [26] & & & & & \\
\hline Iopamidol & & $\begin{array}{l}\text { STPeffluent } \\
\text { Surface water } \\
\text { Groundwater }\end{array}$ & Germany & SPE-LC-MS/MS & $\begin{array}{l}50 \text { (LOQSTP effluent) } \\
10 \text { (LOQ surface water; groundwater) }\end{array}$ & $\begin{array}{c}660 \\
170-2800 \\
160\end{array}$ & [199] & & & & & \\
\hline Iopamidol & & $\begin{array}{l}\text { STPinfluent } \\
\text { STPeffluent }\end{array}$ & Australia & DI-LC-MS/MS & 220 & $\begin{array}{l}400-620 \\
<220\end{array}$ & [201] & & & & & \\
\hline Iopamidol & & $\begin{array}{l}\text { Danube river } \\
\text { water }\end{array}$ & Germany & $\begin{array}{l}\text { SPE-HPLC- } \\
\text { MS/MS }\end{array}$ & 40 & 210 & [202] & & & & & \\
\hline Iopamidol & & $\begin{array}{l}\text { STP effluent } \\
\text { Rhine river } \\
\text { water } \\
\text { Drinking water }\end{array}$ & Germany & SPE-LC-MS/MS & $\begin{array}{l}50 \text { (LOQSTP effluent) } \\
10 \text { (LOQ surface and drinking water) }\end{array}$ & $\begin{array}{c}590 \\
180-300 \\
70\end{array}$ & [204] & & & & & \\
\hline Iopromide & 73334-07-3 & $\begin{array}{l}\text { Drinking water } \\
\text { STP effluent }\end{array}$ & South Korea SPI & E-LC-MS/MS & 1.0 & $\begin{array}{l}70 \\
1170-4030\end{array}$ & [90] & Crustacean & D. magna & $\begin{array}{l}\mathrm{EC}_{50}(48 \mathrm{~h}) \\
\quad \text { (immobilization) }\end{array}$ & $>1 \mathrm{gL}^{-1}$ & {$[15] 7$} \\
\hline & & $\begin{array}{l}\text { Surface water } \\
\text { Drinking water }\end{array}$ & & & & $\begin{array}{l}20-361 \\
<1.0\end{array}$ & & & & & & \\
\hline Iopromide & & STPinfluent & Spain & SPE-LC-MS/MS & 6.7 & 6600 & [198] & Fish & D. rerio & $\begin{array}{l}\text { NOEC(28d) } \\
\text { (hatchability, } \\
\text { post-hatch survival, } \\
\text { body length, weight) }\end{array}$ & $>100 \mathrm{mg} \mathrm{L}^{-1}$ & {$[157]$} \\
\hline Iopromide & & $\begin{array}{l}\text { STPeffluent } \\
\text { STP effluent }\end{array}$ & Germany & SPE-LC-MS/MS & 50 (LOQSTP effluent) & $\begin{array}{l}9300 \\
4400\end{array}$ & [199] & Bacteria & V. fischeri & $\begin{array}{l}\mathrm{EC}_{50}(30 \mathrm{~min}) \\
\quad \text { (luminescence) }\end{array}$ & $>10.0 \mathrm{gL}^{-1}$ & [158] \\
\hline & & $\begin{array}{l}\text { Surface water } \\
\text { Groundwater }\end{array}$ & & & 10 (LOQ surface water; groundwater) & $\begin{array}{c}11-910 \\
<10\end{array}$ & & & & & & \\
\hline Iopromide & & STPinfluent & USA & SPE-LC-MS/MS & 0.577 & ND-17 & [200] & & P. putida & $\begin{array}{l}\mathrm{EC}_{10}(16 \mathrm{~h}) \text { (growth } \\
\text { inhibition) }\end{array}$ & $>10.0 \mathrm{gL}^{-1}$ & [158] \\
\hline & & STP effluent & & & & 4.6 & & & & & & \\
\hline & & $\begin{array}{l}\text { Ohioriver } \\
\text { water }\end{array}$ & & & & 2.2 & & & & & & \\
\hline & & Drinking water & & & & 4.6 & & & & & & \\
\hline
\end{tabular}




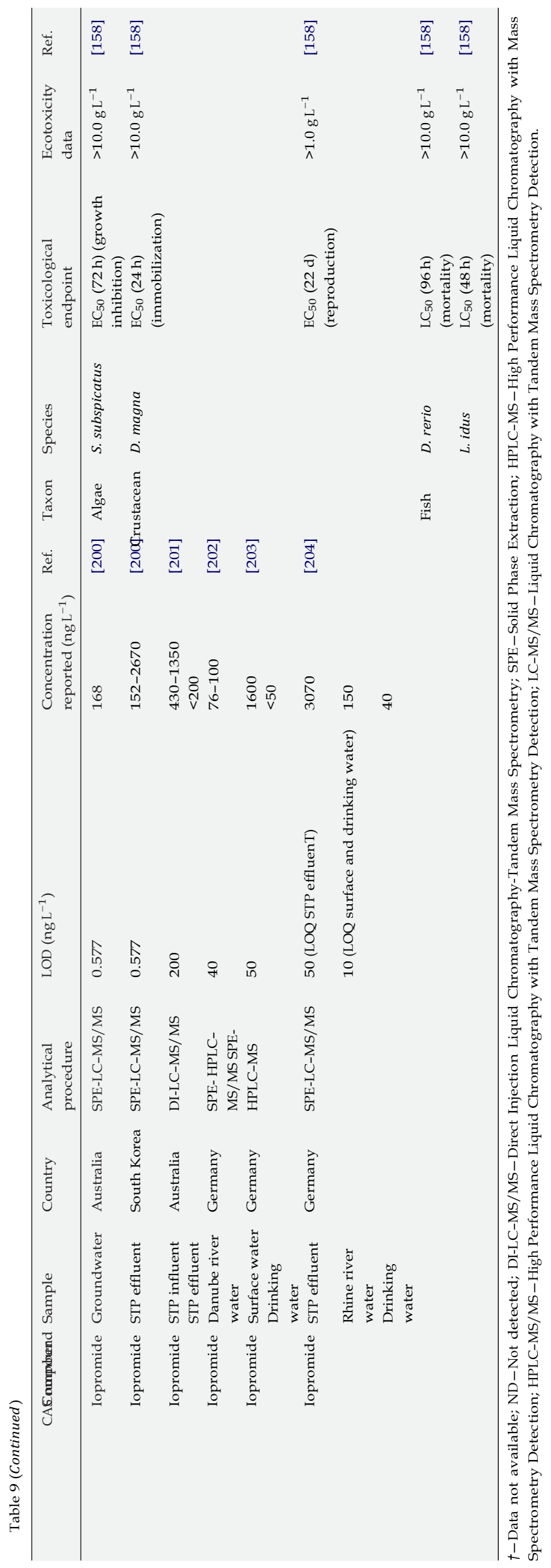

only require Phase II studies if the predicted environmental con- centration in surface water is equal to or above $0.01 \mu \mathrm{g} \mathrm{L}^{-1}$ [213].

In the US, issues concerning pharmaceuticals in the environ- ment are regulated by the U.S. Food and Drug Administration (FDA). This institution requires environmental assessments to obtain mar- keting authorisations which are specified in the "Guidance for Industry-Environmental Assessment of Human Drug and Biologic Applications" [214]. However, an environmental assessment is required only if the estimated environmental concentration of the pharmaceutical at the point of the entry is above $1 \mu \mathrm{g} \mathrm{L}^{-1}$ [214]. As EMEA, the FDA also requires environmental assessments for vet- erinary medicinal products, using a tiered approach. With a view to harmonising the guidelines that govern these environmental impact assessments, the EU, US and Japan elaborated two guide- lines: "Environmental Impact Assessment (EIAs) for Veterinary Medicinal Products (VMPs)—Phase I" [215] and "Environmental Impact Assessment for Veterinary Medicinal ProductsPhase II Guidance" [216] so that environmental fate and toxicity data obtained could be used to obtain marketing authorisation in all these regions.

\section{Conclusions}

Today, the presence of pharmaceuticals in the environment is being reported worldwide. Furthermore, new data on the sources, fate and effects of pharmaceuticals in the environment, seems to indicate the possibility of a negative impact on different ecosys- tems and imply a threat to public health. For this assumption, data from acute and chronic ecotoxicity tests on species belong- ing to different trophic levels such as bacteria, algae, crustaceans and fish among others, is relevant to illustrate the several adverse effects that environmental exposure to measured concentrations of these contaminants can have. On literature, the principal toxico- logical endpoints/studies that are described are growth, survival, reproduction and immobilization of species, comparatively to transgenerational and population level studies that are still sparse. This demonstrates the lack of data relatively to long-term expo- sure of non-target organisms and principally how a continuous exposure, during several generations, may affect a whole popu- lation. To our knowledge, just one work followed the impact of a pharmaceutical in a fish population throughout seven years, showing how ethinylestradiol negatively affect the fish popula- tion, leaving them near of the extinction. In the near future, the evaluation of chronic toxicity effects should be set out as a prior- ity for the scientific community since simultaneous exposure to pharmaceuticals, metabolites and transformation products of sev- eral therapeutic classes are unknown and whose probable effects on subsequent generations should be assumed. Another example of missing data is what occurs with statins. Nowadays, they are the blood lipid lowering agents most used all over the world, although toxicity data relatively to them is almost non-existent and lim- ited to the active substances simvastatin and atorvastatin. It is also important to assess the presence of pharmaceuticals and/or their metabolites and transformation products in several environmental compartments in different countries with a view to gaining reliable knowledge of the contamination levels. Only with further available information will be easier to improve existing legislation in order to protect humans, animals and ecosystems from the threat posed by the presence of pharmaceuticals in the environment.

\section{Acknowledgements}

Lúcia H.M.L.M. Santos thanks to FCT the $\mathrm{PhD}$ grant (SFRH/BD/48168/2008). 


\section{References}

[1] A.W. Garrison, J.D. Pope, F.R. Allen, GC/MS analysis of organic compounds in domestic wastewaters, in: C.H. Keith (Ed.), Identification and Analysis of Organic Pollutants in Water, Ann Arbor Science Publishers, Ann Arbor, MI, 1976, pp. 517-556.

[2] C. Hignite, D.L. Azarnoff, Drugs and drugs metabolites as environmental contaminants: chlorophenoxyisobutyrate and salicylic acid in sewage water effluent, Life Sci. 20 (1977) 337-341.

[3] M.L. Richardson, J.M. Bowron, The fate of pharmaceutical chemicals in the aquatic environment, J. Pharm. Pharmacol. 37 (1985) 1-12.

[4] G.W. Aherne, J. English, V. Marks, The role of imunoassay in the analysis of microcontaminants in water samples, Ecotoxicol. Environ. Saf. 9 (1985) 79-83.

[5] G.W. Aherne, A. Hardcastle, A.H. Nield, Cytotoxic drugs and the aquatic environment: estimation of bleomycin in river and water samples, J. Pharm. Pharmacol. 42 (1990) 741-742.

[6] K. Kümmerer, Introduction: pharmaceuticals in the environment, in: K. Küm- merer (Ed.), Pharmaceuticals in the Environment: Sources, Fate, Effects and Risks, Springer, Berlin, 2001, pp. 1-8.

[7] P. Pfluger, D.R. Dietrich, Effects on pharmaceuticals in the environment-an overview and principle considerations, in: K. Kümmerer (Ed.), Pharmaceu- ticals in the Environment: Sources, Fate, Effects and Risks, Springer, Berlin, 2001, pp. $11-17$

[8] E. Zuccato, S. Castiglioni, R. Fanelli, G. Reitano, R. Bagnati, C. Chiabrando, F. Pomati, C. Rossetti, D. Calamari, Pharmaceuticals in the environment in Italy: causes, occurrence, effects and control, Environ. Sci. Pollut. Res. 13 (2006) 1521.

[9] S.T. Glassmeyer, E.H. Hinchey, S.E. Boehme, C.G. Daughton, I.S. Ruhoy, O Conerly, R.L. Daniels, L. Lauer, M. McCarthy, T.G. Nettesheim, K. Sykes, V.G. Thompson, Disposal practises for unwanted residential medications in the United States, Environ. Int. 35 (2009) 566-572.

[10] K. Fent, A.A. Weston, D. Caminada, Ecotoxicology of human pharmaceuticals, Aquat. Toxicol. 76 (2006) 122-159.

[11] B. Halling-Sørensen, S. Nors Nielsen, P.F. Lanzky, F. Ingerslev, H.C. Holten Lützhøft, S.E. Jørgensen, Occurrence, fate and effects of pharmaceutical substances in the environment - a review, Chemosphere 36 (1998) 357-393.

[12] J.L.C.M. Dorne, A.M.J. Ragas, G.K. Frampton, D.S. Spurgeon, D.F. Lewis, Trends in human risk assessment of pharmaceuticals, Anal. Bioanal. Chem. 387 (2007) $1167-1172$

[13] S.T. Glassmeyer, D.W. Kolpin, E.T. Furlong, M.J. Focazio, Environmental pres- ence and persistence of pharmaceuticals: an overview, in: D.S. Aga (Ed.), Fate of Pharmaceuticals in the Environment and in Water Treatment Systems, CRC Press, Taylor and Francis, 2008, pp. 3-52.

[14] M.J. Gómez, M.J. Martínez Bueno, S. Lacorte, A.R. Fernández-Alba, A. Agüera, Pilot survey monitoring pharmaceuticals and related compounds in a sewage treatment plant located on the Mediterranean coast, Chemosphere 66 (2007) 993-1002.

[15] A. Tauxe-Wuersch, L.F. De Alencastro, D. Grandjean, J. Tarradellas, Occurrence of several acidic drugs in sewage treatment plants in Switzerland and risk assessment, Water Res. 39 (2005) 1761-1772.

[16] N.M. Vieno, T. Tuhkanen, L. Kronberg, Analysis of neutral and basic pharmaceuticals in sewage treatment plants and in recipient rivers using solid phase extraction and liquid chromatography-tandem mass spectrometry detection, J. Chromatogr. A 1134 (2006) 101-111.

[17] S.S. Verenitch, C.J. Lowe, A. Mazumder, Determination of acidic drugs and caffeine in municipal wastewaters and receiving waters by gas chromatography-ion trap tandem mass spectrometry, J. Chromatogr. A 1116 (2006) 193-203.

[18] H.-B. Lee, T.E. Peart, M.L. Svoboda, Determination of endocrine-disrupting phenols, acidic pharmaceuticals, and personal-care products in sewage by solidphase extraction and gas chromatography-mass spectrometry, J. Chro- matogr. A 1094 (2005) 122-129.

[19] V. Koutsouba, Th. Heberer, B. Fuhrmann, K. Schmidt-Baumler, D. Tsipi, A. Hiskia, Determination of polar pharmaceuticals in sewage water of Greece by gas chromatography-mass spectrometry, Chemosphere 51 (2003) 69-75.

[20] Z. Moldovan, Occurrences of pharmaceutical and personal care products as micropollutants in rivers from Romania, Chemosphere 64 (2006) 1808-1817.

[21] D. Bendz, N.A. Paxéus, T.R. Ginn, F.J. Loge, Occurrence and fate of pharmaceutically active compounds in the environment, a case study: Höje River in Sweden, J. Hazard. Mater. 122 (2005) 195-204.

[22] M. Stumpf, T.A. Ternes, R.-D. Wilken, S.V. Rodrigues, W. Baumann, Polar drug residue in sewage and natural waters in the state of Rio de Janeiro, Brazil, Sci. Total Environ. 225 (1999) 135-141

[23] D.W. Kolpin, E.T. Furlong, M.T. Meyer, E.M. Thurman, S.D. Zaugg, L.B. Barber, H.T. Buxton, Pharmaceuticals, hormones, and other organic wastewater contaminants in U.S. streams, 1999-2000: a national reconnaissance, Environ. Sci. Technol. 36 (2002) 1202-1211.

[24] D. Calamari, E. Zuccato, S. Castiglioni, R. Bagnati, R. Fanelli, Strategic survey of therapeutic drugs in the Rivers Po and Lambro in Northern Italy, Environ. Sci. Technol. 37 (2003) 1241-1248.

[25] S. Weigel, J. Kuhlmann, H. Hühnerfuss, Drugs and personal care products as ubiquitious pollutants: occurrence and distribution of clofibric acid, caffeine and DEET in the North Sea, Sci. Total Environ. 295 (2002) 131-141.

[26] F. Sacher, F.T. Lange, H.-J. Brauch, I. Blankenhorn, Pharmaceuticals in groundwaters. Analytical methods and results of a monitoring pro- gram in Baden-Württemberg, Germany, J. Chromatogr. A 938 (2001) 199-210.

[27] A.L. Batt, D.D. Snow, D.S. Aga, Occurrence of sulfonamide antimicrobials in pri- vate water wells in Washington County, Idaho, USA, Chemosphere 64 (2006) 1963 1971.

[28] K.K. Barnes, D.W. Kolpin, E.T. Furlong, S.D. Zaugg, M.T. Meyer, L.B. Barber, A national reconnaissance of pharmaceuticals and other organic wastewater contaminants in the United States-I) Groundwater, Sci. Total Environ. 402 (2008) 192-200.

[29] C. Potera, Drugged drinking water, Environ. Health Perspect. 108 (2000) A446-A449.

[30] R. Loos, J. Wollgast, T. Huber, G. Hanke, Polar herbicides, pharmaceutical products, perfluorooctanesulfonate (PFOS), perfluorooctanoate (PFOA), and nonylphenol and its carboxylates and ethoxylates in surface and tap waters around Lake Maggiore in Northern Italy, Anal. Bioanal. Chem. 387 (2007) 1469-1478.

[31] M.J. Focazio, D.W. Kolpin, K.K. Barnes, E.T. Furlong, M.T. Meyer, S.D. Zaugg, L.B. Barber, M.E. Thurman, A national reconnaissance for phar- maceuticals and other organic wastewater contaminants in the United States-II) Untreated drinking water sources, Sci. Total Environ. 402 (2008) 201-216.

[32] M.J.Benotti, R.A.Trenholm, B.J.Vanderford, J.C. Holady, B.D. Stanford, S.A. Sny- der, Pharmaceuticals and endocrine disrupting compounds in U.S. drinking water, Environ. Sci. Technol. 43 (2009) 597-603.

[33] A.R.R. Péry, M. Gust, B. Vollat, R. Mons, M. Ramil, G. Fink, T. Ternes, J. Gar- ric, Fluoxetine effects assessment on the life cycle of aquatic invertebrates, Chemosphere 73 (2008) 300-304.

[34] K.A. Kidd, P.J. Blanchfield, K.H. Mills, V.P. Palace, R.E. Evans, J.M. Lazorchak, R.W. Flick, Collapse of a fish population after exposure to a synthetic estrogen, Proc. Natl. Acad. Sci. U.S.A. 104 (2007) 8897-8901.

[35] C.G. Daughton, T.A. Ternes, Pharmaceuticals and personal care products in the environment: agents of subtle changes? Environ. Health Perspect. 107 (1999) 907 938.

[36] J. Timbrell, Principles of Biochemical Toxicology, third ed., Taylor \& Francis, London, 2002.

[37] R. Braund, B.M. Peake, L. Schieffelbien, Disposal practises for unused medica- tions in New Zeland, Environ. Int. 35 (2009) 952-955.

[38] M. Persson, E. Sabelström, B. Gunnarsson, Handling of unused prescriptiondrugsknowledge, behaviour and attitude among Swedish people, Environ. Int. 35 (2009) 771-774.

[39] T. Heberer, Occurrence, fate, and removal of pharmaceutical residues in the aquatic environment: a review of recent research data, Toxicol. Lett. 131 (2002) 5-17.

[40] J.P. Bound, N. Voulvoulis, Household disposal of pharmaceuticals as a pathway for aquatic contamination in the United Kingdom, Environ. Health Perspect. 113 (2005) $1705-1711$.

[41] K. Xia, A. Bhandari, K. Das, G. Pillar, Occurrence and fate of pharmaceuticals and personal care products (PPCPs) in biosolids, J. Environ. Qual. 34 (2005) 91-104.

[42] E. Topp, S.C. Monteiro, A. Beck, B.B. Coelho, A.B.A. Boxall, P.W. Duenk, S. Kleywegt, D.R. Lapen, M. Payne, L. Sabourin, H. Li, C.D. Metcalfe, Runoff of pharmaceuticals and personal care products following applica- tion of biosolids to an agricultural field, Sci. Total Environ. 396 (2008) 52-59.

[43] N. Kemper, Veterinary antibiotics in the aquatic and terrestrial environment, Ecol. Indic. 8 (2008) 1-13.

[44] P. Kay, P.A. Blackwell, A.B.A. Boxall, Transport of veterinary antibiotics in over- land flow following the application of slurry to arable land, Chemosphere 59 (2005) 951-959.

[45] T.X. Le, Y. Munekage, Residues of selected antibiotics in water and mud from shrimp ponds in mangrove areas in Viet Nam, Marine Pollut. Bull. 49 (2004) 922 929.

[46] G.M. Lalumera, D. Calamari, P. Galli, S. Castiglioni, G. Crosa, R. Fanelli, Prelimi- nary investigation on the environmental occurrence and effects of antibiotics used in aquaculture in Italy, Chemosphere 54 (2004) 661-668.

[47] A.Y.-C. Lin, Y.-T. Tsai, Occurrence of pharmaceuticals in Taiwan's surface waters: impact of waste streams from hospitals and pharmaceutical produc- tion facilities, Sci. Total Environ. 407 (2009) 3793-3802.

[48] D. Li, M. Yang, J. Hu, Y. Zhang, H. Chang, F. Jin, Determination of penicillin G and its degradation products in a penicillin production wastewater treatment plant and the receiving river, Water Res. 42 (2008) 307-317.

[49] D.G.J. Larsson, C. Pedro, N. Paxeus, Effluent from drug manufactures con- tains extremely high levels of pharmaceuticals, J. Hazard. Mater. 148 (2007) 751-755.

[50] A.L. Boreen, W.A. Arnold, K. McNeill, Photodegradation of pharmaceuticals in the aquatic environment: a review, Aquat. Sci. 65 (2003) 320-341.

[51] P. Bartels, W. Tümpling Jr., Solar radiation influence on the decomposi- tion process of diclofenac in surface waters, Sci. Total Environ. 374 (2007) 143-155.

[52] M. Crane, C. Watts, T. Boucard, Chronic aquatic environmental risks from exposure to human pharmaceuticals, Sci. Total Environ. 367 (2006) 23-41.

[53] P.H. Roberts, K.V. Thomas, The occurrence of selected pharmaceuticals in wastewater effluent and surface waters of the lower Tyne catchment, Sci. Total Environ. 356 (2006) 143-153.

[54] T.A. Ternes, Occurrence of drugs in German sewage treatment plants and rivers, Water Res. 32 (1998) 3245-3260. 
[55] N. Lindqvist, T. Tuhkanen, L. Kronberg, Occurrence of acidic pharmaceuticals in raw and treated sewages and in receiving waters, Water Res. 39 (2005) 2219-2228.

[56] D.L. Sedlak, K.E. Pinkston, Factors affecting the concentrations of pharmaceu- ticals released to the aquatic environment, Water Resour. Update 120 (2001) 56-64.

[57] M. Cirja, P. Ivashechkin, A. Schäffer, P.F.X. Corvini, Factors affecting the removal of organic micropollutants from wastewater in conventional treat- ment plants (CTP) and membrane bioreactors (MBR), Rev. Environ. Sci. Biotechnol. 7 (2008) 61-78.

[58] K. Kümmerer, Drugs in the environment: emission of drugs, diagnostic aids and disinfectants into wastewater by hospitals in relation to other sources - a review, Chemosphere 45 (2001) 957-969.

[59] A.Y.-C. Lin, T.-H. Yu, C.-F. Lin, Pharmaceutical contamination in residential, industrial, and agricultural waste streams: risk to aqueous environments in Taiwan, Chemosphere 74 (2008) 131-141.

[60] C. Zwiener, T.J. Gremm, F.H. Frimmel, Pharmaceutical residues in the aquatic environment and their significance for drinking water production, in: K. Küm- merer (Ed.), Pharmaceuticals in the Environment: Sources, Fate, Effects and Risks, Springer, Berlin, 2001, pp. 81-89.

[61] P.E. Stackelberg, E.T. Furlong, M.T. Meyer, S.D. Zaugg, A.K. Henderson, D.B. Reissman, Persistence of pharmaceutical compounds and other organic wastewater contaminants in a conventional drinking-water-treatment plant, Sci. Total Environ. 329 (2004) $99-113$.

[62] J.R. Vane, R.M. Botting, Mechanism of action of antiinflammatory drugs, Int. J. Tissue React. 20 (1998) 3-15

[63] J. Zou, N.F. Neumann, J.W. Holland, M. Belosevic, C. Cunningham, C.J. Secombes, A.F. Rowley, Fish macrophages express a cyclo-oxygenase-2 homologue after activation, Biochem. J. 340 (1999) 153-159.

[64] C.E. Lundholm, DDE-induced eggshell thinning in birds: effects of p,p'-DDE on the calcium and prostaglandin metabolism of the eggshell gland, Comp. Biol. Physiol. $118 \mathrm{C}$ (1997) 113-128.

[65] M. Cleuvers, Aquatic ecotoxicity of pharmaceuticals including the assessment of combination effects, Toxicol. Lett. 142 (2003) 185-194.

[66] J. Schwaiger, H. Ferling, U. Mallow, H. Wintermayr, R.D. Negele, Toxic effects of the non-steroidal anti-inflammatory drug diclofenac. Part I: histopathological alterations and bioaccumulation in rainbow trout, Aquat. Toxicol. 68 (2004) 141-150.

[67] R. Triebskorn, H. Casper, A. Heyd, R. Eikemper, H.-R. Köhler, J. Schwaiger, Toxic effects of the non-steroidal anti-inflammatory drug diclofenac. Part

II. Cytological effects in liver, kidney, gills and intestine of rainbow trout (Oncorhynchus mykiss), Aquat. Toxicol. 68 (2004) 151-166.

[68] B. Hoeger, B. Köllner, D.R. Dietrich, B. Hitzfeld, Water-borne diclofenac affects kidney and gill integrity and selected immune parameters in brown trout (Salmo trutta f. fario), Aquat. Toxicol. 75 (2005) 53-64.

[69] M. Schmitt-Jansen, P. Bartels, N. Adler, R. Altenburger, Phytotoxicity assess- ment of diclofenac and its phototransformation products, Anal. Bioanal. Chem. 387 (2007) 1389-1396

[70] M.E. DeLorenzo, J. Fleming, Individual and mixture effects of selected pharmaceuticals and personal care products on the marine phytoplank-ton species Dunaliella tertiolecta, Arch. Environ. Contam. Toxicol. 54 (2008) 203-210.

[71] M.D. Hernando, E. Heath, M. Petrovic, D. Barceló, Trace-level determination of pharmaceuticals residues by LC-MS/MS in natural and treated waters. A pilotsurvey study, Anal. Bioanal. Chem. 385 (2006) 985-991.

[72] S. Weigel, R. Kallenborn, H. Hühnerfuss, Simultaneous solid-phase extrac- tion of acidic, neutral and basic pharmaceuticals from aqueous samples at ambient (neutral) $\mathrm{pH}$ and their determination by gas chromatography-mass spectrometry, $\mathrm{J}$. Chromatogr. A 1023 (2004) 183-195.

[73] M.J. Gómez, M. Petrovic' , A.R. Fernández-Alba, D. Barceló, Determination of pharmaceuticals of various therapeutic classes by solid-phase extraction and liquid chromatography-tandem mass spectrometry analysis in hospital efflu- ent wastewaters, J. Chromatogr. A 1114 (2006) 224-233.

[74] J.L. Flippin, D. Huggett, C.M. Foran, Changes in the timing of reproduction following chronic exposure to ibuprofen in Japanese medaka, Oryzias latipes, Aquat. Toxicol. 81 (2007) 73-78.

[75] L.-H. Heckamann, A. Callaghan, H.L. Hooper, R. Connon, T.H. Hutchinson, S.J. Maund, R.M. Sibly, Chronic toxicity of ibuprofen to Daphnia magna: effects on life history traits and population dynamics, Toxicol. Lett. 172 (2007) 137-145.

[76] H.J. De Lange, W. Noordoven, A.J. Murk, M. Lürling, E.T.H.M. Peeters, Behavioural responses of Gammarus pulex (Crustacea, Amphipoda) to low concentrations of pharmaceuticals, Aquat. Toxicol. 78 (2006) 209-216.

[77] F. Pomati, A.G. Netting, D. Calamari, B.A. Neilan, Effects of erythromycin, tetraycline and ibuprofen on the growth of Synechocystis sp. and Lemna minor, Aquat. Toxicol. 67 (2004) 387-396.

[78] J.-W. Kim, H. Ishibashi, R. Yamauchi, N. Ichikawa, Y. Takao, M. Hirano, M. Koga, $\mathrm{K}$. Arizono, Acute toxicity of pharmaceutical and personal care products on freshwater crustacean (Thamnocephalus platyurus) and fish (Oryzias latipes), J. Toxicol. Sci. 34 (2009) 227-232.

[79] N. Pounds, S. Maclean, M. Webley, D. Pascoe, T. Hutchinson, Acute and chronic effects of ibuprofen in the mollusc Planorbis carinatus (Gastropoda: Planorbidae), Ecotoxicol. Environ. Saf. 70 (2008) 47-52.

[80] M. Isidori, M. Lavorgna, A. Nardelli, A. Parrella, L. Previtera, M. Rubino, Ecotoxicity of naproxen and its phototransformation products, Sci. Total Environ. 348 (2005) 93-101.
[81] P.M. Thomas, G.D. Foster, Determination of nonsteroidal anti-inflammatory drugs, caffeine, and triclosan in wastewater by gas chromatography-mass spectrometry, $\mathbf{J}$ Environ. Sci. Health. Part A Toxic/Hazard. Subst. Environ. Eng. A39 (2004) 1969 1978.

[82] Y. Kim, K. Choi, J. Jung, S. Park, P.-G. Kim, J. Park, Aquatic toxicity of acetaminophen, carbamazepine, cimetidine, diltiazem and six major sulfonamides, and their potential ecological risks in Korea, Environ. Int. 33 (2007) 275370.

[83] K.-P. Henschel, A. Wenzel, M. Diedrich, A. Fliedner, Environmental hazard assessment of pharmaceuticals, Regul. Toxicol. Pharm. 25 (1997) 220-225.

[84] S. Grujic', T. Vasiljevic', M. Laus`evic', Determination of multiple pharmaceu- tical classes in surface and ground waters by liquid chromatography-ion trap-tandem mass spectrometry, J. Chromatogr. A 1216 (2009) 4989-5000.

[85] C. Carlsson, A.-K. Johansson, G. Alvan, K. Bergman, T. Kühler, Are pharmaceuti- cals potent environmental pollutants? Part I: environmental risk assessments of selected active pharmaceutical ingredients, Sci. Total Environ. 364 (2006) 67-87.

[86] N. Nakada, T. Tanishima, H. Shinohara, K. Kiri, H. Takada, Pharmaceuti- cal chemicals and endocrine disrupters in municipal wastewater in Tokyo and their removal during activated sludge treatment, Water Res. 40 (2006) 3297-3303.

[87] A.Y.-C. Lin, T.-H. Yu, S.K. Lateef, Removal of pharmaceuticals in sec- ondary wastewater treatment processes in Taiwan, J. Hazard. Mater. (2009), doi:10.1016/j.Jhazmat.2009.01.108

[88] J.-L. Zhao, G.-G. Ying, L. Wang, J.-F. Yang, X.-B. Yang, L.-H. Yang, X. Li, Determination of phenolic endocrine disrupting chemicals and acidic phar maceuticals in surface water of the Pearl Rivers in South China by gas chromatography-negative chemical ionization-mass spectrometry, Sci. Total Environ. 407 (2009) 962-974.

[89] J.-Y. Pailler, K.L. Pfister, L. Hoffmann, C. Guignard, Solid phase extraction coupled to liquid chromatography-tandem mass spectrometry analysis of sulfonamides, tetracyclines, analgesics and hormones in surface water and wastewater in Luxembourg, Sci. Total Environ. 407 (2009) 4736-4743.

[90] S.D. Kim, J. Cho, I.S. Kim, B.J. Vanderford, S.A. Snyder, Water Res. 41 (2007) $1013-1021$.

[91] M.J.M. Bueno, A. Agüera, M.D. Hernando, M.J. Gómez, A.R. Fernández-Alba, Evaluation of various liquid chromatography-quadrupole-linear ion trap- mas spectrometry operation modes applied to the analysis of organic pollutants in wastewaters, J. Chromatogr. A 1216 (2009) 5995-6002.

[92] J.-W. Kim, H.-S. Jang, J.-G. Kim, H. Ishibashi, M. Hirano, K. Nasu, N. Ichikawa, Y. Takao, R. Shinohara, K. Arizono, Occurrence of pharmaceutical and personal care products (PPCPs) in surface water from Mankyung River, South Korea, J. Health Sci 55 (2009) 249-258

[93] K. Choi, Y. Kim, J. Park, C.K. Park, M. Kim, H.S. Kim, P. Kim, Seasonal variations of several pharmaceutical residues in surface water and sewage treatment plants of Han River, Korea, Sci. Total Environ. 405 (2008) 120-128.

[94] M.J. Hilton, K.V. Thomas, Determination of selected human pharmaceutical compounds in effluent and surface water samples by high-performance liquid chromatography-electrospray tandem mass spectrometry, J. Chromatogr. A 1015 (2003) 129-141.

[95] M. Cleuvers, Mixture toxicity of anti-inflammatory drugs diclofenac, ibupro- fen, naproxen, and acetylsalicylic acid, Ecotoxicol. Environ. Saf. 59 (2004) 309-315.

[96] B. Ferrari, N. Paxéus, R.L. Giudice, A. Pollio, J. Garric, Ecotoxicological impact of pharmaceuticals found in treated wastewaters: study of carba- mazepine, clofibric acid, and diclofenac, Ecotoxicol. Environ. Saf. 55 (2003) 359-370.

[97] R. Triebskorn, H. Casper, V. Scheil, J. Schwaiger, Ultrastructural effects of pharmaceuticals (carbamazepine, clofibric acid, metoprolol, diclofenac) in rainbow trout (Oncorhynchus mykiss) and common carp (Cyprinus carpio), Anal Bioanal. Chem. 387 (2007) 1405-1416.

[98] B. Quinn, F. Gagné, C. Blaise, An investigation into the acute and chronic toxicity of eleven pharmaceuticals (and their solvents) found in wastewa- ter effluent on the cnidarian, Hydra attenuate, Sci. Total Environ. 389 (2008) 306-314.

[99] H.P. Rang, M.M. Dale, J.M. Ritter, Pharmacology, fourth ed., Churchill Living- stone, Edinburgh, 1999.

[100] C.A. Aguilar-Salinas, H. Barrett, G. Schonfeld, Metabolic modes of action of the statins in the hyperlipoproteinemias, Atherosclerosis 141 (1998) 203-207.

[101] P.B. Key, J. Hoguet, L.A. Reed, K.W. Chung, M.H. Fulton, Effects of the statin antihyperlipidemic agent simvastatin on grass shrimp, Palaemonetes pugio, Environ. Toxicol. 23 (2008) 153-160

[102] U. Dahl, E. Gorokhova, M. Breitholtz, Application of growth-related subletha endpoints in ecotoxicological assessments using a harpacticoid copepod, Aquat. Toxicol. 77 (2006) 433-438.

[103] R.A. Brain, D.J. Johnson, S.M. Richards, M.L. Hanson, H. Sanderson, M.W. Lam, C. Young, S.A. Mabury, P.K. Sibley, K.R. Solomon, Microcosm evaluation of the effects of an eight pharmaceutical mixture to the aquatic macrophytes Lemna gibba and Myriophyllum sibiricum, Aquat. Toxicol. 70 (2004) 23-40.

[104] S. Debernard, F. Rossignol, F. Couillaud, The HMG-CoA reductase inhibito fluvastatin inhibits insect juvenile hormone biosynthesis, Gen. Comp. Endocrinol. 95 (1994) 92-98.

[105] X.-S. Miao, C.D. Metcalfe, Determination of cholesterol-lowering statin drugs in aqueous samples using liquid chromatography-electrospray ionization tandem mas spectrometry, J. Chromatogr. A 998 (2003) 133-141. 
[106] X.-S. Miao, C.D. Metcalfe, Determination of pharmaceuticals in aqueous samples using positive and negative voltage switching microbore liquid chromatography/electrospray ionization tandem mass spectrometry, J. Mass Spectrom. 38 (2003) 27-34.

[107] B. Staels, J. Dallongeville, J. Auwerx, K. Schoonjans, E. Leitersdorf, J.-C. Fruchart, Mechanism of action of fibrates on lipid and lipoprotein metabolism, Circu- lation 98 (1998) 2088-2093.

[108] H. Sanderson, R.A. Brain, D.J. Johnson, C.J. Wilson, K.R. Solomon, Toxicity classification and evaluation of four pharmaceuticals classes: antibiotics, antineoplastics, cardiovascular, and sex hormones, Toxicology 203 (2004) 27-40.

[109] A. Ibabe, A. Herrero, M.P. Cajaraville, Modulation of peroxisome proliferatoractivated receptors (PPARs) by PPAR $a$ - and PPAR)'-specific ligands and by 17 estradiol in isolated zebrafish hepatocytes, Toxicol. In Vitro 19 (2005) 725-735.

[110] D. Raldúa, M. André, P.J. Babin, Clofibrate and gemfibrozil induce an embry- onic malabsorption syndrome in zebrafish, Toxicol. Appl. Pharmacol. 228 (2008) 301-314.

[111] S.A. Kliewer, S.S. Sundseth, S.A. Jones, P.J. Brown, G.B. Wisely, C.S. Koble, P Devchand, W. Wahli, T.M. Willson, J.M. Lenhard, J.M. Lehmann, Fatty acids and eicosanoids regulate gene expression through direct interactions with peroxisome proliferation-activated receptors $a$ and )', Proc. Natl. Acad. Sci. U.S.A. 94 (1997) $4318-4323$.

[112] J.L. Zurita, G. Repetto, A. Jos, M. Salguero, M. López-Artígues, A.M. Cameán, Toxicological effects of the lipid regulator gemfibrozil in four aquatic systems, Aquat. Toxicol. 81 (2007) 106-115.

[113] M. Isidori, A. Nardelli, L. Pascarella, M. Rubino, A. Parrella, Toxic and genotoxic impact of fibrates and their photoproducts on non-target organism, Environ. Int. 33 (2007) 635-641.

[114] C. Mimeault, A.J. Woodhouse, X.-S. Miao, C.D. Metcalfe, T.W. Moon, V.L. Trudeau, The human lipid regulator, gemfibrozil bioconcentrates and reduces testosterone in the goldfish, Carassius auratus, Aquat. Toxicol. 73 (2005) 44-54.

[115] J.P. Emblidge, M.E. DeLorenzo, Preliminary risk assessment of the lipid- regulating pharmaceutical clofibric acid, for three estuarine species, Environ. Res. 100 (2006) 216-226.

[116] C.M. Flaherty, S.I. Dodson, Effects of pharmaceuticals on Daphnia survival, growth, and reproduction, Chemosphere 61 (2005) 200-207.

[117] T.J. Runnalls, D.N. Hala, J.P. Sumpter, Preliminary studies into the effects of the human pharmaceutical Clofibric acid on sperm parameters in adult Fathead minnow, Aquat. Toxicol. 84 (2007) 111-118

[118] S. Castiglioni, R. Bagnati, D. Calamari, R. Fanelli, E. Zuccato, A multiresidue analytical method using solid-phase extraction and high-pressure chro- matography tandem mass spectrometry to measure pharmaceuticals of different therapeutic classes in urban wastewaters, J. Chromatogr. A 1092 (2005) 206-215.

[119] K. Reddersen, T. Heberer, Multi-compound methods for the detection of pharmaceutical residues in various waters applying solid phase extraction (SPE) and gas chromatography with mass spectrometric (GC-MS) detection, J. Sep. Sci. 26 (2003) $1443-1450$

[120] O.A.H. Jones, N. Voulvoulis, J.N. Lester, Aquatic environmental assessment of the top 25 English prescription pharmaceuticals, Water Res. 36 (2002) 5013-5022.

[121] B. Halling-S $\varnothing$ rensen, Algal toxicity of antibacterial agents used in intensive farming, Chemosphere 40 (2000) 731-739.

[122] H.C. Holten Lützhøft, B. Halling-Sørensen, S.E. Jørgensen, Algal toxicity of antibacterial agents applied in Danish farming, Arch. Environ. Contam. Toxi- col. 36 (1999) 1-6.

[123] P.F. Lanzky, B. Halling-Sørensen, The toxic effect of the antibiotic metronida- zole on aquatic organisms, Chemosphere 35 (1997) 2553-2561.

[124] M. Isidori, M. Lavorgna, A. Nardelli, L. Pascarella, A. Parrella, Toxic and geno- toxic evaluation of six antibiotics on non-target organisms, Sci. Total Environ. 346 (2005) 87-98.

[125] T. Kümpel, R. Alexy, K. Kümmerer, What do we know about antibiotics in the environment? in: K. Kümmerer (Ed.), Pharmaceuticals in the Environment: Sources, Fate, Effects and Risks, Springer, Berlin, 2001, pp. 67-76.

[126] R. Andreozzi, V. Caprio, C. Ciniglia, M. De Champdoré, R. Lo Giudice, R. Marotta, E. Zuccato, Antibiotics in the environment: occurrence in Italian STPs, fate, and preliminary assessment on algal toxicity of amoxicillin Environ. Sci. Technol. 38 (2004) 6832-6838.

[127] X. Nie, J. Gu, J. Lu, W. Pan, Y. Yang, Effects of norfloxacin and butylated hydroxyanisole on the freshwater microalga Scenedesmus obliquus, Ecotoxicology 18 (2009) 677-684.

[128] A.B. Boxall, D.W. Kolpin, B. Halling-Sørensen, J. Tolls, Are veterinary medicines causing environmental risks? Environ. Sci. Technol. 37 (2003) 286A-294A.

[129] L. Migliore, C. Civitareale, S. Cozzolino, P. Casoria, G. Brambilla, L. Gaudio, Laboratory models to evaluate phytotoxicity of sulphadimethoxine on terrestrial plants, Chemosphere 37 (1998) 2957-2961.

[130] S.D. Costanzo, J. Murby, J. Bates, Ecosystem response to antibiotics entering the aquatic environment, Mar. Pollut. Bull. 51 (2005) 218-223.

[131] K. Eguchi, H. Nagase, M. Ozawa, Y.S. Endoh, K. Goto, K. Hirata, K. Miyamoto, H. Yoshimura, Evaluation of antimicrobial agents for veterinary use in the ecotoxicity test using microalgae, Chemosphere 57 (2004) $\quad 1733-1738$.

[132] N. Yamashita, M. Yasojima, K. Miyajima, Y. Suzuki, H. Tanaka, Effects of antibacterial agents, levofloxacin and clarithromycin, on aquatic organisms, Water Sci. Technol. 53 (2006) 65-72.
[133] J. Pro, J.A. Ortiz, S. Boleas, C. Fernández, G. Carbonell, J.V. Tarazona, Effect assessment of antimicrobial pharmaceuticals on the aquatic plant Lemna minor, Bull. Environ. Contam. Toxicol. 70 (2003) 290-295.

[134] L. Wollenberger, B. Halling-Sørensen, K.O. Kusk, Acute and chronic toxicity of veterinary antibiotics to Daphnia magna, Chemosphere 40 (2000) 723-730.

[135] M. De Liguoro, B. Fioretto, C. Poltronieri, G. Gallina, The toxicity of sulfamethazine to Daphnia magna and its additivity to other veterinary sulfonamides and trimethoprim, Chemosphere 75 (2009) 1519-1524.

[136] S. Park, K. Choi, Hazard assessment of commonly used agricultural antibiotics on aquatic ecosystems, Ecotoxicology 17 (2008) 526-538.

[137] S. Jiao, S. Zheng, D. Yin, L. Wang, L. Chen, Aqueous photolysis of tetracycline and toxicity of photolytic products to luminescent bacteria, Chemosphere 73 (2008) 377-382.

[138] K.D. Brown, J. Kulis, B. Thomson, T.H. Chapman, D.B. Mawhinney, Occurrence of antibiotics in hospital, residential, and dairy effluent, municipal wastew- ater, and the Rio Grande in New Mexico, Sci. Total Environ. 366 (2006) 772-783.

[139] M. Seifrtová, A. Pena, C.M. Lino, P. Solich, Determination of fluoroquinolone antibiotics in hospital and municipal wastewaters in Coimbra by liquid chromatography with a monolithic column and fluorescence detection, Anal Bioanal. Chem. 391 (2008) 799-805.

[140] K.G. Karthikeyan, M.T. Meyer, Occurrence of antibiotics in wastewa- ter treatment facilities in Wiscosin, USA, Sci. Total Environ. 361 (2006) 196-207.

[141] R.H. Lindberg, P. Wennberg, M.I. Johansson, M. Tysklind, B.A.V. Andersson, Screening of human antibiotic substances and determination of weekly mass flows in five sewage treatment plants in Sweden, Environ. Sci. Technol. 39 (2005) 3421-3429.

[142] A. Pena, D. Chmielova, C.M. Lino, P. Solich, Determination of fluorquinolone antibiotics in surface waters from Mondego River by high performance liquid chromatography using a monolithic column, J. Sep. Sci. 30 (2007) 2924-2928.

[143] D. Perret, A. Gentili, S. Marchese, A. Greco, R. Curini, Sulphonamide residues in Italian surface and drinking waters: a small scale reconnaissance, Chromatographia 63 (2006) 225-232.

[144] A. Gulkowska, Y. He, M.K. So, L.W.Y. Yeung, H.W. Leung, J.P. Giesy, P.K.S. Lam, M. Martin, B.J. Richardson, The occurrence of selected antibiotics in Hong Kong coastal waters, Mar. Pollut. Bull. 54 (2007) 1287-1306.

[145] W.-H. Xu, G. Zhang, S.-C. Zou, X.-D. Li, Y.-C. Liu, Determination of selected antibiotics in the Victoria Harbour and the Pearl River, South China using highperformance liquid chromatography-electrospray ionization tandem mass spectrometry, Environ. Pollut. 145 (2007) 672-679.

[146] D.G.J. Larsson, M. Adolfsson-Erici, J. Parkkonen, M. Pettersson, A.H. Berg, P.E. Olsson, L. Förlin, Ethinylestradiol - an undesired fish contraceptive? Aquat. Toxicol. 45 (1999) 91-97.

[147] S. Jobling, M. Nolan, C.R. Tyler, G. Brighty, J.P. Sumpter, Widespread sexual disruption in wild fish, Environ. Sci. Technol. 32 (1998) 2498-2506.

[148] J.L. Parrott, B.R. Blunt, Life-cycle exposure of fathead minnows (Pimephales promelas) to an ethinylestradiol concentration below $1 \mathrm{ng} / \mathrm{L}$ reduces egg fertilization success and desmasculinizes males, Environ. Toxicol. 20 (2005) 131141.

[149] S. Pawlowski, R. van Aerle, C.R. Tyler, T. Braunbeck, Effects of 17aethinylestradiol in a fathead minnow (Pimephales promelas) gonadal recrudescence assay, Ecotoxicol. Environ. Saf. 57 (2004) 330-345.

[150] S. Örn, H. Holbech, T.H. Madsen, L. Norrgren, G.I. Petersen, Gonad development and vitellogenin production in zebrafish (Danio rerio) exposed to ethinylestra- diol and methyltestosterone, Aquat. Toxicol. 65 (2003) 397-411.

[151] J.P. Nash, D.E. Kime, L.T.M. Van der Vem, P.W. Wester, F. Brion, G. Maack, P. Stahlschmidt-Allner, C.R. Tyler, Long-term exposure to environmental concentrations of the pharmaceutical ethynylestradiol causes reproductive failure in fish, Environ. Health Perspect. 112 (2004) 1725-1733.

[152] H. Xu, J. Yang, Y. Wang, Q. Jiang, H. Chen, H. Song, Exposure to 17aethynylestradiol impairs reproductive functions of both male and female zebrafish (Danio rerio), Aquat. Toxicol. 88 (2008) 1-8.

[153] Y. Katsu, A. Lange, H. Urushitani, R. Ichikawa, G.C. Paull, L.L. Cahill, S. Jobling, C.R. Tyler, T. Iguchi, Functional associations between two estrogen receptors, environmental estrogens, and sexual disruption in the roach (Rutilus rutilus), Environ. Sci. Technol. 41 (2007) 3368-3374.

[154] N. Hirai, A. Nanba, M. Koshio, T. Kondo, M. Morita, N. Tatarazako, Feminization of Japanese medaka (Oryzias latipes) exposed to 17 estradiol: Formation of testisova and sex-transformation during early-ontogeny, Aquat. Toxicol. 77 (2006) 78 86.

[155] I.J. Kang, H. Yokota, Y. Oshima, Y. Tsuruda, T. Yamaguchi, M. Maeda, N. Imada H. Tadokoro, T. Honjo, Effect of 17 estradiol on the reproduction of Japanese medaka (Oryzias latipes), Chemosphere 47 (2002) 71-80.

[156] E.F. Orlando, L.J. Guillette Jr., Sexual dimorphic responses in wildlife exposed to endocrine disrupting chemicals, Environ. Res. 104 (2007) 163-173.

[157] I. Gyllenhammar, L. Holm, R. Eklund, C. Berg, Reproductive toxicity in Xenopus tropicalis afeter developmental exposure to environmental concentrations of ethynylestradiol, Aquat. Toxicol. 91 (2009) 171-178.

[158] G.F. Vandenbergh, D. Adriaens, T. Verslycke, C.R. Janssen, Effects of 17aethinylestradiol on sexual development of the amphipod Hyalella azteca, Ecotoxicol. Environ. Saf. 54 (2003) 216-222.

[159] J.A. Jukosky, M.C. Watzin, J.C. Leiter, Elevated concentrations of ethinylestra- diol, 17 estradiol, and medroxyprogesterone have little effect on reproduc- tion and survival of Ceriodaphnia dubia, Bull. Environ. Contam. Toxicol. 81 (2008) 230 235 
[160] T. Isobe, H. Shiraishi, M. Yasuda, A. Shinoda, H. Suzuki, M. Morita, Determina- tion of estrogens and their conjugates in water using solid-phase extraction followed by liquid chromatography-tandem mass spectrometry, J. Chro- matogr. A 984 (2003) 195-202.

[161] S. Zuehlke, U. Duennbier, T. Heberer, Determination of estrogenic steroids in surface water and wastewater by liquid chromatography-electrospray tan- dem mass spectrometry, J. Sep. Sci. 28 (2005) 52-58.

[162] L. Yang, T. Luan, C. Lan, Solid-phase microextraction with on-fiber silyla- tion for simultaneous determinations of endocrine disrupting chemicals and steroid hormones by gas chromatography-mass spectrometry, J. Chromatogr. A 1104 (2006) 23-32.

[163] A. Laganà, A. Bacaloni, I. De Leva, A. Faberi, G. Fago, A. Marino, Analytical methodologies for determining the occurrence of endocrine disrupting chem- icals in sewage treatment plants and natural waters, Anal. Chim. Acta 501 (2004) 7988.

[164] E. Vulliet, L. Wiest, R. Baudot, M.-F. Grenier-Loustalot, Multi-residue analysis of steroids at sub-ng/L levels in surface and ground-waters using liquid chromatography coupled to tandem mass spectrometry, J. Chromatogr. A 1210 (2008) 84-91.

[165] P.D. Thacker, Pharmaceutical data elude researchers, Environ. Sci. Technol. 39 (2005) 193A-194A.

[166] M. Lürling, E. Sargant, I. Roessink, Life-history consequences for Daphnia pulex exposed to pharmaceutical carbamazepine, Environ. Toxicol. 21 (2006) 172180

[167] M. Oetken, G. Nentwig, D. Löffler, T. Ternes, J. Oehlmann, Effects of pharmaceu- ticals on aquatic invertebrates. Part I. The antiepileptic drug carbamazepine, Arch. Environ. Contam. Toxicol. 49 (2005) 353-361.

[168] F. Sacher, M. Ehmann, S. Gabriel, C. Graf, H.-J. Brauch, Pharmaceutical residues in the river Rhine - results of a one-decade monitoring programme, J. Environ. Monit. 10 (2008) 664-670.

[169] M. Leclercq, O. Mathieu, E. Gomez, C. Casellas, H. Fenet, D. Hillaire-Buys, Presence and fate of carbamazepine, oxcarbazepine, and seven of their metabolites at wastewater treatment plants, Arch. Environ. Contam. Toxicol. 56 (2009) 408415 .

[170] J.G. Nickerson, S.G. Dugan, G. Drouin, T.W. Moon, A putative 2 -adrenoceptor from the rainbow trout (Oncorhyncus mykiss). Molecular characteristion and pharmacology, Eur. J. Biochem. 268 (2001) 6465-6472.

[171] S. Haider, S.S.R. Baqri, Adrenoceptor antagonists reinitiate meiotic matu- ration in Clarias batrachus oocytes, Comp. Biochem. Physiol. A 126 (2000) 517-525.

[172] D.B. Huggett, B.W. Brooks, B. Peterson, C.M.Foran, D. Schlenk, Toxicity of select beta adrenergic receptor-blocking pharmaceuticals (B-Blockers) on aquatic organisms, Arch. Environ. Contam. Toxicol. 43 (2002) 229-235.

[173] D.G.J. Larsson, S. Fredriksson, E. Sandblom, N. Paxeus, M. Axelsson, Is heart rate in fish a sensitive indicator to evaluate acute effects of -blockers in surface water? Environ. Toxicol. Pharmacol. 22 (2006) 338-340.

[174] M.J. Winter, A.D. Lillicrap, J.E. Caunter, C. Schaffner, A.C. Alder, M. Ramil, T.A. Ternes, E. Giltrow, J.P. Sumpter, T.H. Hutchinson, Defining the chronic impacts of atenolol on embryo-larval development and reproduction in the fathead minnow (Pimephales promelas), Aquat. Toxicol. 86 (2008) 361-369.

[175] M. Cleuvers, Initial risk assessment for three -blockers found in the aquatic environment, Chemosphere 59 (2005) 199-205.

[176] E.M. Dzialowski, P.K. Turner, B.W. Brooks, Physiological and reproductive effects of beta adrenergic receptor antagonists in Daphnia magna, Arch. Env- iron. Contam. Toxicol. 50 (2006) 503-510.

[177] B.W. Brooks, C.M. Foran, S.M. Richards, J. Weston, P.K. Turner, J.K. Stanley, K.R. Solomon, M. Slattery, T.W. La Point, Aquatic ecotoxicology of fluoxetine, Toxicol. Lett. 142 (2003) 169-183.

[178] P.P. Fong, Zebra mussel spawning is induced in low concentrations of putative serotonin reuptake inhibitors, Biol. Bull. 194 (1998) 143-149.

[179] G. Nentwing, Effects of pharmaceuticals on aquatic invertebrates. Part II: the antidepressant drug fluoxetine, Arch. Environ. Contam. Toxicol. 52 (2007) 163170 .

[180] C.M. Foran, J. Weston, M. Slattery, B.W. Brooks, D.B. Huggett, Reproductive assessment of Japanese medaka (Oryzias latipes) following a four-week fluoxetine (SSRI) exposure, Arch. Environ. Contam. Toxicol. 46 (2004) 511-517.

[181] T.B. Henry, M.C. Black, Acute and chronic toxicity of fluoxetine (selective sero- tonin reuptake inhibitor) in western mosquitofish, Arch. Environ. Contam. Toxicol. 54 (2008) 325-330.

[182] E. Minagh, R. Hernan, K. O'Rourke, F.M. Lyng, M. Davoren, Aquatic ecotoxicity of the selective serotonin reuptake inhibitor sertraline hydrochloride in a battery of freshwater test species, Ecotoxicol. Environ. Saf. 72 (2009) 434-440.

[183] D.J. Johnson, H. Sanderson, R.A. Brain, C.J. Wilson, K.R. Solomon, Toxicity and hazard of selective serotonin reuptake inhibitor antidepressants fluoxe- tine, fluvoxamine, and sertraline to algae, Ecotoxicol. Environ. Saf. 67 (2007) 128-139.

[184] B.W. Brooks, P.K. Turner, J.K. Stanley, J.J. Weston, E.A. Glidewell, C.M. Foran, M. Slattery, T.W. La Point, D.B. Huggett, Waterborne and sediment toxicity of fluoxetine to select organisms, Chemosphere 52 (2003) $135-142$.

[185] V.L. Cunningham, D.J.C. Constable, R.E. Hannah, Environmental risk assess- ment of paroxetine, Environ. Sci. Technol. 38 (2004) 3351-3359.

[186] T. Vasskog, U. Berger, P.-J. Samuelsen, R. Kallenborn, E. Jensen, Selective sero-tonin reuptake inhibitors in sewage influents and effluents from Troms $\varnothing$, Norway, J. Chromatogr. A 1115 (2006) 187-195.

[187] T. Vasskog, T. Anderssen, S. Pedersen-Bjergaard, R. Kallenborn, E. Jensen, Occurrence of selective serotonin reuptake inhibitors in sewage and receiv- ing waters at Spitsbergen and in Norway, J. Chromatogr. A 1185 (2008)194- 205.

[188] A. Lajeunesse, C. Gagnon, S. Sauvé, Determination of basic antidepressants and thei $\mathrm{N}$-desmethyl metabolites in raw sewage and wastewater using solid- phase extraction and liquid chromatography-tandem mass, Anal. Chem. 80 (2008) $5325-5333$.

[189] A.C. Johnson, M.D. Jürgens, R.J. Williams, K. Kümmerer, A. Kortenkamp, J.P Sumpter, Do cytotoxic chemotherapy drugs discharged into rivers pose a risk to the environment and human health? An overview and UK case study, J. Hydrol. 348 (2008) 167-175.

[190] M. Grung, T. Källqvist, S. Sakshaug, S. Skurtveit, K.V. Thomas, Environmen- ta assessment of Norwegian priority pharmaceuticals based on the EMEA guideline, Ecotoxicol. Environ. Saf. 71 (2008) 328-340.

[191] M. DellaGreca, M.R. Iesce, M. Isidori, A. Nardelli, L. Previtera, M. Rubino, Phototransformation products of tamoxifen by sunlight in water. Toxicity of the drug and its derivatives on aquatic organisms, Chemosphere 67 (2007) 1933-1939.

[192] T. Steger-Hartmann, K. Kümmerer, A. Hartmann, Biological degradation of cyclophosphamide and its occurrence in sewage water, Ecotoxicol. Environ. Saf. 36 (1997) 174-179.

[193] I.J. Buerge, H.-R. Buser, T. Poiger, M.D. Müller, Occurrence and fate of the cytostatic drugs cyclophosphamide and ifosfamide in wastewater and surface waters, Environ. Sci. Technol. 40 (2006) 7242-7250.

[194] J.L. Zhou, Z.L. Zhang, E. Banks, D. Grover, J.Q. Jiang, Pharmaceutical residues in wastewater treatment works effluents and their impact on receiving river water, J. Hazard. Mater. 166 (2009) 655-661.

[195] S. Pérez, D. Barceló, Fate and occurrence of X-ray contrast media in the environment, Anal. Bioanal. Chem. 387 (2007) 1235-1246.

[196] T. Steger-Hartmann, R. Länge, H. Schweinfurth, M. Tschampel, I. Rehmann, Investigations into the environmental fate and effects of iopromide (ultrav- ist), a widely used iodinated X-ray contrast medium, Water Res. 36 (2002) 266-274.

[197] T. Steger-Hartmann, R. Länge, H. Schweinfurth, Environmental risk assess- ment for the widely used iodinated X-ray contrast agent iopromide (Ultravist), Ecotoxicol. Environ. Saf. 42 (1999) 274-281.

[198] M. Carballa, F. Omil, J.M. Lema, M. Llompart, C. Garcia-Jares, I. Rodríguez, M Gómez, T. Ternes, Behavior of pharmaceuticals, cosmetics and hormones in a sewage treatment plant, Water Res. 38 (2004) 2918-2926.

[199] T.A. Ternes, R. Hirsch, Occurrence and behavior of X-ray contrast media in sewage facilities and the aquatic environment, Environ. Sci. Technol. 34 (2000) $2741-2748$.

[200] R.A. Trenholm, B.J. Vanderford, J.C. Holady, D.J. Rexing, S.A. Snyder, Broad range analysis of endocrine disruptors and pharmaceuticals using gas chromatography and liquid chromatography tandem mass spectrometry, Chemosphere 65 (2006) 1990-1998.

[201] F. Busetti, K.L. Linge, J.W. Blythe, A. Heitz, Rapid analysis of iodinated X- ray contrast media in secondary and tertiary treated wastewater by direct injection liquid-chromatography-tandem mass spectrometry, J.Chromatogr. A 1213 (2008) 200-208.

[202] W. Seitz, W.H. Weber, J.-Q. Jiang, B.J. Lloyd, M. Maier, D. Maier, W. Schulz, Monitoring of iodinated X-ray contrast media in surface water, Chemosphere 64 (2006) 1318-1324.

[203] A. Putschew, S. Wischnack, M. Jekel, Occurrence of triiodinated X-ray con- trast agents in the aquatic environment, Sci. Total Environ. 255 (2000) 129-134.

[204] R. Hirsch, T.A. Ternes, A. Lindart, K. Haberer, R.-D. Wilken, A sensitive method for the determination of iodine containing diagnostic agents in aque- ous matrices using LC-electrospray-tandem-MS detection, Fresenius J. Anal. Chem. 366 (2000) 835-841.

[205] M. Farré, S. Pérez, L. Kantiani, D. Barceló, Fate and toxicity of emerging pollutants, their metabolites and transformation products in the aquatic environment, Trends Anal. Chem. 27 (2008) 991-1007.

[206] M.J. García-Galán, M.S. Díaz-Cruz, D. Barceló, Identification and determination of metabolites and degradation products of sulfonamide antibiotics, Trends Anal. Chem. 27 (2008) 1008-1022.

[207] B. Quinn, F. Gagné, C. Blaise, Evaluation of the acute, chronic and terato- genic effects of a mixture of eleven pharmaceuticals on the cnidarian, Hydra attenuata, Sci. Total Environ. 407 (2009) 1072-1079.

[208] U. Borgmann, D.T. Bennie, A.L. Ball, V. Palabrica, Effect of a mixture of seven pharmaceuticals on Hyalella azteca over multiple generations, Chemosphere 66 (2007) $1278-1283$.

[209] J.L. Parrott, D.T. Bennie, Life-cycle exposure of fathead minnows to a mixture of six common pharmaceuticals and triclosan, J. Toxicol. Environ. Health A 72 (2009) 633-641.

[210] Comission Directive 92/18/EEC, Modifying the Annex to Council Directive 81/852/EEC on the Approximation of the Laws of Member States Relating to Analytical, Pharmacotoxicological and Clinical Standards and Protocols in Respect of the Testing of Veterinary Medicinal Products, 1992.

[211] EMEA, Note for Guidance: Environmental Risk Assessment for Veteri- nary Medicinal Products Other Than GMO-Containing and Immunological Products, The European Agency for the Evaluation of Medicinal Prod- ucts: Veterinary Medicines Evaluation Unit, EMEA/CVMP/055/96-FINAL, 1998.

[212] EudraLex - Volume 1 - Pharmaceutical Legislation Medicinal Products for Human Use, On line at: http://ec.europa.eu/enterprise/pharmaceuticals/ eudralex/voll en.htm (accessed in 16 February 2009). 
[213] EMEA, Guideline on the Environmental Risk Assessment of Medicinal Products for Human Use, The European Agency for the Evaluation of Medicinal Products: Committee for Medicinal Products for Human Use, EMEA/CHMP/SWP/4447/00, 2006

[214] FDA, Guidance for Industry: Environmental Assessment of Human Drug and Biologics Applications, Food and Drug Administration (Center for Drug Evaluation and Research), CMC 6, Revision 1,1998.
[215] EMEA, Guideline on Environmental Impact Assessment (EIAs) for Veteri- nary Medicinal Products-Phase I, The European Agency for the Evaluation of Medicinal Products: Committee for Medicinal Products for Veterinary Use, CVMP/VICH/592/98-FINAL, 2000

[216] EMEA, Guideline on Environmental Impact Assessment for Veterinary Medicinal Products-Phase II, The European Agency for the Evaluation of Medicinal Products: Committee for Medicinal Products for Veterinary Use, CVMP/VICH/790/03-FINAL, 2005 . 